\title{
Toxicity of \\ Polyelectrolyte Flocculants to Rainbow Trout
}


Digitized by the Internet Archive in 2015

https://archive.org/details/toxicityofpolyel00albe 
TOXICITY OF POLYELECTROLYTE FLOCCULANTS

TO RAINBOW TROUT

AQUATIC BIOLOGY GROUP

ANIMAL SCIENCES WING

ALBERTA ENVIRONMENTAL CENTRE

FEBRUARY 24, 1987 
This report may be cited as: Toxicity of Polyelectrolyte Flocculants to Rainbow Trout, Vegreville, Alberta, Alberta Environmental Centre. 86 p. 1987. AECV87-R3. 
TABLE OF CONTENTS .......................

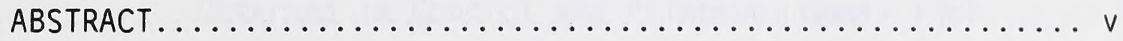

PROJECT TEAM..............................

ACKNOWLEDGEMENTS .........................

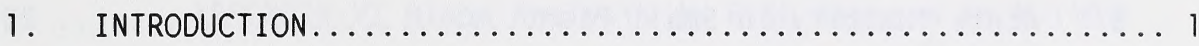

1.1 Flocculant Performance................... 1

1.2 Study Area.......................... 3

1.3 Flocculating Agents Under Investigation.......... 6

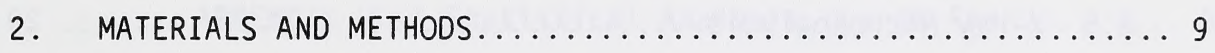

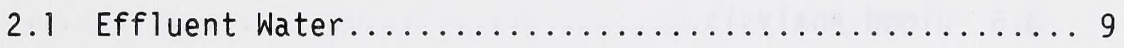

2.2 Source and Specifications of Test Fish and Their

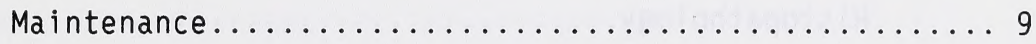

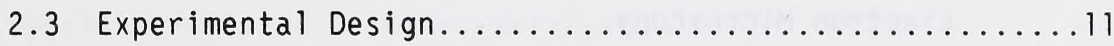

A. Acute Toxicity in Small Fish...................

B. Subacute Toxicity in Large Fish..............13

2.4 Histopathology........................ 14

2.5 Electron Microscopy..................... 44

2.6 X-ray Microanalysis.................... 5

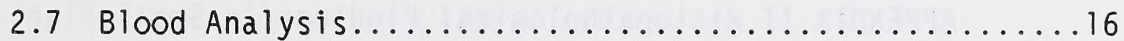


TABLE OF CONTENTS (Continued)

PAGE

2.8 Statistical Analysis............................ 18

A. Small Fish.......................... 18

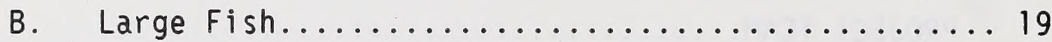

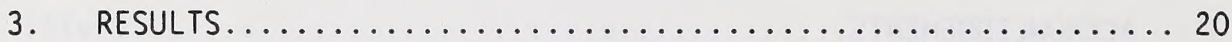

3.1 Acute Toxicity in Small Fish................... 20

3.2 Subacute Toxicity in Large Fish................. 22

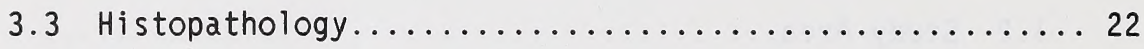

3.4 Electron Microscopy........................ 24

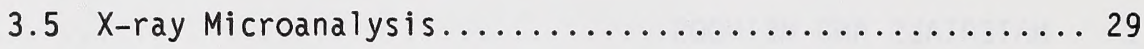

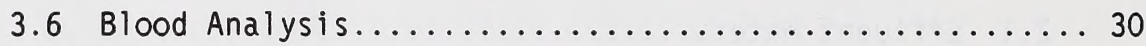

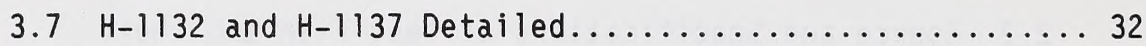

Histopathology.......................... 32

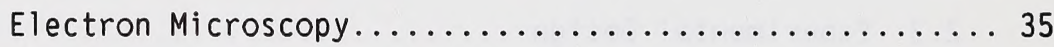

Blood Analysis............................ 41

4. DISCUSSION AND CONCLUSIONS.................... 41

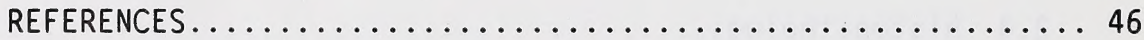

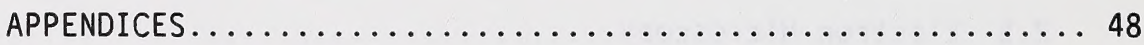

APPENDIX I Micrographs.................... 48

APPENDIX II Histopathological Findings in Small Fish... 65 


\section{TABLE OF CONTENTS (Continued)}

PAGE

APPENDIX III Total Number of Gill and Skin Lesions

Observed in Control and Principal Small Fish..... 77

APPENDIX IV Statistical Analysis, Small Fish......... 80

APPENDIX V Histological Lesions Seen in Large Fish.... 81

APPENDIX VI Blood Analysis in Fish Exposed to $\mathrm{H}-1137$

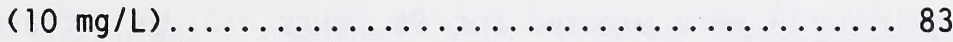

APPENDIX VII Blood Analysis in Fish Exposed to $\mathrm{H}-1137$

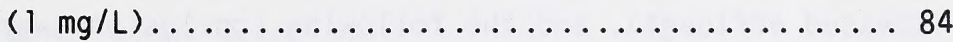

APPENDIX VIII Statistical Analysis, Large Fish........ 85

(iv) 


\section{ABSTRACT}

The purpose of this study was to describe the acute and subacute toxic effects to fish of six Hercofloc( flocculants (H) considered for use in the coal mining industry in Alberta. These flocculants are acrylamide-based polymers and possess either cationic (H-1132, H-1137), anionic $(H-1121, H-1123, H-1142)$ or non-ionic $(H-1110)$ charge.

In the acute study, groups of small rainbow trout (Salmo gairdneri) were exposed for 96 hours ( $h$ ) to different concentrations of the flocculants $(1-150 \mathrm{mg} / \mathrm{L})$ in municipal water or mine wastewater (treated effluent), and the following conclusions were reached:

1. The $96 \mathrm{~h} L C_{50}$ of nonionic $H-1110$, and anionic agents $H-1121$ and $\mathrm{H}-1142$ were $>150 \mathrm{mg} / \mathrm{L}$ whether they were mixed with municipal water or treated effluent.

2. The $96 \mathrm{~h} L C_{50}$ of anionic $\mathrm{H}-1123$ was $>150 \mathrm{mg} / \mathrm{L}$ when combined with municipal water, and it caused $100 \%$ mortality when mixed with mine treated effluent at concentrations of 10 and $50 \mathrm{mg} / \mathrm{L}$ but caused no mortality at 100 and $150 \mathrm{mg} / \mathrm{L}$.

3. H-1132 and $H-1137$ (both cationic) were not toxic when combined with treated effluent; however, their $96 \mathrm{~h}$ LC $_{50}$ 's were 50-100 and $10-50 \mathrm{mg} / \mathrm{L}$ respectively when mixed with treated municipal water.

هHercofloc flocculants are produced by Hercules Incorporated (Wilmington, Delware). 
4. The gills and skin were the target organs of the flocculants. Histopathological lesions in these tissues varied from mild to severe.

5. Treated effluent alone (control) produced more severe gill lesions than when combined with Hercoflocs.

6. Treated effluent alone produced no skin lesions; however, its combination with Hercoflocs induced such lesions.

7. Hercofloc flocculants combined with treated municipal water caused a higher incidence of gill and skin lesions than treated municipal water alone (control).

8. The toxic effect of Hercofloc depends on its free availability in the medium. Hercoflocs are more toxic when mixed with municipal water than with treated effluent.

In the subacute toxicity study, groups of large rainbow trout were exposed to flocculants at or below the $96 \mathrm{~h} \quad \mathrm{LC}_{50}$ concentrations for small rainbow trout. Half of the fish were necropsied at 96 hours; the remaining fish were left in treated municipal water for another 96 hours then submitted for necropsy.

From this study, the following conclusions could be made:

1. No significant histopathological or clinicopathological findings were seen in fish exposed to the nonionic and anionic agents $(\mathrm{H}-1110, \mathrm{H}-1121, \mathrm{H}-1123$ and $\mathrm{H}-1142)$ at $150 \mathrm{mg} / \mathrm{L}$.

2. Electron microscopy findings in the gills indicated that the above flocculants enhanced epithelial cell turnover with increased cellular debris in the subepithelium. 
3. Hercofloc 1137 (cationic) was lethal for $100 \%$ of large fish at 10 and $1 \mathrm{mg} / \mathrm{L}$. Hercofloc 1132 (cationic) was lethal for $100 \%$ of large fish at $50 \mathrm{mg} / \mathrm{L}$.

4. H-1137 and H-1132 produced acute severe necrosis of gill epithelium; this was confirmed by light and electron microscopy.

5. The above morphological alterations were associated with significant loss of blood electrolytes and an increase in blood glucose and $\mathrm{CO}_{2}$. The latter increase contributed to lowering blood $\mathrm{pH}$.

SUMMARY STATEMENT: From the wide range of observed effects in both studies, it was concluded that Hercofloc-1132 and Hercofloc-1137 in municipal water were lethal for $100 \%$ of large rainbow trout at $50 \mathrm{mg} / \mathrm{L}$ and $1 \mathrm{mg} / \mathrm{L}$ concentrations respectively. The same flocculants were less toxic to small rainbow trout in municipal water $\left(L_{5} C_{5}\right.$ 's were 50-100 and $10-50 \mathrm{mg} / \mathrm{L}$ respectively); however, combination of each flocculant with treated mine effluent produced no remarkable toxicity to small rainbow trout. Hercofloc-1110, Hercofloc-1121, Hercofloc-1123 and Hercofloc-1142 were safe for use. 


\section{PROJECT TEAM}

Mudher Albassam

Rakesh Bhatnagar

Clare Gulayets

Rosemary Harris

Marlene Lefebvre

Elizabeth McGuinness

Leonard E. Lillie
Ahmed Mutalib

Marja Morwood-Clark

James Moore*

Arvind Sharma

Kevin Smiley

Kathleen Wilson

*Person to whom correspondence should be addressed.

\section{ACKNOWLEDGEMENTS}

We would like to acknowledge the assistance of the Director (Standards and Approvals Division, Alberta Environment) and Walter M. Nahulak (Standards and Approvals Division) in conducting this study. We are also grateful to staff from the Luscar Mine (Curtis Brinker, Rick Ferster) for gaining access to the site. This work was initiated at the request of Alberta Environment (Standards and Approvals Division). 


\section{INTRODUCTION}

Flocculants are widely used in the coal mining industry to remove suspended solids from wastewater. They may be used singly or in different combinations to meet various operating conditions. Although many of these flocculants have been extensively tested by suppliers, some products are relatively new and sufficient data are not available to assess their toxicity. In most cases, little information is available on the environmental fate of flocculants and concomitant effects on fish.

\subsection{Flocculant Performance}

If a flocculant performs correctly, it will coalesce with colloids to form large particles and then sink from the water column. This means that fish would not be exposed to flocculants that work correctly. If the flocculant does not bind with colloids, the flocculant will remain in the water column and possibly be transported to receiving waters. Several variables influence the performance of synthetic flocculants, including: molecular weight, molecular linearity, ionic character and level and distribution of ionic functionality. In general, the effectiveness of a flocculant increases with its molecular weight and linearity and the nature of the material being tested. The longer the molecule, the more chance it has to contact colloids (Fig. 1). A short molecule, or one which is highly branched, covers less bulk water, thereby reducing the change of coalescing with colloids. In a waste treatment pond with 


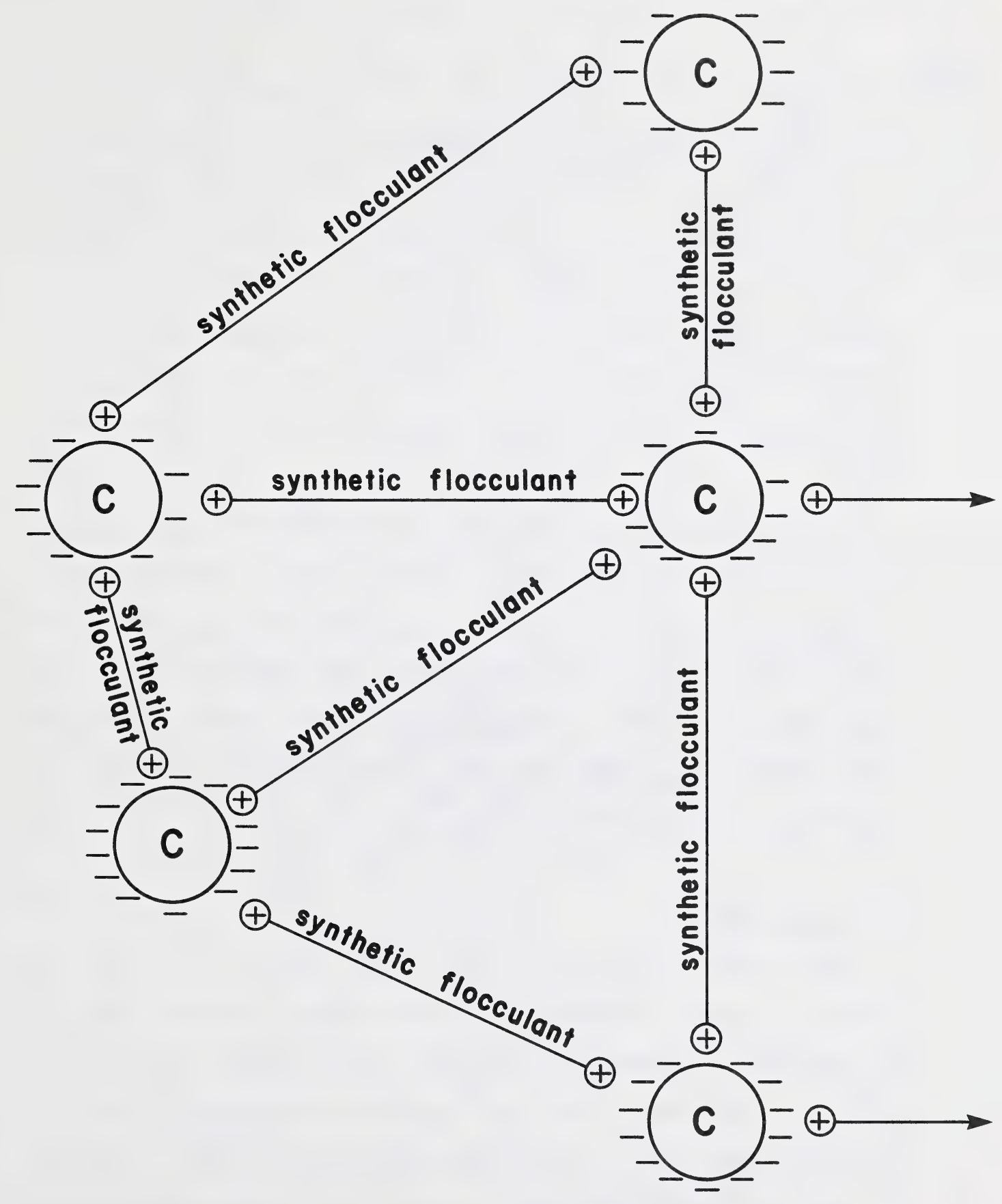

FIGURE I. BINDING OF MOLECULES OF A SYNTHETIC FLOCCULANT WITH COLLOIDS (C) 
high suspended solids, there will be a variable charge on colloids and molecules. The nature of these charges may change in the presence of heavy metals, other contaminants, water hardness and with a change in pH. The colloids with a similar charge will remain in the water column and it therefore becomes necessary to use flocculants with an opposite charge to coalesce these particles. Since the charge on the suspended load entering treatment ponds may change with time, it may be necessary to alter the type of flocculant used over the life of the pond.

Relatively little is known about the environmental fate processes that affect flocculants in natural receiving waters. Because of their charge, it is likely that sorption to suspended particles would be the dominant fate process. This would likely reduce toxicity to fish and other aquatic organisms. However, in water with a low suspended solid load, binding to particles would be lower, thereby increasing the possibility of toxic effects on fish.

\subsection{Study Area}

Coal Valley Mine operated by Luscar Sterco (1977) Ltd. is situated in western Alberta about $100 \mathrm{~km}$ southwest of Edson (Fig. 2). The operation, located along the banks of the Lovett River, uses a series of impoundments for the treatment of wastewater (Fig. 3). Flocculants are added to these impoundments and the water is decanted to the Lovett River. In 1982, the quality of effluent decreased due in part to mine expansion through new geologic materials. There was a 


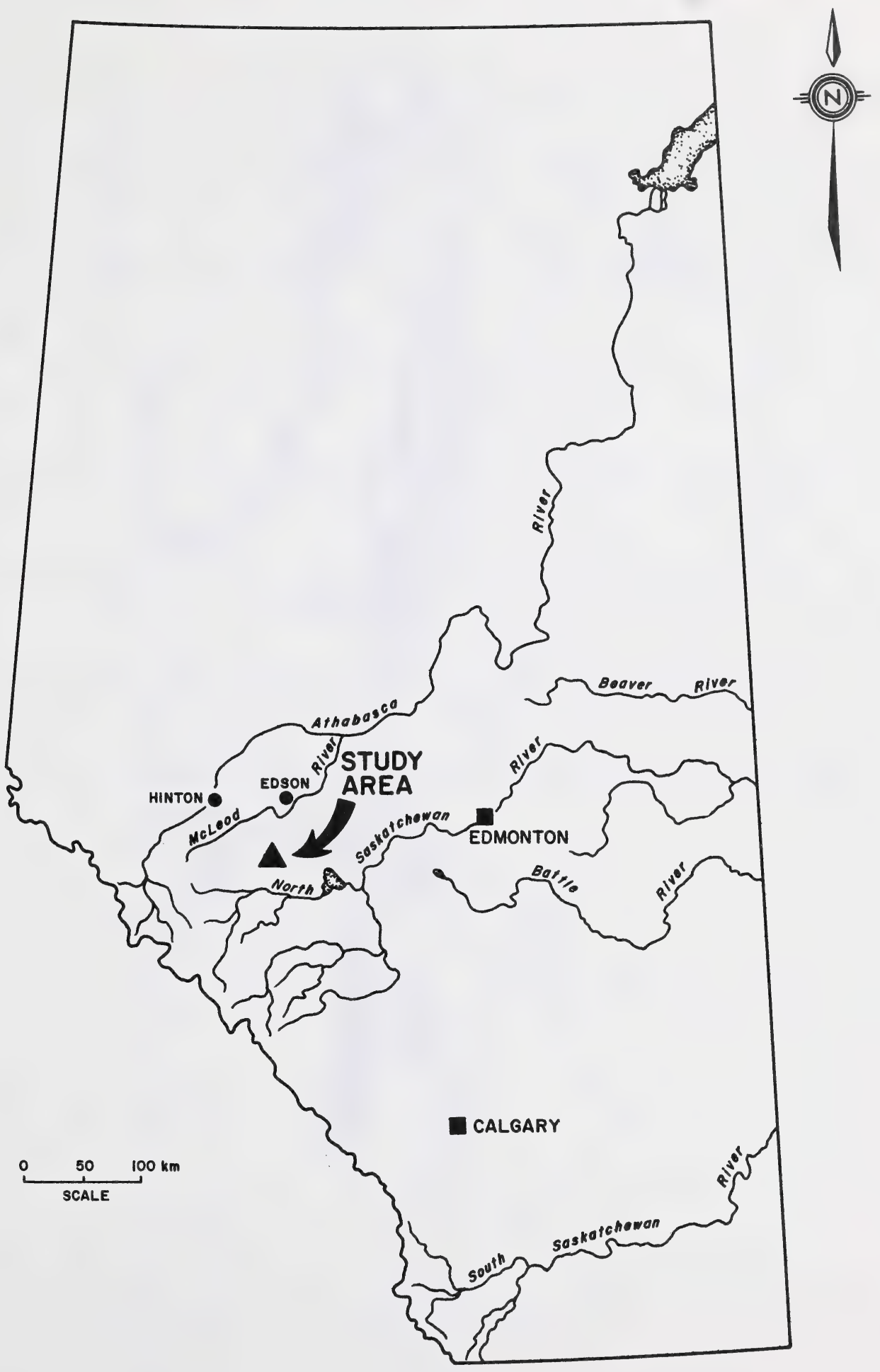

FIGURE 2. MAP OF ALBERTA SHOWING LOCATION OF STUDY AREA 


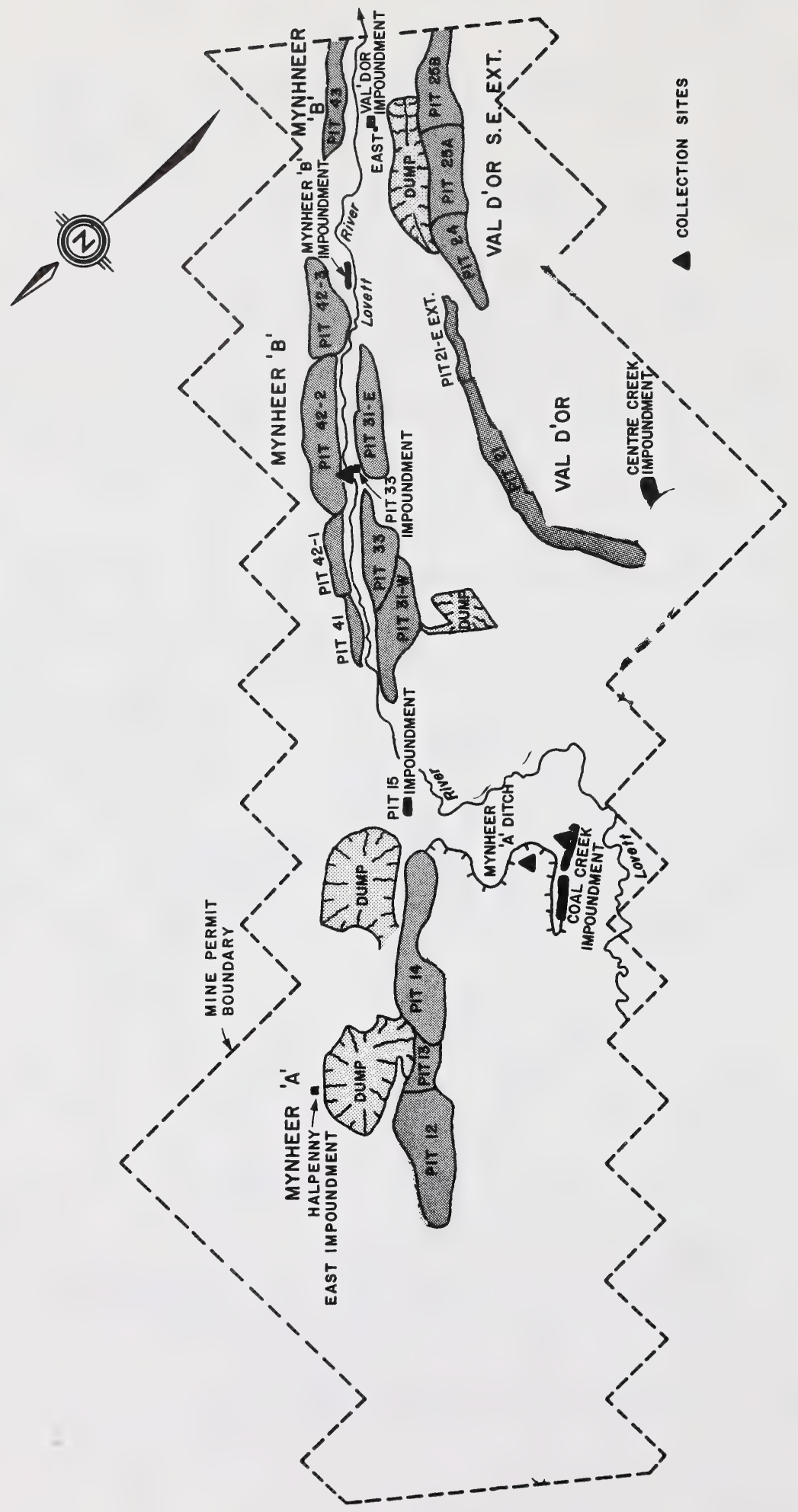

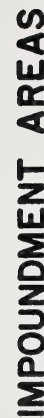

点

呈

$\frac{n}{a}$

岁

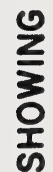

崖

岌

옹

$m$

峁 
concomitant decrease in effectiveness of the flocculants then used, and, accordingly, the mine sought more effective flocculants. Included in the new group were Hercofloc flocculants plus five other agents that were potentially suited to the mine's operation: Ferric Sulfate, Anionic 8184, Cationic 8852, Cationic $577 \mathrm{C}$ and Cationic LT31. Staff from the Alberta Environmental Centre were then asked by Standards and Approvals Division (Alberta Environment) to determine the toxicity of these compounds to fish. We found that Anionic 8184 and Ferric Sulfate were not acutely toxic, whereas the remaining flocculants (Cationic 577C, Cationic 8852 and Cationic LT31) had $96 \mathrm{~h}$ $L C_{50}$ 's of $40-100 \mathrm{mg} / \mathrm{L}$ (AEC, 1985). In fish exposed to toxic levels of the cationic flocculants, there was necrosis and sloughing of the gill epithelia, oral mucosa and skin. Concentrations of 40-100 mg/L are generally not applied to wastewaters in Alberta's coal mining industry.

\subsection{Flocculating Agents Under Investigation}

Hercules Incorporated of Wilmington (Delaware) produces a number of flocculant gels within the Hercofloc series. Those under investigation here were:
a. Hercofloc 1110
non-ionic
b. Hercofloc 1121
low anionic
c. Hercofloc 2234
medium anionic
d. Hercofloc 1132
low cationic
e. Hercofloc 1137
medium cationic
f. Hercofloc 1142
low anionic 
These flocculants are acrylamide-based copolymers with molecular weights in excess of 10 million. They have a specific gravity of approximately 1.1 , and a freezing point of $-17^{\circ} \mathrm{C}$. The anionic and non-ionic flocculants have a pH of $8.5-10$ (in a $1 \%$ solution of distilled water) whereas the $\mathrm{pH}$ range of the cationic flocculants is $4-5$.

Acrylamide-based polymers (PAM) exhibit the generalized formula shown in Figure 4. They are manufactured by using a number of different processes including aqueous solution, polymerization, dispersed phase polymerization (also known as suspension and inverse emulsion polymerization) and precipitation polymerization (also referred to as mixed solvent polymerization).

In dispersed phase polymerization, droplets of a concentrated aqueous monomer solution ( $>40 \%$ monomer) are dispersed in an organic medium (for example, xylene or other hydrocarbon). This results in a system with relatively low bulk viscosity while still maintaining aqueous polymerization conditions suitable for the formation of high molecular weight polymers. Aqueous solution polymerization using low solid concentrations is also still commonly used but is gradually being replaced by a number of related processes such as continuous belt and photopolymerization. The use of cobalt-60 radiation instead of chemical catalysts permits the synthesis of PAM in gel form (Hercofloc).

Hydrolyzed polyacrylamide, as well as homopoly acrylic acid, are the main anionic flocculants on the market. PAM is readily hydrolyzed 


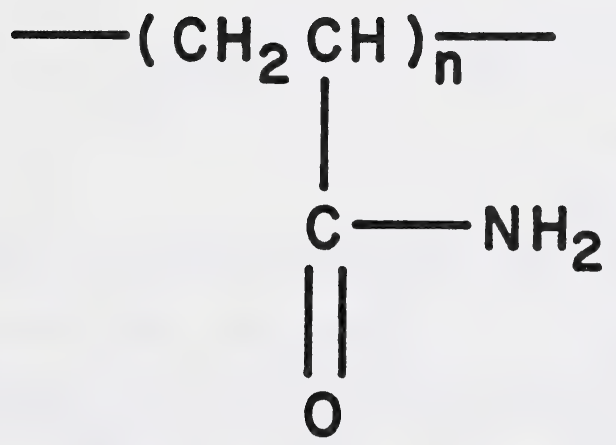

Figure 4. Generalized formula of a polyacrylamide flocculant. 
with either sodium hydroxide or sodium carbonate in an aqueous medium. Initially, the rate of hydrolysis is relatively rapid with conversion of up to $50 \%$ of the amide groups. Copolymerization of acrylic acid with acrylamide may produce an entire range of anionicity. Although the carboxyl grouping of a compound exhibits relatively strong acid properties, the extent of ionization is a function of $\mathrm{pH}$ in acidic substrates.

\section{MATERIALS AND METHODS}

\subsection{Effluent Water}

Treated effluent water was collected from the mine prior to its discharge to the waste treatment pond. The effluent collected at this stage did not contain any flocculant introduced by the mine. The effluent was transported to our laboratory in 25 gallon drums lined with inert plastic. The samples were stored in the dark at $2-4^{\circ} \mathrm{C}$ prior to use. Total suspended solids and other physico-chemical parameters of the treated effluent water were not determined.

\subsection{Source and Specifications of Test Fish and Their Maintenance}

Small and large rainbow trout Salmo gairdneri were used for this study. Small fish were 2.5-6 cm in length and 0.3-3 $\mathrm{g}$ in wet weight. These fish were obtained as eggs from the Mount Lassen Trout Farm (California) and reared in the laboratories of the Environmental Protection Service, Edmonton. Table 1 gives the physical and chemical 
characteristics of water used in egg rearing. Fry were transported to the Alberta Environmental Centre and allowed to acclimate at least two weeks prior to experimentation. Table 2 gives physical and chemical characteristics of water used to rear trout fry; all conditions fall within the range normally used for fish maintenance (McGuinness, 1982, Table 1).

Table 1. Physico-chemical characteristics of water used to rear rainbow trout eggs. Concentrations expressed as average ( $\mathrm{mg} / \mathrm{L}$ ) during rearing period.

\begin{tabular}{lcll} 
Temperature $\left({ }^{\circ} \mathrm{C}\right)$ & $11.5-12.5$ & Calcium & 26 \\
Dissolved Oxygen & $8.4-8.9$ & Chromium & $<0.05$ \\
pH & $7.6-7.9$ & Copper & $<0.02$ \\
Chloride & 3.4 & Iron & $<0.02$ \\
Total hardness & 99 & Lead & $<0.0005$ \\
Calcium hardness & 66 & Magnesium & 81 \\
Magnesium hardness & 33 & Nickel & $<0.008$ \\
Total alkalinity (as $\left.\mathrm{CaCO}_{3}\right)$ & 34 & Potassium & 0.08 \\
Sulfate & 68 & Sodium & 3.9 \\
Conductivity $(\mu \mathrm{S} / \mathrm{cm})$ & 210 & Zinc & 0.03 \\
& & & \\
\hline
\end{tabular}

Table 2. Physico-chemical characteristics of water used to rear rainbow trout fry. Concentrations expressed as $\mathrm{mg} / \mathrm{L}$.

$\begin{array}{lclc}\text { Temperature }\left({ }^{\circ} \mathrm{C}\right) & 12.5-15.0 & \text { Calcium } & 12-15 \\ \text { Dissolved Oxygen } & 8.0-9.5 & \text { Iron } & <0.02 \\ \text { pH } & 7.0-7.9 & \text { Magnesium } & 5 \\ \text { Chloride } & 2 & \text { Potassium } & 0.3-0.4 \\ \text { Total hardness } & 51-58 & \text { Sodium } & 3-13 \\ \left.\text { Total alkalinity (as } \mathrm{CaCO}_{3}\right) & 42-49 & \text { Silica } & 1.4-1.5 \\ \text { Sulfate } & 26-28 & \text { Nitrite } & <0.05 \\ \text { Conductivity }(\mu \mathrm{S} / \mathrm{cm}) & 136-154 & & \end{array}$


Large fish were $27 \pm 3.28 \mathrm{~cm}$ in length and $267.9 \pm 88 \mathrm{~g}$ in weight. They were obtained from Trout Springs Ltd. in Calgary. These fish were allowed to acclimate in the laboratory for three weeks prior to experimentation. Table 3 gives physico-chemical conditions of treated municipal water to maintain these fish.

Table 3. Physico-chemical characteristics of water used to maintain the large rainbow trout.*

Dissolved Oxygen

$9.03 \mathrm{ppm}(6.8-10.6)$

$\mathrm{pH}$

$7.63(7.28-7.95)$

Temperature

$12.1^{\circ} \mathrm{C}(7.0-15.0)$

Conductivity

$197 \mu \mathrm{s} / \mathrm{cm}(152-260)$

*Values are based on daily measurements from January 26, 1984 to May $24,1984$.

\subsection{Experimental Design}

A. Acute Toxicity in Small Fish

Toxicity was initially measured using $96 \mathrm{~h}$ lethal concentration (LC) tests. All experiments were conducted at $15 \pm 1^{\circ} \mathrm{C}$, a temperature which minimized microbial growth in fish holding tanks while still permitting rapid growth of experimental fish. A number of different concentrations of flocculants were examined (Table 4). Dosages were calculated volumetrically using the specific gravity of each 
Table 4. Concentration of flocculants used in different dilution water to determine acute toxicity.

\begin{tabular}{rr}
\hline Compound & DILUTION WATER - TREATED MUNICIPAL WATER \\
Applied Dosage $(\mathrm{mg} / \mathrm{L})$
\end{tabular}

Hercofloc 1110

Hercofloc 1121

Hercofloc 1123

Hercofloc 1132

Hercofloc 1137

Hercofloc 1142

$0,1,10,50,100,150$

$0,1,10,50,100,150$

$0,1,10,50,100,150$

$0,1,10,50,100,150$

$0,1,10,50,100,150$

$0,1,10,50,100,150$

Compound

DILUTION WATER - MINE EFFLUENT

Applied Dosage (mg/L)

Hercofloc 1110

Hercofloc 1121

Hercofloc 1123

Hercofloc 1132

Hercofloc 1137

Hercofloc 1142

$0,1,10,50,100,150$

$0,1,10,50,100,150$

$0,1,10,50,100,150$

$0,1,10,50,100,150$

$0,1,10,50,100,150$

$0,1,10,50,100,150$

compound. Each flocculant came from the supplier as a $3 \%$ solution of the active ingredient; thus reported dosages are based on this $3 \%$ solution. Each test procedure followed a number of steps:

1. Six polyethylene bags were rinsed three times with dilution water to remove potential contaminants, and were then checked for holes.

2. The dilution water was poured using a clean polyethylene pail reserved for that purpose. Dilution volume was either $20 \mathrm{~L}$ or $40 \mathrm{~L}$.

3. The temperature, $\mathrm{pH}$, conductivity and dissolved oxygen level of each chamber was determined. 
4. Ten fish were used in each test chamber; these fish were not fed throughout the experiment or for 48 hours prior to the start of the experiment.

5. Observations for potential mortality were made at the start of the test and at 15 minutes, 30 minutes, 1 hour, 2 hours, 4 hours, 8 hours, 24 hours, 48 hours, 72 hours and 96 hours. Fish were considered dead when there was no respiratory or other movement, and no response to gentle prodding.

6. Control chambers using either treated municipal water or effluent, were also maintained throughout the $96 \mathrm{~h}$ experimental period.

B. Subacute Toxicity in Large Fish

Since preliminary data obtained for acute toxicity tests indicated effects of the flocculants on the gills, it was anticipated that oxygen transfer to the bloodstream would be inhibited. Accordingly, subacute tests were conducted to determine the concentration of gases and electrolytes in fish blood.

A total of 10-12 large rainbow trout were initially exposed to a combination of flocculant and treated municipal water for $96 \mathrm{~h}$ after which 5-6 fish were submitted for histopathological and hematological studies. Treated municipal water was then introduced to the exposure chamber resulting in the displacement of any dissolved flocculant within $2 \mathrm{~h}$. After this flushing, the remaining fish were left in the 
treated municipal water for another $96 \mathrm{~h}$. Tissues and blood were evaluated for histopathological and hematological changes at the end of this period. Because these larger fish required a large amount of dilution water to maintain standard experimental conditions, experiments were conducted at only 1 or 2 concentrations ( $=96 \mathrm{~h}$ $L_{50}$ of small fish).

\subsection{Histopathology}

Histopathological examination was carried out as part of both acute and subacute studies. Five fish (dead and/or alive) were collected from each concentration for this purpose. Small fish were first slit open at their abdomens and then placed immediately in the fixative. Large fish were routinely necropsied and appropriate tissues were collected and fixed in Bouin's solution for 24 hours. Tissues were then kept in $70 \%$ alcohol until trimming. Tissues were routinely processed, sectioned at 5-6 $\mu \mathrm{m}$ and stained with hematoxylin and eosin. Gill, heart, oral cavity, eye, brain, liver, stomach, pyloric ceca, intestine, pancreas, spleen, kidney, gonads, skin and muscle were examined in each fish.

\subsection{Electron Microscopy}

Electron microscopy was carried out on the large fish only. One gill arch was removed from one fish at each time period, fixed in Millonig's buffered $1 \%$ osomium tetroxide for an hour. It was then dehydrated and embedded in epoxy resin. Thick and thin sections were 
Table 5. Concentrations of different flocculants used to determine subacute toxicity.

\section{Compound}

Hercofloc 1110

Hercofloc 1121

Hercofloc 1123

Hercofloc 1132

Hercofloc 1137

Hercofloc 1142

Applied Dosage (mg/L)

prepared using a Reichert-Jung microtome. Glass knives were used for thick sectioning and a diamond knife for thin sectioning. Thick sections were stained with methylene blue-azur II and were examined by light microscopy. Thin sections were stained with aqueous uranyl acetate and lead citrate and then examined with a Hitachi 600 electron microscope operating at $75 \mathrm{kv}$.

\subsection{X-ray Microanalysis}

Electron microscope (EM) studies were conducted primarily to evaluate the effects of flocculants on the morphology of gill tissue and to trace ensuing accumulation of some specific elements of the flocculants at the ultrastructural level. Before embarking on the ultrastructural studies, it was essential to characterize the elemental composition of the flocculants.

Elemental characterization of the flocculants: $10 \mathrm{~mL}$ of the flocculants (No. $1137,1142,1110,1121,1123$ and 1132) were freeze- 
dried using a Labconco freeze dryer 18. Flaky freeze-dried material was stored in a desiccator and removed just before EM examination.

Samples of freeze-dried flocculant were placed on a $3.05 \mathrm{~mm}$ diameter carbon and formvar-coated copper grid. The samples were examined with the Scanning Transmission Electron Microscopy (STEM) mode and analyzed by the qualitative Energy Dispersive X-ray (EDX) analysis procedure. An electron probe of 10 to $100 \mathrm{~nm}$ was placed at 4 random locations on the dark homogenous flocculant materials (as it appeared in the STEM mode). Emission spectra were collected for 120 seconds at $75 \mathrm{kv}$. Average counts for each element from 4 analyses per group were calculated.

\subsection{Blood Analysis}

These studies were conducted on large fish only. Fish were stunned with a blow on the head; immediately after this, 1-3 ml of blood was collected by cardiac puncture using a 22 gauge needle attached to a $3 \mathrm{ml}$ syringe containing traces of heparin. The blood was immediately analyzed for a number of parameters as outlined below:

1. Blood oxygen using a Clark-type electrode

2. Carbon dioxide using a Severinghaus-stow-type electrode

3. $\mathrm{pH}$ by flow-through glass capillary and reference assembly

4. Total carbon dioxide, bicarbonate and base excess were calculated by the machine based on the Henderson-Hasselbach equation. 
The above parameters were measured using a Corning Model 78 $\mathrm{pH} / \mathrm{blood}$ gas analyzer. All measurements and calculations of the analyzer were corrected according to body temperature of the fish $\left(12^{\circ} \mathrm{C}\right)$ and hemoglobin values $(9.0 \mathrm{gm} / \mathrm{dl})$ using the Kelman and Nunn formula.

The sampling and analytical techniques can be expected to have altered the above parameters. Capture and blood sampling probably decreased blood $\mathrm{pH}$ and $\mathrm{PO}_{2}$ and increased $\mathrm{CO}_{2}$ via metabolic acid production and branchial failure upon removal of the fish from the water. Warming of blood from $12^{\circ} \mathrm{C}$ to $37^{\circ} \mathrm{C}$ for measurement purposes will alter $\mathrm{pH}, \mathrm{O}_{2}$ and $\mathrm{CO}_{2}$ values. Using human-derived correction factors to back-adjust the resultant measurements to $12^{\circ} \mathrm{C}$ may have led to some error. This is especially true for $\mathrm{PO}_{2}$ values because fish blood exhibits both Bohr and Root shifts, whereas human blood exhibits only Bohr shifts. $\mathrm{PCO}_{2}$ values generated using the above technique must also be treated with caution because the expected values for fish blood (1-4 torr) are well outside the calibration range of the analyzer (about 35-70 torr).

5. Hematocrit

6. The remaining blood was then centrifuged and the plasma was harvested for biochemical analysis. A KDA biochemistry instrument and packaged reagents (American Monitor Corporation, Mississauga, Ontario) were used for determination of plasma biochemistry values. 
a. Plasma sodium $\left(\mathrm{Na}^{+}\right)$and potassium $\left(\mathrm{K}^{+}\right)$by flame photometry.

b. Chloride $\left(\mathrm{Cl}^{-}\right)$by modified Schoenfeld and Lowellen method.

c. Glucose is determined using an initial glucose oxidase reaction.

d. Total protein utilizing biuret reagent.

e. Aspartate aminotransferase (AST) and alanine aminotransferase (ALT) activity correlated with the disappearance of NADH as double enzymatic reactions.

\subsection{Statistical Analysis}

A. Small Fish

Data on the above project have been analyzed to study the effects of Hercofloc (H), Effluent (E), Concentration (C) and their interaction on gill and skin lesions.

The effects of $H, E$ and $C$ were tested by using the following statistical model:

$$
Y_{i j k 1}=\mu+H_{i}+E_{j}+H E_{i j}+H C_{i k}+e_{i j k 1}
$$

where: $Y_{i j k 1}=1$-th observation ( $f$ ish on $k$-th concentrations, $j$-th effluent, and $i$-th Hercofloc,

$\mu \quad=$ general mean,

$H_{i} \quad=$ Effect of $i$-th Hercofloc $i=1,2 \ldots 7$,

$E_{j} \quad=$ Effect of $j$-th effluent $j=1,2$ 


$$
\begin{array}{ll}
C_{k} & =\text { Effect of } k \text {-th concentration, } k=1,2 \ldots 6, \\
H E, H C, E C & =\text { respective interaction terms, } \\
\text { eijkl } & =\text { random error associated with each observation. }
\end{array}
$$

Subsequent to the analysis of variance, main effect (H, E, C) means were compared by using the least significant difference (LSD) test. Means not different from others at $\alpha=.05$ were joined by a line. Breakdown analysis of variance was also performed.

B. Large Fish

Data were analyzed to assess the effects of Hercoflocs on the induction of lesions and on biochemical and blood gas parameters. Data were grouped and analyzed into 4 sub-groups: acute toxicity, subacute $96 \mathrm{~h}$ exposure, subacute $192 \mathrm{~h}$ exposure, and acute + subacute $96 \mathrm{~h}$ exposure.

The effects of Hercofloc compared to a control treatment (Hercofloc $=0$ ) on each parameter were tested by using a one-way analysis of variance model. The model used was:

$$
Y_{i j}=\mu+\alpha_{i}+e_{i j},
$$

Where: $\begin{array}{ll}Y_{i j} & =j \text {-th observation (fish on the } i \text {-th Hercofloc) } \\ \mu & =\text { general mean, } \\ \alpha_{i} & =\text { effect of } i \text {-th Hercofloc, } i=1-7, \\ e_{i j} & =\text { random error associated with each observation. }\end{array}$


Hercofloc means were also compared by using the least significant difference (LSD) method. Means not different at $\alpha=0.5$ were connected by an underline.

\section{RESULTS}

\subsection{Acute Toxicity in Small Fish}

1. The $96 \mathrm{~h} L \mathrm{C}_{50}$ of nonionic $H-1110$, and anionic $H-1121$ and $H-1142$ were $>150 \mathrm{mg} / \mathrm{L}$, whether they were mixed with municipal water or mine effluent (Table 6).

2. The $96 \mathrm{~h} \mathrm{LC} 50$ of anionic $\mathrm{H}-1123$ was $>150 \mathrm{mg} / \mathrm{L}$ when combined with municipal water. When mixed with mine effluent, H-1123 caused $100 \%$ mortality at concentrations 10 and $50 \mathrm{mg} / \mathrm{L}$ but caused no mortality at 100 and $150 \mathrm{mg} / \mathrm{L}$ (Table 6).

3. H-1132 and H-1137 (both cationic) were not acutely toxic when combined with effluent; however, their 96 LC 50 were 50-100 and $10-50 \mathrm{mg} / \mathrm{L}$ respectively when mixed with treated municipal water. Table 6 gives the $L_{5} C_{0}$ for the different Hercoflocs.

4. Effluent alone (control) produced a higher incidence of gill lesions (79.3\%) than when it is combined with the flocculants (53.8\%) (Appendix II).

5. Hercofloc flocculants combined with treated municipal water induced a higher incidence of gill and skin lesions than treated municipal water alone (control) (Appendix II). 
Table 6. Acute toxicity ( $96 \mathrm{~h} \quad \mathrm{LC}_{50} ; \mathrm{mg} / \mathrm{L}$ ) of different Hercofloc flocculants to small rainbow trout measuring $2.5-6 \mathrm{~cm}$ in length.

\begin{tabular}{|c|c|}
\hline Hercofloc & $96 \mathrm{~h} \mathrm{LC} \mathrm{C}_{50}$ \\
\hline $\begin{array}{l}1110 \\
1121 \\
1123 \\
1132 \\
1137 \\
1142\end{array}$ & $\begin{array}{r}>150 \\
>150 \\
>150 \\
50-100 \\
10-50 \\
>150\end{array}$ \\
\hline Hercofloc & $96 \mathrm{hLC}_{50}$ \\
\hline $\begin{array}{l}1110 \\
1121 \\
1123 \\
1132 \\
1137 \\
1142\end{array}$ & $\begin{aligned} & >150 \\
& >150 \\
10, & 50,100,150 * \\
& >150 \\
& >150 \\
& >150\end{aligned}$ \\
\hline
\end{tabular}

${ }^{*} 100 \%$ mortality at 10 and $50 \mathrm{mg} / \mathrm{L} ; 0 \%$ mortality at 100 and $150 \mathrm{mg} / \mathrm{L}$.

6. Effluents alone (control) produced no skin lesions at all; however, their combination with the Hercoflocs produced an incidence of $9.8 \%$ skin lesions (Appendix II).

7. In small fish, the statistical analysis did not show significant correlation between concentration (1-150 ppm) and the incidence and severity of skin and gill lesions. This variation in number and severity of lesions indicates dependence on the final concentration of the flocculants in water or effluent (Appendix III). 


\subsection{Subacute Toxicity in Large Fish}

In the treated municipal water the $L_{50}{ }^{\prime}$ 's of anionic $H-1121$, $\mathrm{H}-1123$ and $\mathrm{H}-1142$ were $>150 \mathrm{mg} / \mathrm{L}$ and thus the flocculants were not considered acutely toxic. Hercofloc 1132 (cationic) had an LC $_{50}$ of 1-50 $\mathrm{mg} / \mathrm{L}$ whereas the corresponding value for $\mathrm{H}-1137$ (cationic) was $0.5-1.0 \mathrm{mg} / \mathrm{L}$. Table 7 shows these results.

Table 7. Subacute toxicity ( $96 \mathrm{~h} L C_{50}, \mathrm{mg} / \mathrm{L}$ ) of different Hercofloc flocculants to large rainbow trout, using treated municipal water as diluent.

\begin{tabular}{cc}
\hline Hercofloc & $96 \mathrm{~h} \mathrm{LC} \mathrm{LC}_{50}$ \\
\hline 1110 & $>150$ \\
1121 & $>150$ \\
1123 & $>150$ \\
1132 & $1-50$ \\
1137 & $0.5-1$ \\
1142 & $>150$ \\
\hline
\end{tabular}

\subsection{Histopathology}

In both small and large fish, the skin and gills were the main target organs of the flocculants. Depending on their severity, lesions in these tissues were categorized into mild, moderate, marked and severe. A representative histopathological description of each of these lesions in the gills and skin is given below.

1. Mild Gill Lesions: These lesions are characterized by focal shortening, hyper-cellularity and/or fusion of secondary lamellae. Histologic architecture of the primary and secondary 
lamellae is not affected. Epithelial cells of the affected lamellae are mostly cuboidal and hyper-cellularity of the subepithelial spaces is due to epithelial cell proliferation and mononuclear inflammatory cell infiltration.

2. Moderate Gill Lesions: Moderate gill lesions are characterized by diffuse shortening, fusion and hyper-cellularity of the affected secondary lamellae and might extend to up to $50 \%$ of the examined lamellae.

3. Marked Gill Lesions: These lesions might involve up to $75 \%$ of the examined lamellae. Marked subacute and chronic lesions are characterized by shortening, fusion and hyper-cellularity of the secondary lamellae. In acute lesions, necrosis and sloughing of the lamellar epithelium with or without subepithelial edema are usually seen. Histologic architecture of the affected lamellae is altered.

4. Severe Gill Lesions: Severe gill lesions involved more than $75 \%$ of the examined lamellae. These lesions are acute and necrosis of the lamellar epithelium with disruption of the secondary lamellae are consistent features. Edema at the subepithelial spaces may be seen.

Lesions in the skin of the examined fish were either mild or moderate.

1. Mild Skin Lesions: These lesions are characterized by focal degeneration and necrosis of the superficial epidermal epithelium. Sloughing of the necrotic cells may be seen. 
2. Moderate Skin Lesions: These lesions are focal and characterized by necrosis and degeneration of the superficial $2 / 3$ epidermal epithelium. Vacuolation and sloughing of the epidermal epithelial cells may be seen. A few mononuclear inflammatory cells may be seen migrating to the surface of the affected areas.

Tables 8,9 and 10 summarize histopathological findings in small and large fish.

\subsection{Electron Microscopy}

1.A. H-1110 (nonionic) $96 \mathrm{~h}$ post-exposure $150 \mathrm{mg} / \mathrm{L}$ : The pavement epithelium was composed of cuboidal cells or slightly flattened epithelial cells. Numerous cuboidal and less mature cells were seen near the junction between the secondary and primary lamellae. In some lamellae, the pavement epithelial cells were separated from the underlying capillaries by undifferentiated cells, macrophages and polymorphonuclear leukocytes. This leukocytic infiltration was remarkable at the primary-secondary lamellar junction. Most of the cuboidal cells had well developed endoplasmic reticulum with moderate numbers of darkly stained lysosomes.

Two types of chloride cells were seen. The first type had a moderate number of mitochondria with well developed rough endoplasmic reticulum. A large number of phagolysosomes were noticed in the upper third of the cell. Phagolysosomes were round, granular and of moderate electron density. The content of the lysosomes suggested 


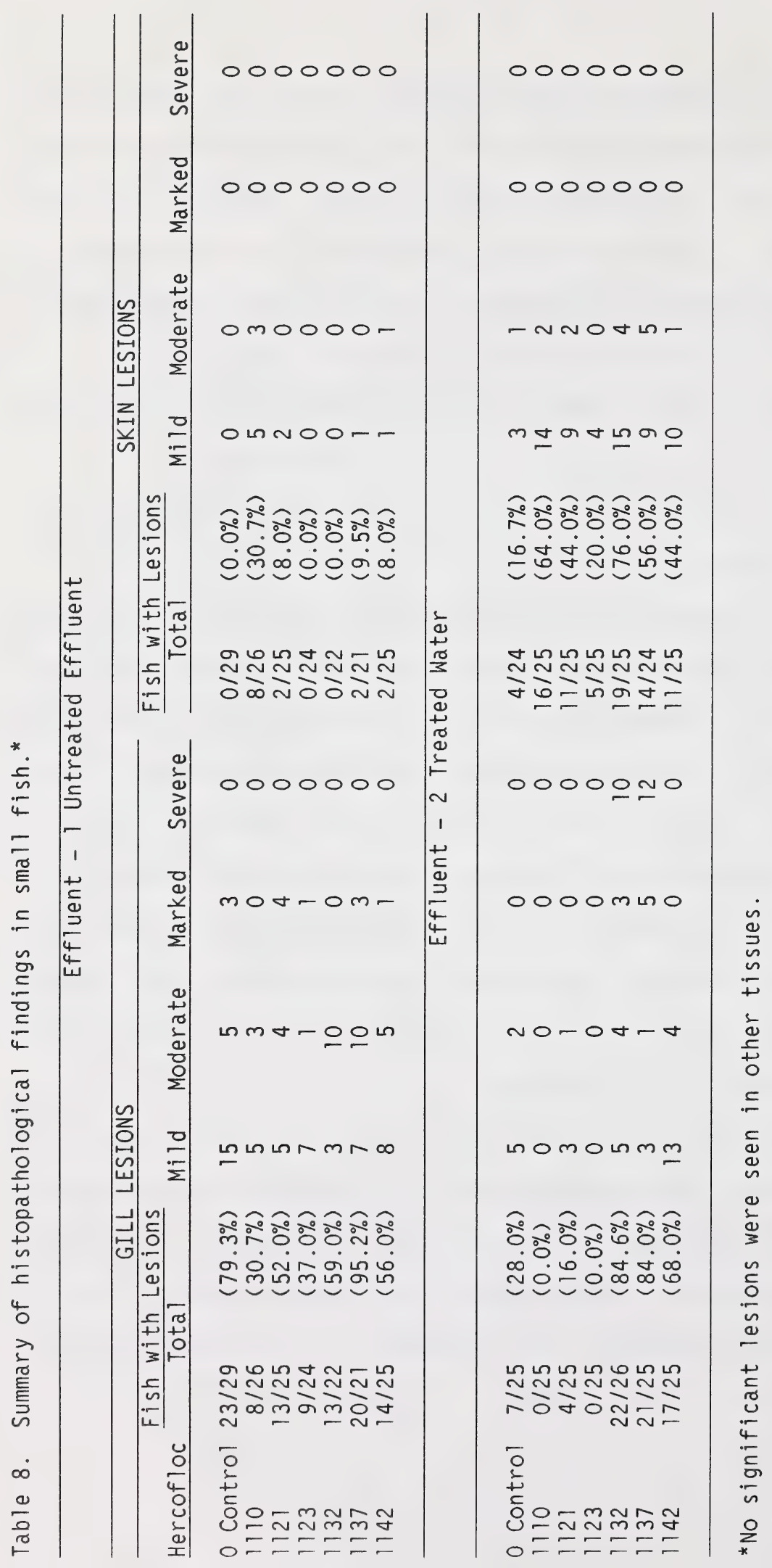




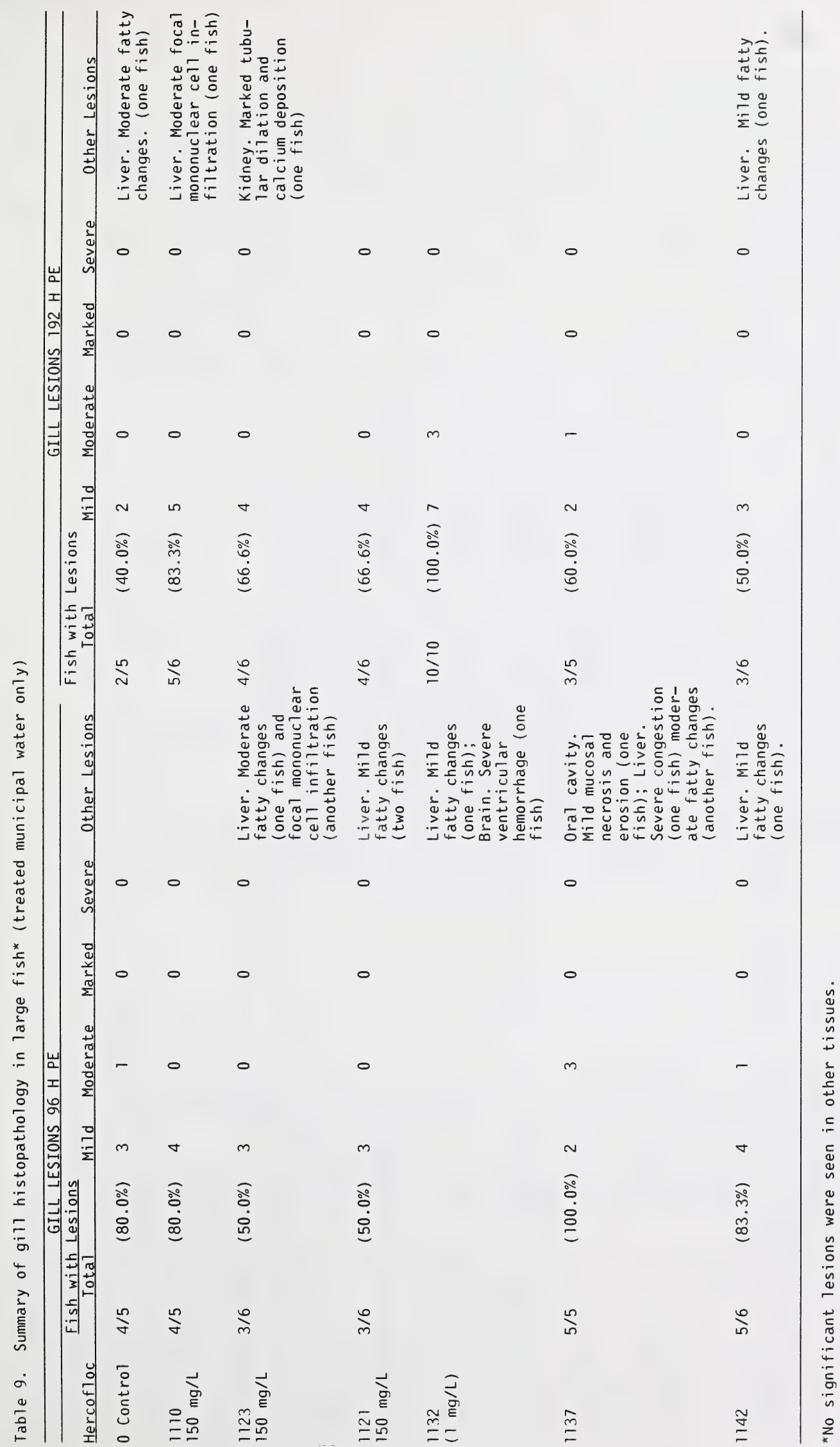




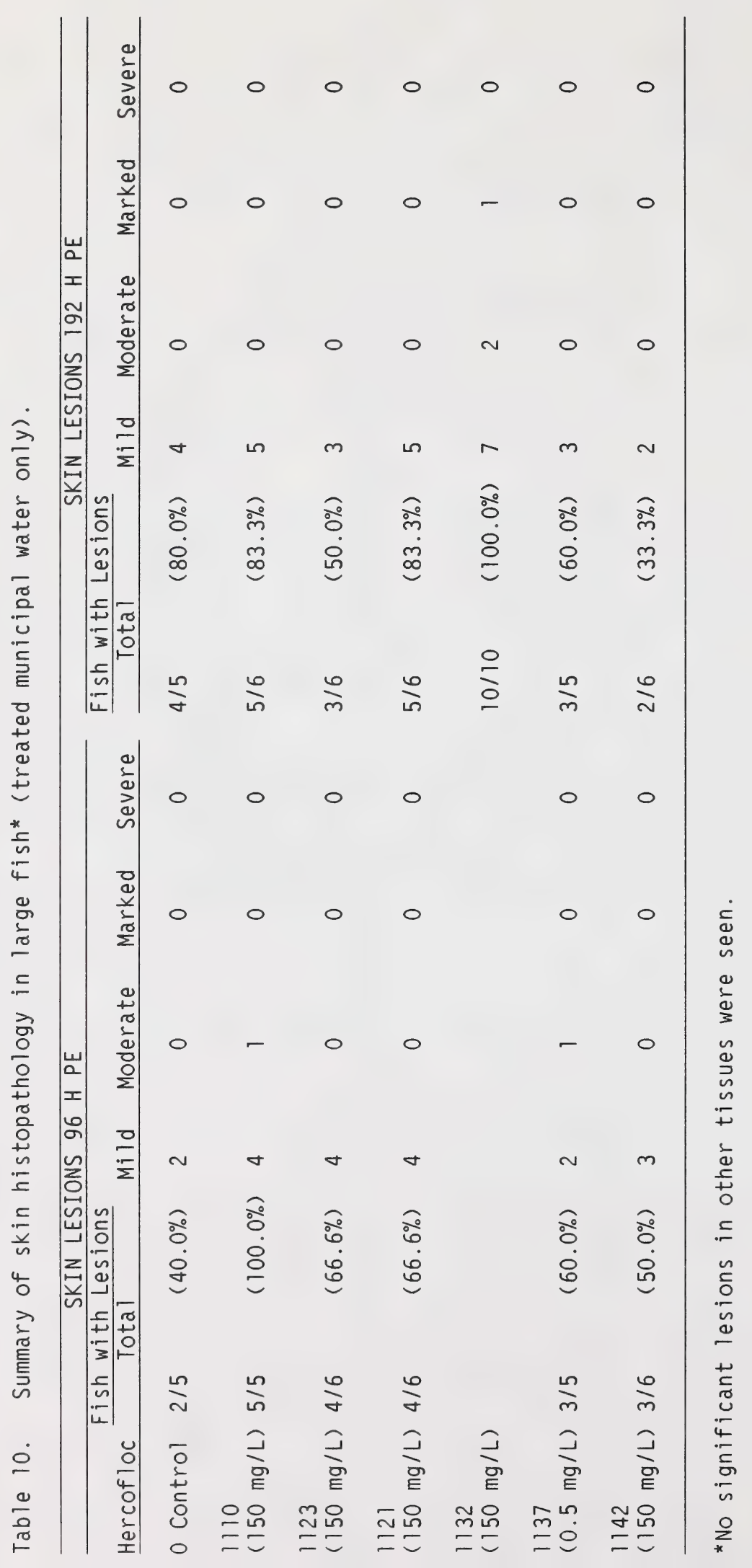


that they originated from the endoplasmic reticulum and cytoplasmic vesicles. Many of these lysosomes resembled "multivesicular bodies". The second type of chloride cells had large numbers of mitochondria with a well developed smooth endoplasmic reticulum. The phagolysosomes were large but few in number. They were of heterogenous electron density and their content had resemblance to mitochondria and endoplasmic reticulum.

2.A. H-1121 (anionic) $96 \mathrm{~h}$ post-exposure $150 \mathrm{mg} / \mathrm{L}$ : The pavement epithelium of the secondary lamellae was composed of cuboidal or thick flat epithelial cells. They were separated from the underlying capillaries by one or two layers of undifferentiated cells. Many of these cells had large phagolysosomes filled with degenerated cellular organelles which appeared as whorls or myelin-like figures.

The chloride cells had very well developed endoplasmic reticulum and many of them were filled with darkly stained lysosomes or phagolysosomes of different sizes.

2.B. H-1121 (anionic) $192 \mathrm{~h}$ post-exposure $150 \mathrm{mg} / \mathrm{L}$ : The morphological changes in the secondary lamellae were similar to the previous time period except for larger darkly stained phagolysosomes present between the pavement epithelial cells and the underlying blood vessels. Other phagolysosomes were seen also and they contained endoplasmic reticulum and mitochondria at different stages of degeneration. 
3. H-1142 96 (anionic) $\mathrm{h}$ post-exposure $150 \mathrm{mg} / \mathrm{L}$ : No significant changes were seen except for a few surface epithelial cells containing large phagolysosomes.

\subsection{X-ray Microanalysis}

EM elemental analysis of the flocculants provided evidence for the presence of chlorine and sulfur. Occasionally, sodium was also detected. These results were confirmed with x-ray fluorescence techniques in the Air Analysis and Research Station, Chemistry Wing.

This method of analysis is able to detect elements with molecular weight above 20. Therefore, the material appears predominantly organic in nature.

Since elemental characterization of the flocculant did not show the presence of heavy elements, evaluation of the fish gill tissues exposed to various flocculants, for elemental analysis at the ultrastructural level was not attempted. Ultrastructural studies were carried out by transmission electron microscopy.

\subsection{Blood Analysis}

Blood gas analysis: No significant alterations were noted in the blood $\mathrm{pH}$ and $\mathrm{pO}_{2}$ and $\mathrm{pCO}_{2}$ in all the principal fish tested at 96 and 192 hours post-exposure to the six flocculants at the non-lethal concentrations. 


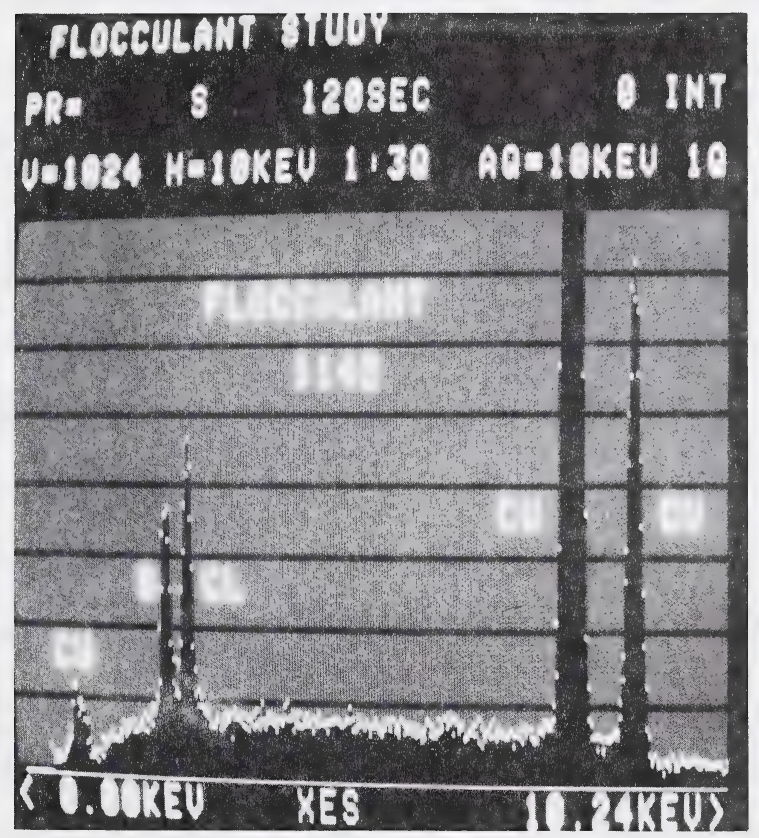

Fig. 5. Energy dispersive $x$-ray analysis of freeze-dried flocculant no. 1142 showing detectable level of chlorine and sulfur. The three Cu peaks represent grid copper. 
Glucose: No significant changes were noted in the concentration of blood glucose in the principal and control fish at 96 hours post-exposure (Table 11). At 192 hours, the high mean value of glucose from five fish exposed to $\mathrm{H}-1110$ was biologically and statistically significant when compared to the control.

Electrolytes $\left(\mathrm{Na}^{+}\right.$and $\left.\mathrm{Cl}^{-}\right)$: The changes in the concentration of blood potassium were biologically not significant in the principal fish at 96 and 192 hours post-exposure. Statistically significant higher potassium values were noted in fish at 192 hours post-exposure to $H-1110$ and $H-1123$ (Significant at $\alpha=.05$ ).

Statistically significant higher concentrations of sodium and chloride were noted in fish exposed to $\mathrm{H}-1137$ at 96 hours, $\mathrm{H}-1123$ and H-1131 at 192 hours post-exposure. Minor elevations in the levels of $\mathrm{Na}^{+}$and $\mathrm{CL}^{-}$in the blood have no biological significance in the fish. However, a decrease in their levels is biologically significant and this was seen in one control fish at 96 hours in treated municipal water. The fish blood had $113.00 \mathrm{mM} / \mathrm{L}$ and $90 \mathrm{mM} / \mathrm{L}$ sodium and chloride respectively. These changes were associated with high glucose concentration (33.9 mol/L) in the blood. No significant histopathological alterations were seen in the examined tissues and the clinico-pathological changes in the electrolytes and glucose were attributed to terminal stress. These low values in one fish markedly lowered the mean and markedly increased the standard deviation of the 4 control fish used at 96 hours. If we compare the principal fish to 
historical control values (Table 12), we find that the electrolyte values in the principal fish are similar to the control.

Total protein values and liver enzyme activity (SGOT and SGPT) were within the normal limits in the principal fish at 96 and 192 hours.

Table 11 summarizes these results.

\subsection{Hercofloc 1137 and 1132 (cationic) Detailed}

These two flocculants were the most toxic in comparison to the rest. A $100 \%$ mortality in large fish occurred within 6 hours after exposure to 1 and $10 \mathrm{mg} / \mathrm{L}$ of $\mathrm{H}-1137$ and $50 \mathrm{mg} / \mathrm{L}$ of $\mathrm{H}-1132$.

Histopathology The gills were the target organ of the flocculants. Lesions in the gills consisted of diffuse necrosis of the squamous epithelial cell covering the secondary lamellae. These cells were completely separated from the underlying cells. This separation and sloughing was associated with discontinuity of the epithelial lining at the tips of the secondary lamellae (Fig. 6). Cells between the blood vessels and the epithelium were swollen and had no identifiable cell membrane. Their nuclei were pyknotic and fragmented. Most of the blood vessels were markedly contracted and were lacking red blood cells in their lumen.

These changes were associated with severe edema that resulted in separation of the secondary lamellae (subepithelial spaces) (Fig. 7). Edema fluid was of low density and it stained faintly with eosin. 
号主

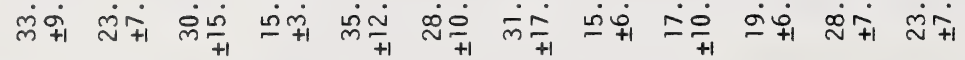

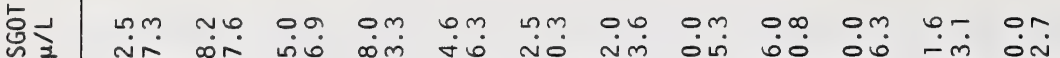
ஸิن

ப一

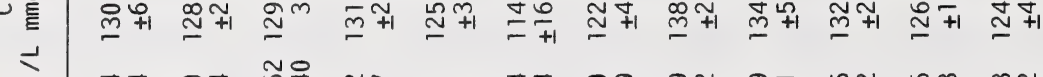

$+\frac{\circ}{\square}$ +

L

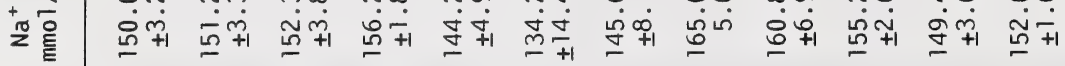

岁方

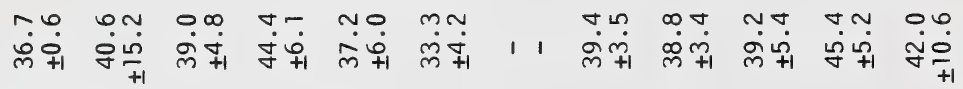

00 n- on $\infty$ n $\infty$ n n бं

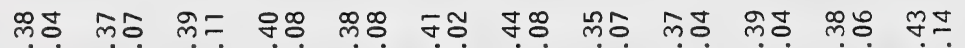
녹

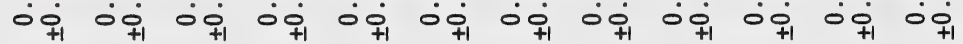

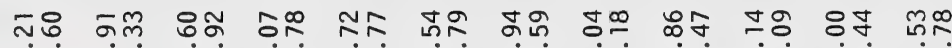

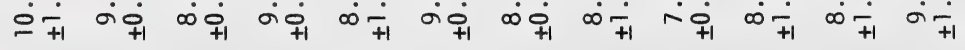

$\tilde{n}=$

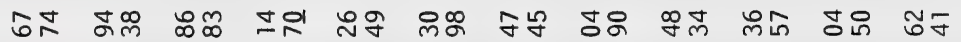

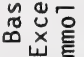

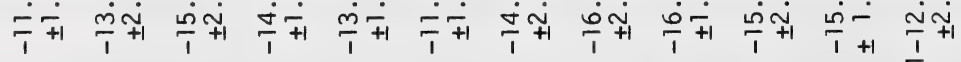

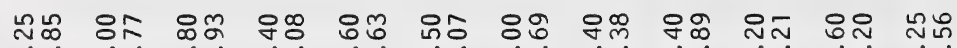

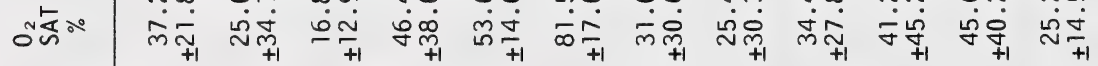

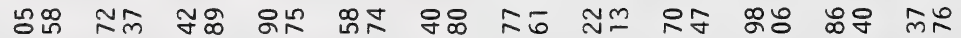
宅产

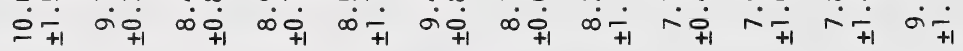

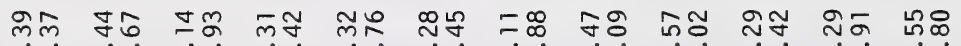

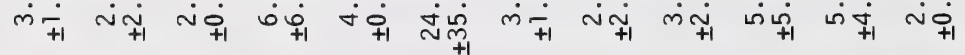

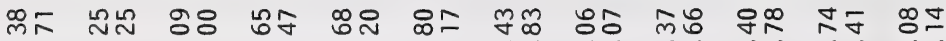
율ํㅗㄹ

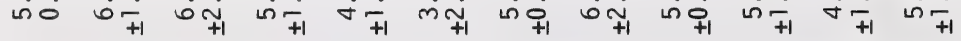

동

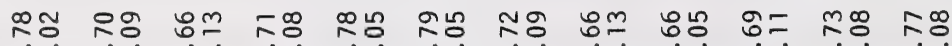

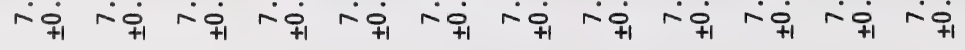
to $\frac{5}{5}$ n n in

น

$\forall$

\begin{tabular}{|c|c|c|c|c|}
\hline חم & مـ & مـ & مـ & n \\
\hline $\begin{array}{l}\frac{\Sigma}{\sigma} \\
\frac{1}{1} \\
\varrho \\
\bar{I} \\
\frac{1}{1}\end{array}$ & 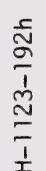 & $\frac{\frac{\mathfrak{N}}{\frac{1}{n}}}{\frac{1}{\frac{1}{n}}}$ & $\begin{array}{l}\text { Nั } \\
\frac{1}{1} \\
\frac{m}{1} \\
\frac{1}{1}\end{array}$ & 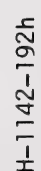 \\
\hline
\end{tabular}




\begin{tabular}{|c|c|c|c|c|}
\hline 记 & 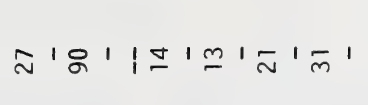 & $\begin{array}{llll}1 & 1 & 1 & 1 \\
\mathrm{~m}\end{array}$ & 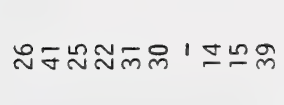 & 요 \\
\hline 兮さ & 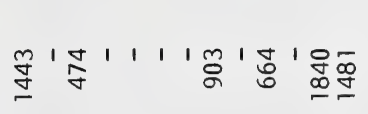 & $\begin{array}{llll}1 & 1 & 1 & 1 \\
\end{array}$ & 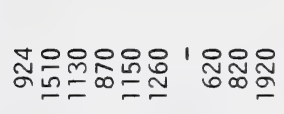 & 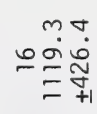 \\
\hline : & ్ㅠㅛㅗㅁ ' ' & $1111 \cong$ & 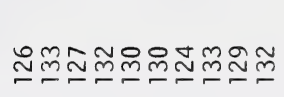 & $\begin{aligned} & \stackrel{\infty}{\infty} \\
\approx & \stackrel{\sim}{\simeq}+1\end{aligned}$ \\
\hline 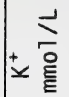 & 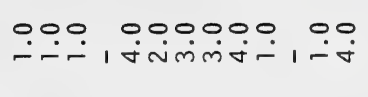 & $\begin{array}{llllll}1 & 1 & 1 & 1 & 0\end{array}$ & 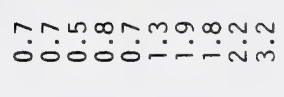 & $\approx \stackrel{\circ}{\sim} \frac{+}{+1}$ \\
\hline$+\frac{1}{2}$ & 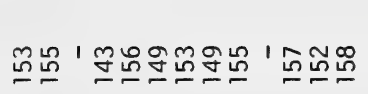 & 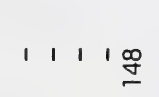 & 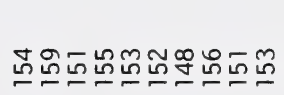 & $\approx \tilde{\sim} \tilde{n}+1$ \\
\hline 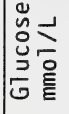 & $\begin{array}{llllllllllll}1 & 1 & 1 & 1 & 1 & 1 & 1 & 1 & 1 & 1 & 1 & 1\end{array}$ & $\begin{array}{lllll}1 & 1 & 1 & 1 & 1\end{array}$ & 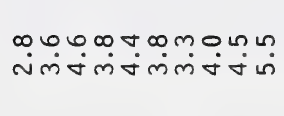 & 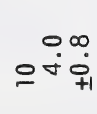 \\
\hline 운 & $\begin{array}{llllllllllll}1 & 1 & 1 & 1 & 1 & 1 & 1 & 1 & 1 & 1 & 1 & 1\end{array}$ & $1111 \%$ & 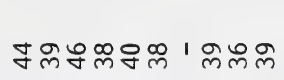 & 윰ำ \\
\hline 높 & $\begin{array}{lllll}\stackrel{\infty}{q}+ & \stackrel{n}{q} & \stackrel{n}{q} & \bar{\tau} & \stackrel{q}{0} \\
\dot{0} & \stackrel{0}{0} & \dot{0} & \dot{0} & \stackrel{0}{0}\end{array}$ & 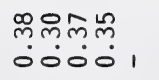 & 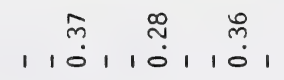 & mọ \\
\hline No & 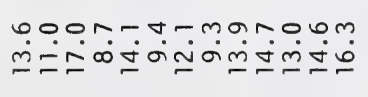 & 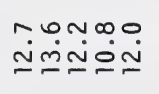 & mor & $\Sigma \stackrel{\nabla}{\sim} \underset{+}{\sim}$ \\
\hline 送 & 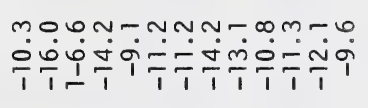 & 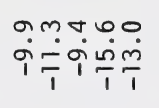 & 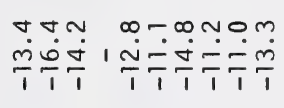 & $\approx \underset{1}{\sim} \underset{+}{\sim}$ \\
\hline 告 & 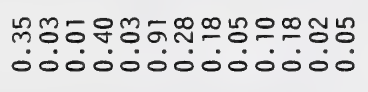 & 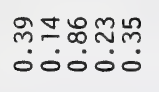 & 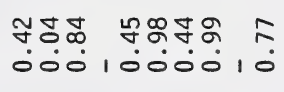 & 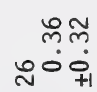 \\
\hline 宅高 & 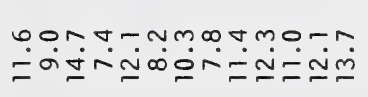 & 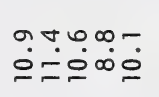 & ஸ் & $\hat{\sim}^{\infty} \stackrel{\infty}{\sigma}$ \\
\hline - & 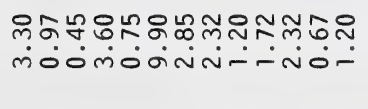 & 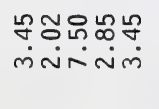 & 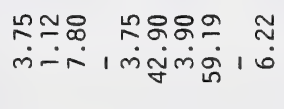 & 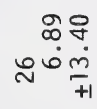 \\
\hline 导올 & 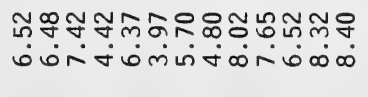 & 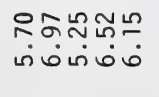 & 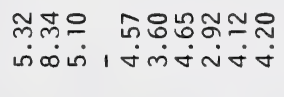 & $\hat{n}^{\infty}$ \\
\hline 좀 & 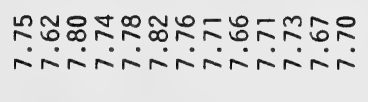 & 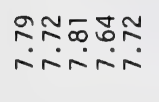 & 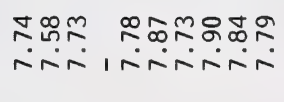 & añó \\
\hline 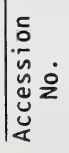 & 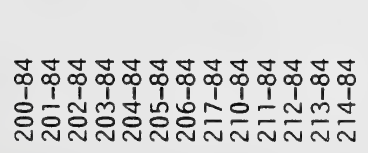 & 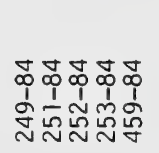 & 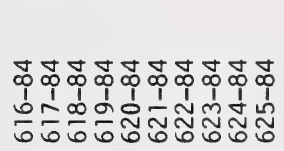 & 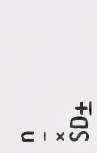 \\
\hline
\end{tabular}


Most of the chloride cells had sloughed out. They have pyknotic nuclei with irregular cytoplasmic membrane.

No severe gill lesions (epithelial necrosis and edema) were seen in the fish exposed to $0.5 \mathrm{mg} / \mathrm{L}$ of $\mathrm{H}-1137$ and $1 \mathrm{mg} / \mathrm{L}$ of $\mathrm{H}-1132$ in treated municipal water. All ten exposed fish survived $96 \mathrm{~h}$ exposure. Fish exposed to $\mathrm{H}-1137$ at $0.5 \mathrm{mg} / \mathrm{L}$ had mild to moderate gill lesions which were characterized by hyper-cellularity, shortening and fusion of secondary lamellae. Table 13 summarizes histopathological findings in the skin and gills in fish exposed to these two Hercoflocs.

\section{Electron Microscopy}

1.A. H-1132 $50 \mathrm{mg} / \mathrm{L}$ four hours post-exposure: The gill lesions were characterized by sloughing and disruption of the fuzzy coat (glycocalyx) over the squamous epithelial cells. The sloughed filaments coagulated and formed dark round or elongated bodies. The squamous cells were necrotic, the endoplasmic reticulum was distended and the mitochondria were moderately swollen. The nuclei were shrunken and condensed and the chromatin was marginated on or adjacent to the nuclear envelope (Fig. 8). No significant lesion was seen in the undifferentiated cells between the squamous epithelium and the blood vessels. Many necrotic chloride cells were seen and their mitochondria were severely affected. They were markedly distended with disrupted cristae (Fig. 9). There were no significant ultrastructural changes in the mucus secreting cells and in the blood vessels. 
1.B. H-1132 (cationic) $1 \mathrm{mg} / \mathrm{L} 8$ days post-exposure: The secondary lamellae were thickened due to leukocytic infiltrations and undifferentiated epithelial cell proliferation between the surface epithelium and the capillaries. Many of the leukocytes and some of the undifferentiated cells contained large homogeneous and heterogeneous phagolysosomes of variable electron density.

1.C. $\mathrm{H}-1132$ (cationic) $1 \mathrm{mg} 9$ days post-exposure: Similar changes were seen at this time period and many of the phagolysosomes contained nuclear and cytoplasmic debris (Fig. 10). The chloride cells had a mixture of well developed smooth and rough endoplasmic reticulum at the upper third of the cell. Large numbers of short type endoplasmic reticulum with polyribosomes spread throughout the cell were seen also. Electron dense round or elongated lysosomes were seen in large numbers in the upper third of the cell (Fig. 11). A few polymorphonuclear cells and a moderate number of lymphocytes were seen in the subepithelial spaces.

1.D. H-1132 (cationic) $1 \mathrm{mg} / \mathrm{L} 10$ days post-exposure: Changes were similar to those seen in the previous time period.

2.A. $\mathrm{H}-1137$ (cationic) $10 \mathrm{mg} / \mathrm{L}$ and $1 \mathrm{mg} / \mathrm{L} 11 / 2$ to 6 hours post-exposure: Necrosis and sloughing of the surface epithelium was observed. The necrotic cells had a markedly electron dense (dark) vacuolated cytoplasm. This vacuolation was probably due to 
destruction of the outer cell plasma membrane. The mitochondria were slightly swollen. The nuclei had condensed, clumped and marginated chromatin (Fig. 12).

The sloughing involved the whole surface epithelium of the secondary lamellae without separation of the necrotic epithelial cells from each other. In a few instances, there was a discontinuity of the surface epithelium resulting in loss of body fluids and dissociation of the underlying cells to the outside (Fig. 13 and 14). Many necrotic mucus secreting cells were seen with no discharge of their mucin granules.

An influx of large amounts of fluid into the interstitial spaces caused partial or complete separation of the subepithelial cells from each other and from the covering epithelial cells and underlying basement membrane of blood vessels (Fig. 12). Many of these separated cells had distended cytoplasm and a few of them had ruptured plasma membranes (Fig. 14). The cytoplasmic distension involved white blood cells as well (Fig. 15).

Many of the blood vessels in the secondary lamellae were empty and the pillar cells were contracted. In rare instances, changes in the red blood cells were noticed and characterized by destruction of the nuclear envelope and seepage of nuclear material into the cytoplasm (Fig. 16).

Many necrotic chloride cells were seen. Their upper plasma membrane was destroyed and resulted in escaped mitochondria and other organelles to the outside. The mitochondria were markedly swollen 
with separated cristae. The nuclei had clumped and marginated chromatin (Fig. 17.)

2.B. H-1137 (cationic) $0.5 \mathrm{mg} / \mathrm{L}, 96$ hours post-exposure: No significant ultrastructural changes were seen in the surface epithelium. Surface epithelial cells were separated from the underlying blood vessels by a layer of 3 to 4 cells in thickness. These subepithelial cells were composed of undifferentiated cells, macrophages and lymphocytes. A few macrophages had large phagolysosomes in their cytoplasm (Fig. 18). In a few instances, macrophages adhered to the surface epithelial cells, and the plasma membrane of the macrophage appeared fenestrated. No cellular organelles were seen crossing between the two cells (Fig. 19 and 20).

No significant ultrastructural changes were seen in the chloride cells.

2.C. H-1137 (cationic) $0.5 \mathrm{mg} / \mathrm{L}, 192$ hours post-exposure: Gill changes were similar to those seen in the previous time period except for larger numbers of macrophage laden with large phagolysosomes. They were composed of remnants of mitochondria, myelin-like figures and multiple electron dense round particles (Fig. 21). A few chloride cells had mild swelling of mitochondria with separation of their cristae and cytoplasmic rarefaction. Large numbers of electron dense round lysosomes were seen at the upper third of the chloride cells with well developed smooth endoplasmic reticulum. 


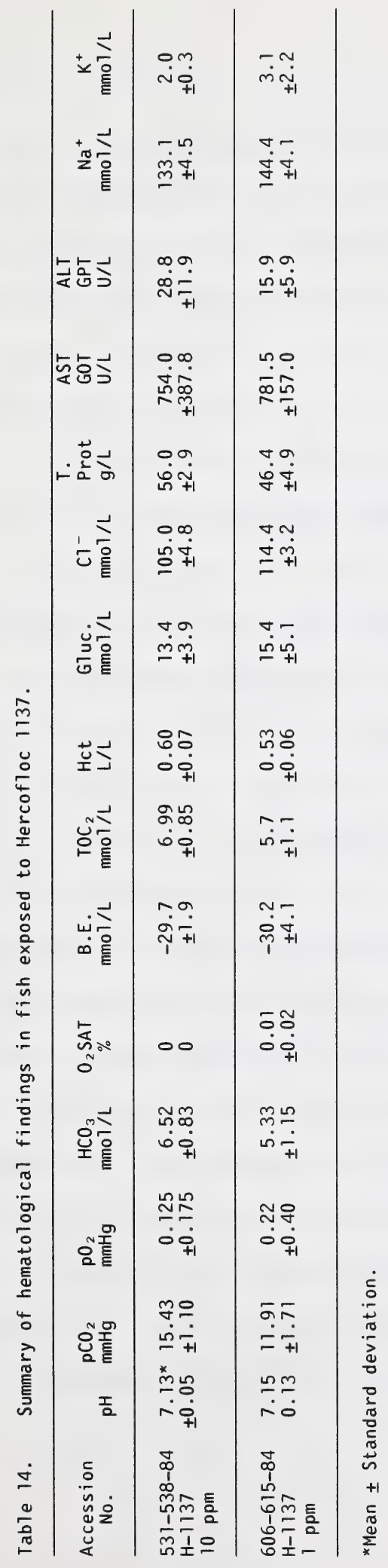


Blood Analysis $\mathrm{H}-1137$ (cationic)

The clinicopathological alterations in fish exposed to 1 and 10 ppm H-1137 were characterized by marked decrease in blood pH, partial pressure of oxygen $\left(\mathrm{pO}_{2}\right)$, bicarbonate $\left(\mathrm{HCO}_{3}\right)$, total $\mathrm{CO}_{2}$ $\left(\mathrm{TCO}_{2}\right)$, oxygen saturation $\left(\mathrm{O}_{2} \mathrm{SAT}\right)$, sodium $\left(\mathrm{Na}^{+}\right)$and chloride $\left(\mathrm{Cl}^{-}\right)$. Hematocrit (HCT), total protein (T. Prot.), glucose, potassium $\left(\mathrm{K}^{+}\right)$and base excess (B.E.) (became more negative) were increased. These changes were more pronounced in fish exposed to 10 ppm H-1137. No significant alterations in the activity of liver enzymes were noted.

The clinicopathological findings in fish exposed to $0.5 \mathrm{ppm} \mathrm{H}-1137$ were described previously. Table 14 summarizes these findings.

\section{DISCUSSION AND CONCLUSIONS}

Hercofloc 1110 (nonionic) and Hercoflocs 1121 and 1142 (both anionic) were not considered toxic at the concentrations tested whether mixed with mine effluent or treated municipal water. H-1123 was not toxic when combined with municipal water. $\mathrm{H}-1123$ caused $100 \%$ mortality when mixed with mine effluent at concentrations of 10 and 50 $\mathrm{mg} / \mathrm{L}$. However, it caused no mortality when combined with effluent at concentrations of 100 and $150 \mathrm{mg} / \mathrm{L}$. This is due to the fact that, at the two lower concentrations, the flocculant did not induce precipitation of the suspended material. It therefore remained free 
in the solution, resulting in direct exposure to fish. At the two high concentrations (100 and $150 \mathrm{mg} / \mathrm{L})$, the suspended solids were precipitated, thereby removing the flocculant from the water column and reducing exposure of fish to its toxic effect.

Subacute tests indicated that large rainbow trout are either equally sensitive or more sensitive to Hercofloc flocculants than small rainbow trout.

Among all the flocculants tested, $\mathrm{H}-1132$ and $\mathrm{H}-1137$ (both (ationic) were considered the most toxic in both studies when mixed with treated municipal water. Histopathological study confirmed this observation. These two flocculants caused the highest incidence and the most severe lesions in the gills and skin than other flocculants.

Effluent by itself produces a higher incidence of gill lesions than when it is combined with Hercofloc (Appendix II). This means that Hercoflocs reduce the toxic effect of the effluent on the gills. The mechanism of this reduction is due to coalescing activity of the flocculants with the suspended colloids in the effluent. This results in settling of the flocculant and suspended solids and removes them from the water column.

The acute necrotic lesions seen in the gill epithelium are not specific to the cationic flocculants; previous studies reported similar types of gill lesions in fish exposed to toxic levels of detergent, phenol, zinc and formaldehyde (Abel and Skidmore, 1975; Mitrovic et al., 1968; Brown et al., 1968; Skidmore and Tove11, 1972; Smith and Piper, 1972). The electron microscopic findings of this 
study showed that the plasma membrane and mitochondria were the targets of flocculant toxicity. These early changes were clearly seen in chloride cells. The plasma membrane is the primary target since the flocculants have to penetrate and damage the barriers of the cell's plasma membrane and intervening cytoplasm before they reach the mitochondrial membranes.

The cell coat (fuzzy coat or glycocalyx) that covers the plasma membrane of the gill epithelium is composed of negatively charged acidic mucopolysaccharides. The negative charges serve to repel adjacent cells and prevent adhesions (Robbins and Cotran, 1979). The cationic flocculants carry positive charges on the surface of the molecule. The negative and positive charges on the epithelial cells and flocculant surfaces respectively would result in attachment of flocculant to the epithelial surface and exposure of plasma membrane to the damaging effects of the flocculants. On the other hand, the negative charges surrounding the anionic flocculants might be partly responsible for non-lethal effects of these flocculants on the negatively charged gill epithelial cells.

The respiratory and chloride cells of the gills play an important role in osmoregulation and acid base balance in addition to other vital functions of respiratory gas exchange (Randall, 1970). In the freshwater fish, the renal $\mathrm{Na}^{+}$and $\mathrm{Cl}^{-}$losses and the passive loss of the electrolytes along the concentration gradient across the boundaries is compensated for by an active uptake of ions by the gills (Girard and Payan, 1980). Thus, damage to the plasma membrane of the 
gill epithelium would result in the failure of gas exchange and osmoregulation. These were clearly demonstrated by the significant chemical and morphological alterations found in the blood and gills respectively of fishes exposed to lethal concentrations of the flocculants. These changes were characterized by low $\mathrm{Na}^{+}, \mathrm{Cl}^{-}$, $\mathrm{pO}_{2}$ and high $\mathrm{pCO}_{2}$ in the blood and marked interstitial and intracellular edema in the gills. As mentioned earlier, the method of blood extraction may have affected $\mathrm{pO}_{2}$ and $\mathrm{pCO}_{2}$.

Fish exposed to non-lethal concentrations of the flocculants showed changes in chloride cells, undifferentiated epithelial cells and macrophages. The chloride cells had large numbers of dark vesicles and lysosomes in the proximal third of the cell. Recent studies have shown that freshwater trout gills are permeable to organic substances of high molecular weight (mannitol, dextran, inulin) and noted an accumulation of these substances in the chloride cells (Isaia et al., 1978; Girard and Payan, 1980). These studies lend support to the suggestion that flocculant molecules leaked into the chloride cell cytoplasm and resulted in the formation of lysosomes and vesicles.

Large phagolysosomes were seen in macrophages and undifferentiated cells of the gills. The content varied from completely digested material to well differentiated cytoplasmic organelles (endoplasmic reticulum and mitochondria). The origin of these organelles is not clear. A previous study (Daoust et al., 1984) has shown earlier stages of the same process present in gills of rainbow trout exposed 
to inorganic mercury and copper. It has a resemblance to the apoptosis process seen in mammals. This process in various mammalian cells can be inhibited or initiated by a variety of environmental stimuli, both physiological and pathological (Kerr et al., 1972; Don et al., 1977). It is indicative of lethal injury to the cell where the parenchymal cell condenses and breaks into a number of membrane-bound fragments known as apoptosic bodies. These bodies then are phagocytized and digested by other cells where they are rapidly degraded by lysosomal enzymes derived from the ingesting cells. In summary, these changes are indicative of increased turnover at the cellular and subcellular levels in the fish gills.

To our knowledge, there has been no previous report describing fenestration in plasma membrane of macrophages present in gill secondary lamellae. It can be suggested that fenestration would enhance the transport of $\mathrm{O}_{2}, \mathrm{CO}_{2}, \mathrm{Na}^{+}$and $\mathrm{Cl}^{-}$between blood vessels and the surface epithelium. This suggestion is supported by evidence of normal blood $\mathrm{pO}_{2}, \mathrm{pCO}_{2}$ and electrolytes in fish that have multi layers of cells separating the respiratory epithelial cells from the underlying blood vessels. Previous studies have suggested that such hyper-cellularity in the secondary lamellae would impair gas exchange. This study disagrees with the above suggestion and further studies are needed on the effect of cellular proliferation in the secondary lamellae on the respiratory gas exchange and osmoregulation in fish gills. 


\section{REFERENCES}

Abel, P.D. and J.F. Skidmore. 1975. Toxic effects of an anionic detergent on the gills of rainbow trout. Water Research 9:769-765. Alberta Environmental Centre. 1984. Effects on fish of effluents and flocculants from the Coal Valley Mine. Alberta Environmental Centre AECV84-R4. p. 81 .

Brown, V.M., C.C. Mitrovic, and G.T.C. Stark. 1968. Effects of chronic exposure to zinc on toxicity of a mixture of detergent and zinc. Water Research 2:255-263.

Daoust, P.Y., G. Wobeser and J.D. Newstead. 1984. Acute pathological effects of inorganic mercury and copper in gills of rainbow trout. Vet. Pathol. 21:93-101.

Don, M.M., G. Ablett, C.J. Bishop, P.G. Bundesen, K.J. Donald, J. Searle and J.F.R. Kerr. 1977. Death of cells by apoptosis following attachment of specifically allergized lymphocytes in vitro. Austr. J. Exp. Biol. Med. Sci. 55:407-417.

Girard, J.P. and P. Payan. 1980. Ion exchange through respiratory and chloride cells in freshwater and seawater-adapted teleosteans. Am. J. Physiol. 238:R260-R268.

Isaia, J., J. Maetz, and J.P. Haywood. 1978. Effects of epinephrine on branchial non-electrolyte permeability in rainbow trout. J. Exp. Biol. 74:227-237. 
Kerr, J.F.R., A.H. Wyllie, and A.R. Currie. 1972. Apoptosis: a basic biological phenomenon with wide-ranging implications in tissue kinetics. Brit. J. Cancer. 26:239-257.

McGuinness, E. 1982. Procedures manual: Aquatic Bioassay Service Projects. Alberta Environmental Centre Manuscript Report. AECV-82MI .

Mitrovic, V.V., V.M. Brown, D.G. Shurben, and M.H. Berryman. 1968.

Some pathological effects of subacute and acute poisoning of rainbow trout by phenol in hard water. Water Research. 2:249-254. Randa11, D.J. 1970. The circulatory system. In: Fish Physiology, ed. W.S. Hoar and D.J. Randal1, Volume IV, pp. 133-168. Academic Press, New York.

Robbins, S.L. and R.S. Cotran. 1979. The normal and adapted cell. In: Pathologic Basis of Disease. pp. 1-21. W.B. Saunders Co., Philadelphia.

Skidmore, J.F. and P.W.A. Tovel1. 1972. Toxic effects of zinc sulphate on the gills of rainbow trout. Water Research. $6: 217-230$.

Smith, C.E. and R.G. Piper. 1972. Pathological effects in formalintreated rainbow trout (Salmo gairdneri). J. Fish. Res. Bd. Can. 29:328-329. 
(48)

APPENDIX I.

MICROGRAPHS 


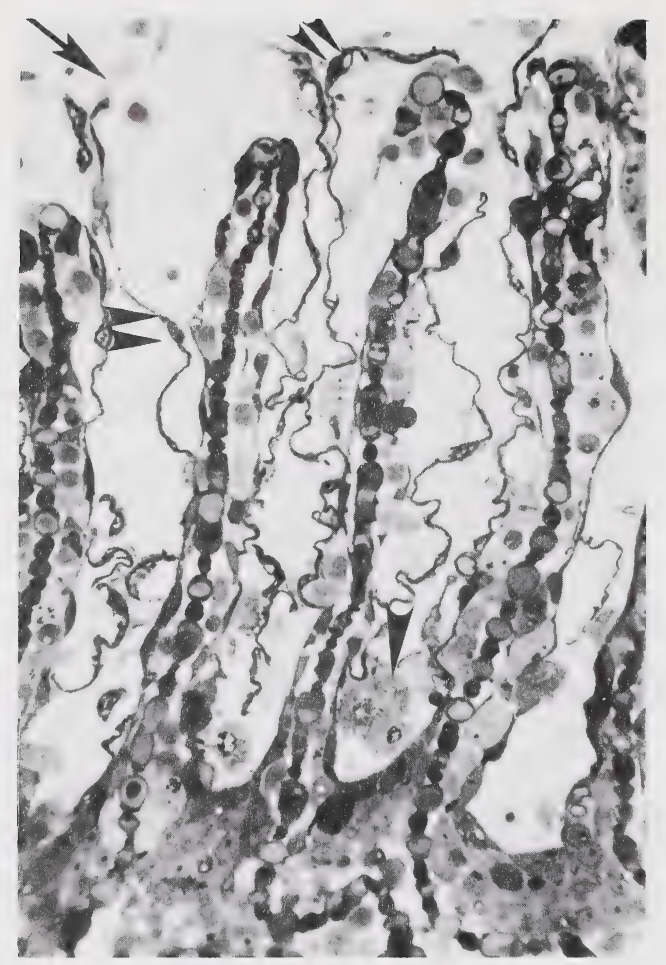

Figure 6. Photomicrograph of gill secondary lamellae from a fish exposed to $10 \mathrm{ppm} \mathrm{H}-1137$. Note the separation of the necrotic pavement epithelial cells (arrow heads), broken epithelium at tip of the lamellae (arrow), necrosis and sloughing of chloride cells (arrow head) and contraction of the blood vessels. Methylene blue azur II, $x 462$. 


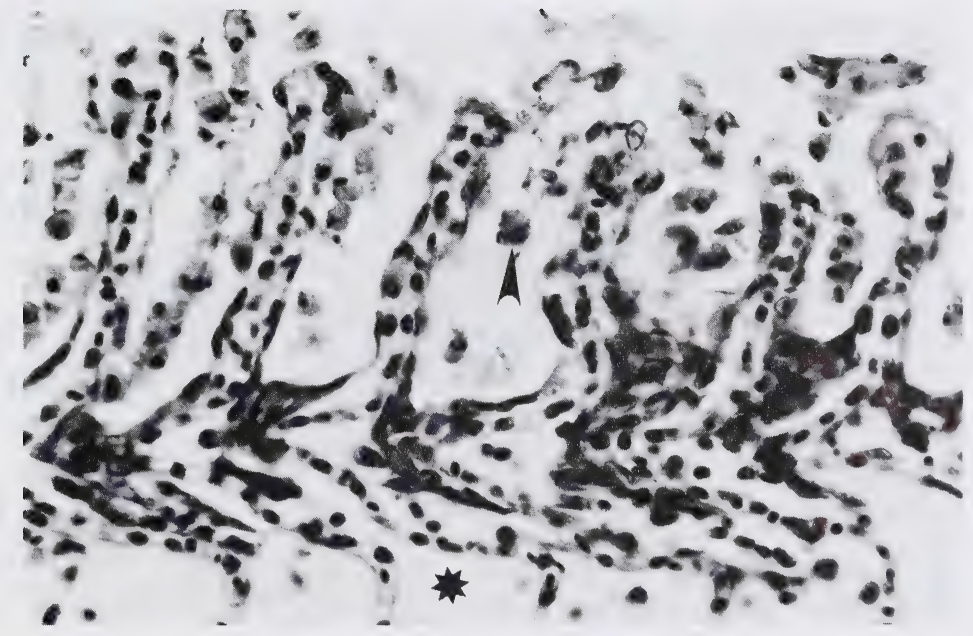

Figure 7. Photomicrograph of gill secondary lamellae from a fish exposed to $50 \mathrm{ppm} \mathrm{H}-1132$. Note the separation and sloughing of the pavement epithelium and chloride cells (arrow head) with marked edema of the subepithelial spaces $\left({ }^{*}\right)$. H \& $E, x 462$. 


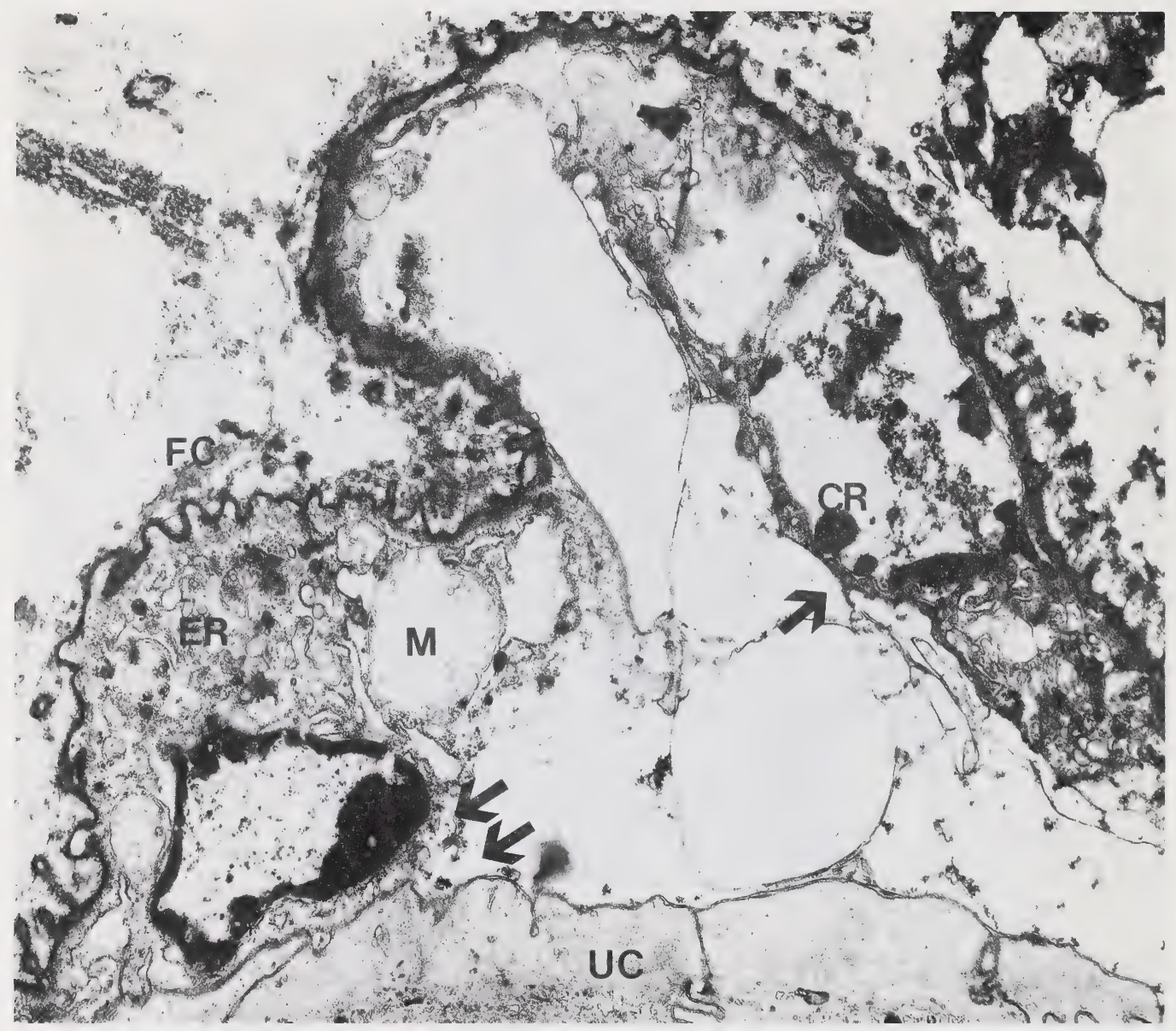

Figure 8. Electron micrograph of a gill secondary lamellae from a fish exposed to $50 \mathrm{ppm} \mathrm{H}-1132$. Note the separation of 2 necrotic pavement epithelial cells (arrows) from the underlying undifferentiated cells (UC). The necrotic cells have distended endoplasmic reticulum (ER), swollen mitochondria (M), condensed and marginated nuclear chromatin (CR) and separated fuzzy coat (FC). Uranyl acetate and lead citrate, $x 1000$. 


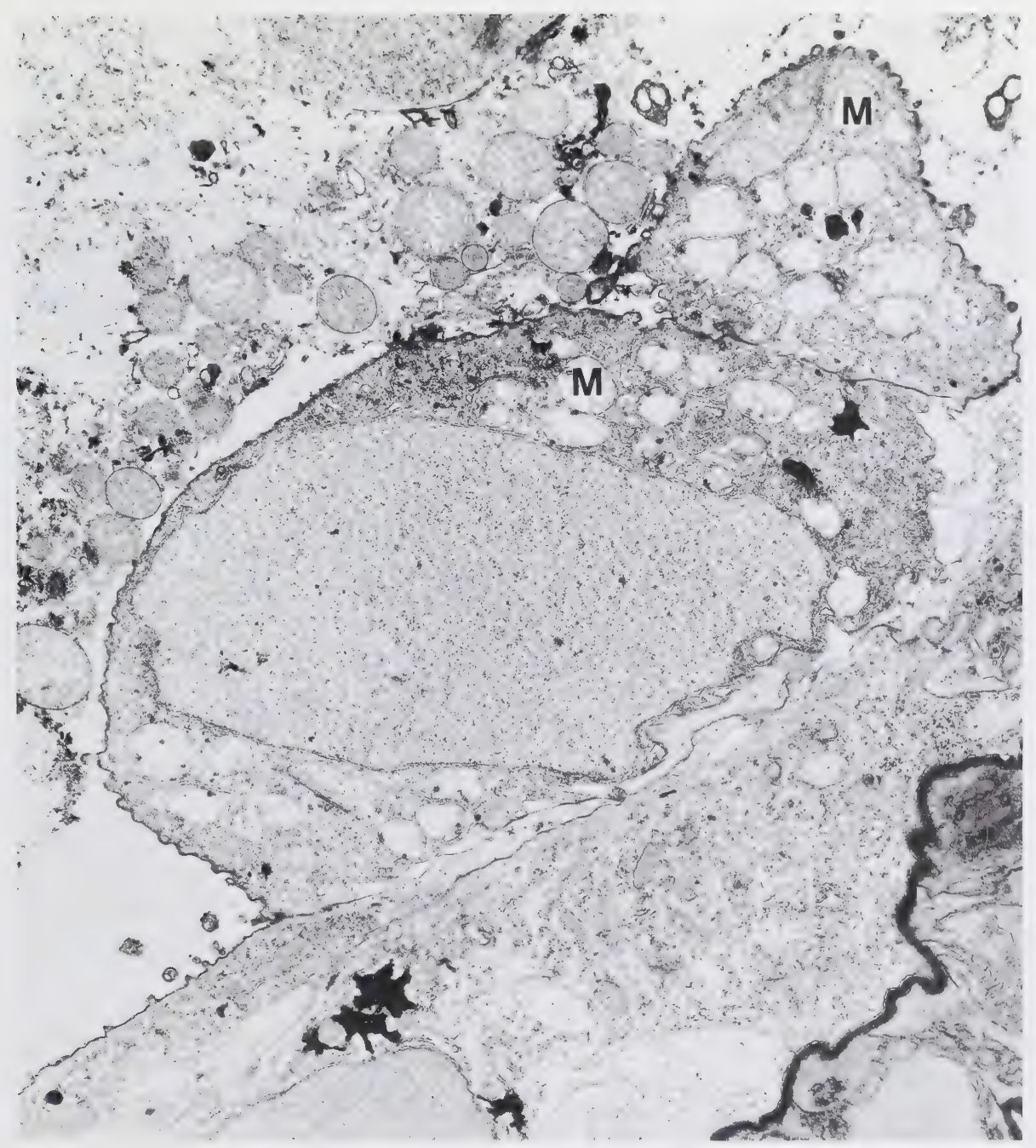

Figure 9. Electron micrograph of a partially sloughed necrotic chloride cell from a fish gill exposed to $50 \mathrm{ppm}$ $\mathrm{H}-1132$. Note the marked swelling of the mitochondria (M) with separation of their cristae. Many extracellular mitochondria from another necrotic chloride cell are seen in the upper left corner admixed with cellular debris. Uranyl acetate and lead citrate, $\times 6000$. 


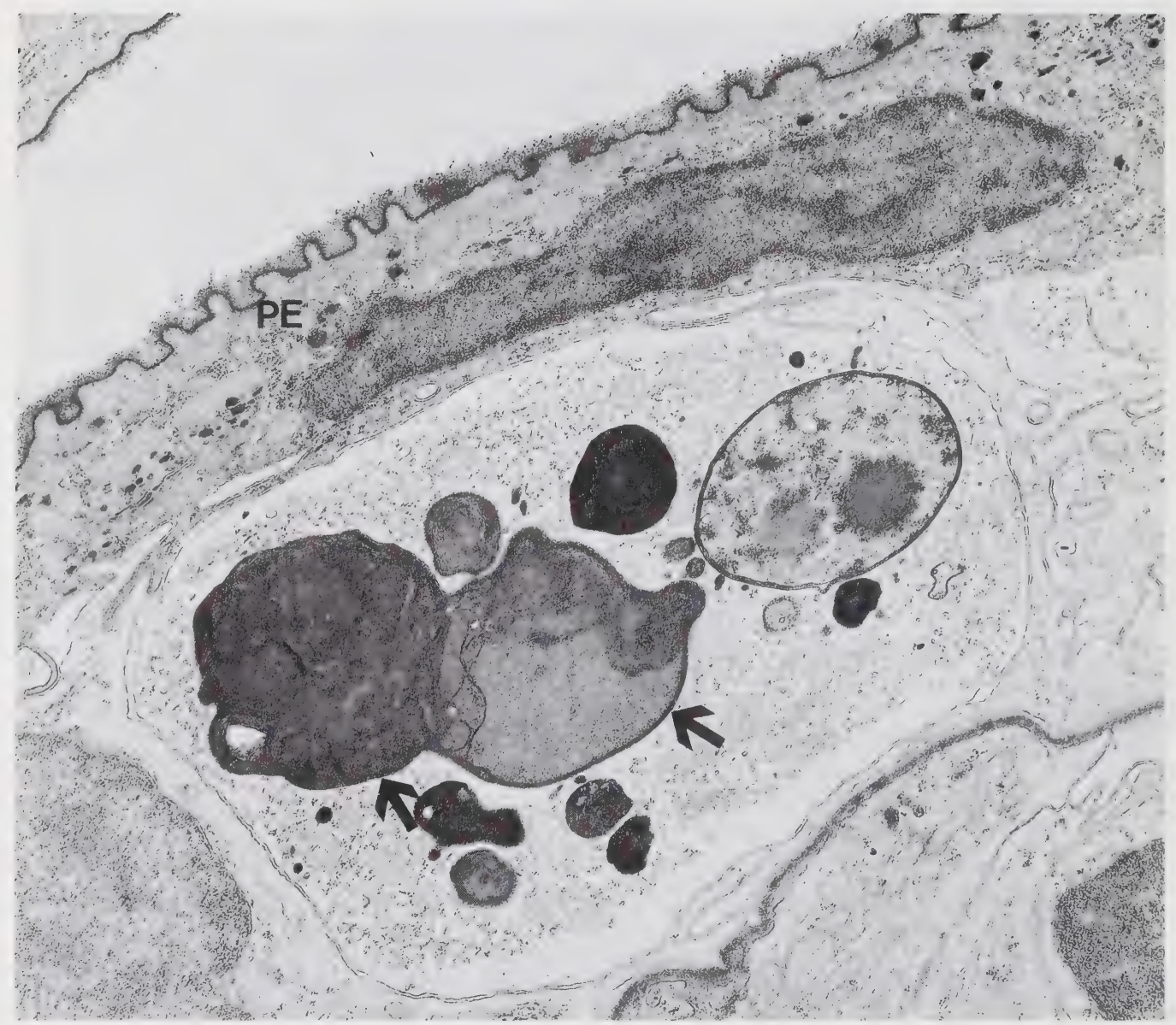

Figure 10. Electron micrograph of a gill secondary lamellae from a fish 8 days after exposure to $1 \mathrm{ppm} \mathrm{H}-1132$. Note the large electron dense phagolysosomes (arrows) in the cytoplasm of a macrophage. The pavement epithelial cell is normal (PE). Uranyl acetate and lead citrate, $x$ 12000 . 


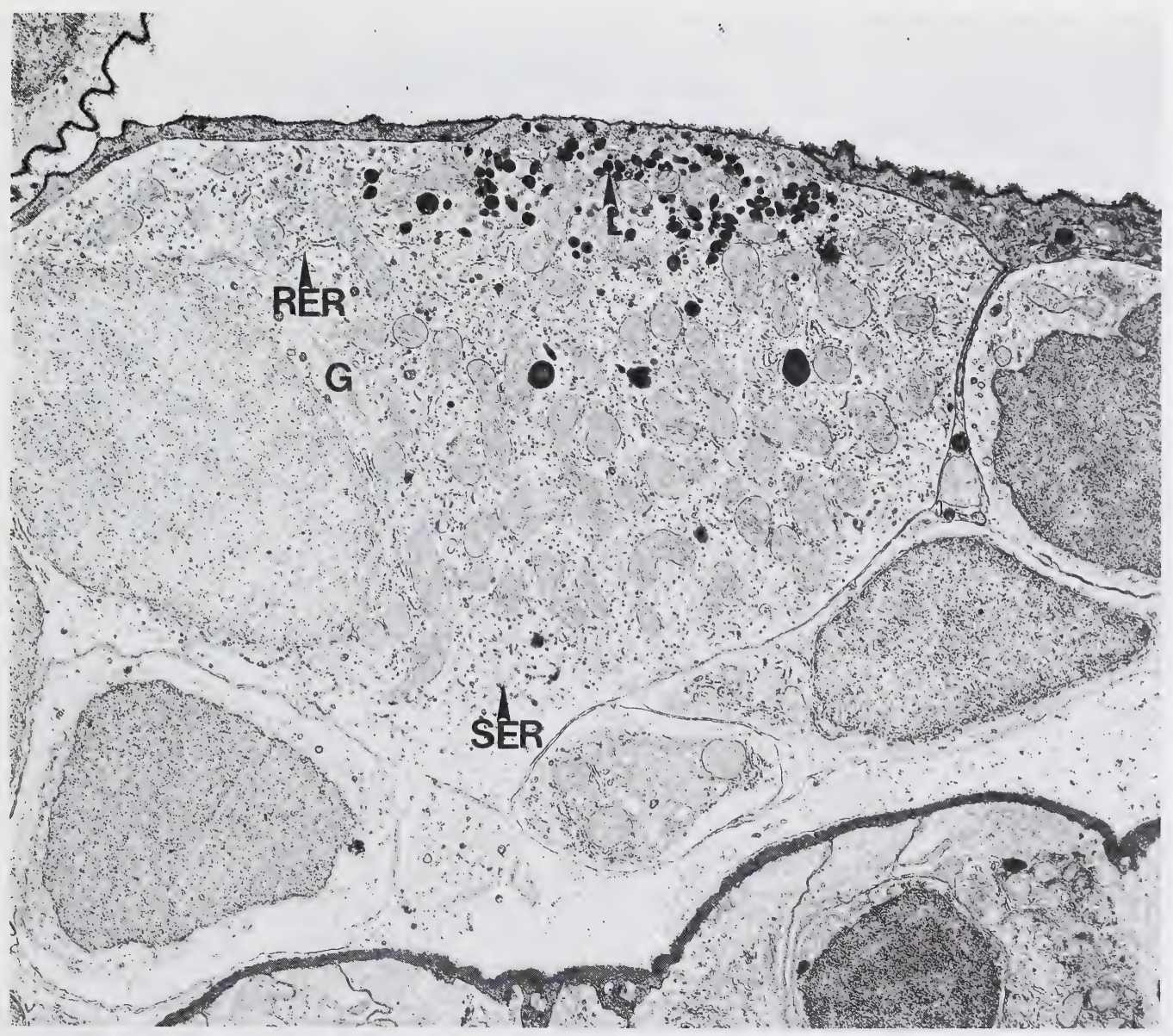

Figure 11. Electron micrograph of a chloride cell from a fish 9 days after exposure to $1 \mathrm{ppm} \mathrm{H-1132.} \mathrm{Note} \mathrm{the} \mathrm{well}$ developed smooth endoplasmic reticulum (SER), rough endoplasmic reticulum (RER), Golgi apparatus (G) and large number of lysosomes. Uranyl acetate and lead citrate, x 80000 . 


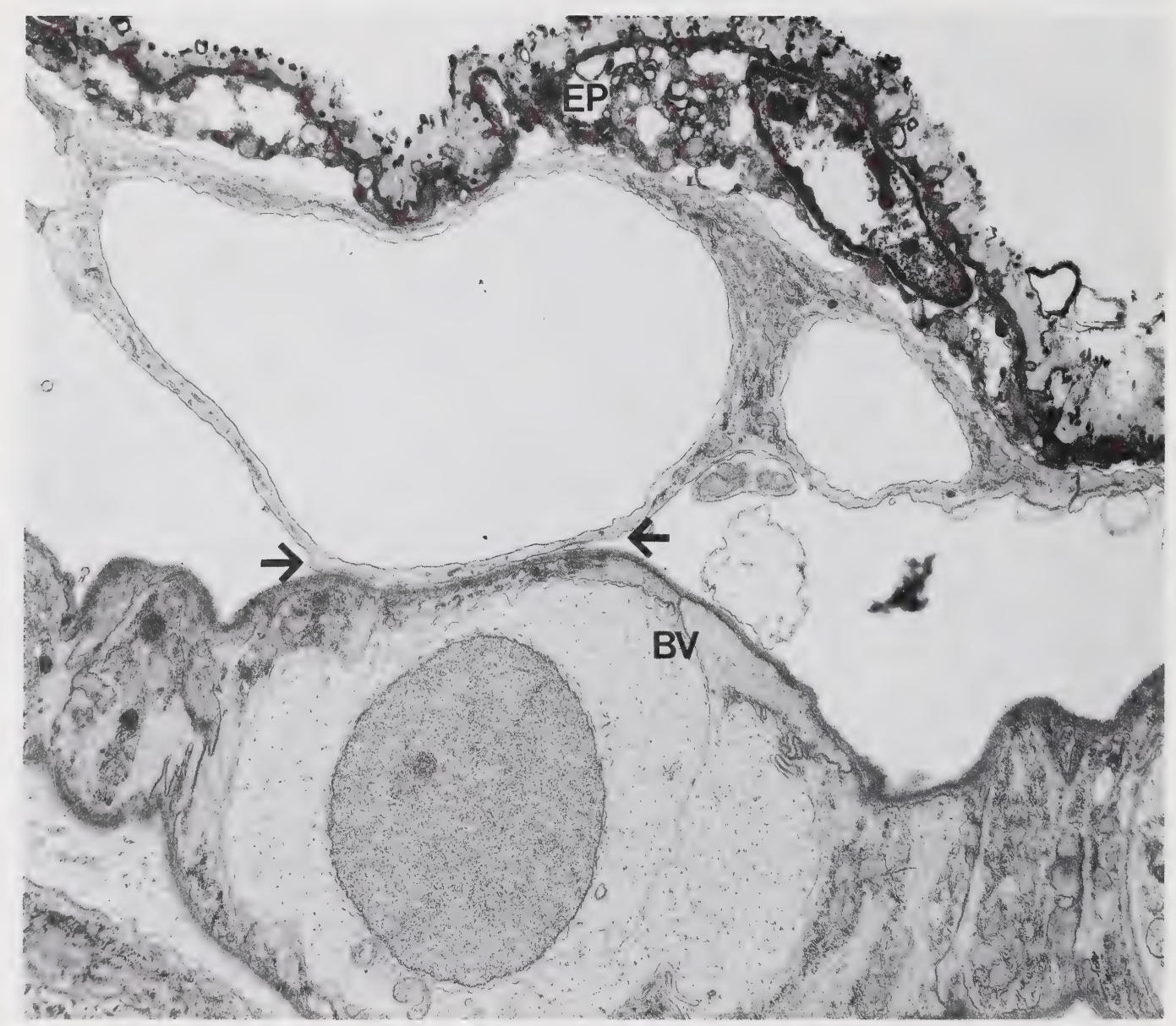

Figure 12. Electron micrograph of a gill secondary lamella from fish exposed to $10 \mathrm{ppm} \mathrm{H}-1137$. Note the diffuse necrosis of the pavement epithelial cells (EP) and separation (arrows) of the undifferentiated epithelial cells from the underlying blood vessels (BV). Uranyl acetate and lead citrate, $x 8000$. 


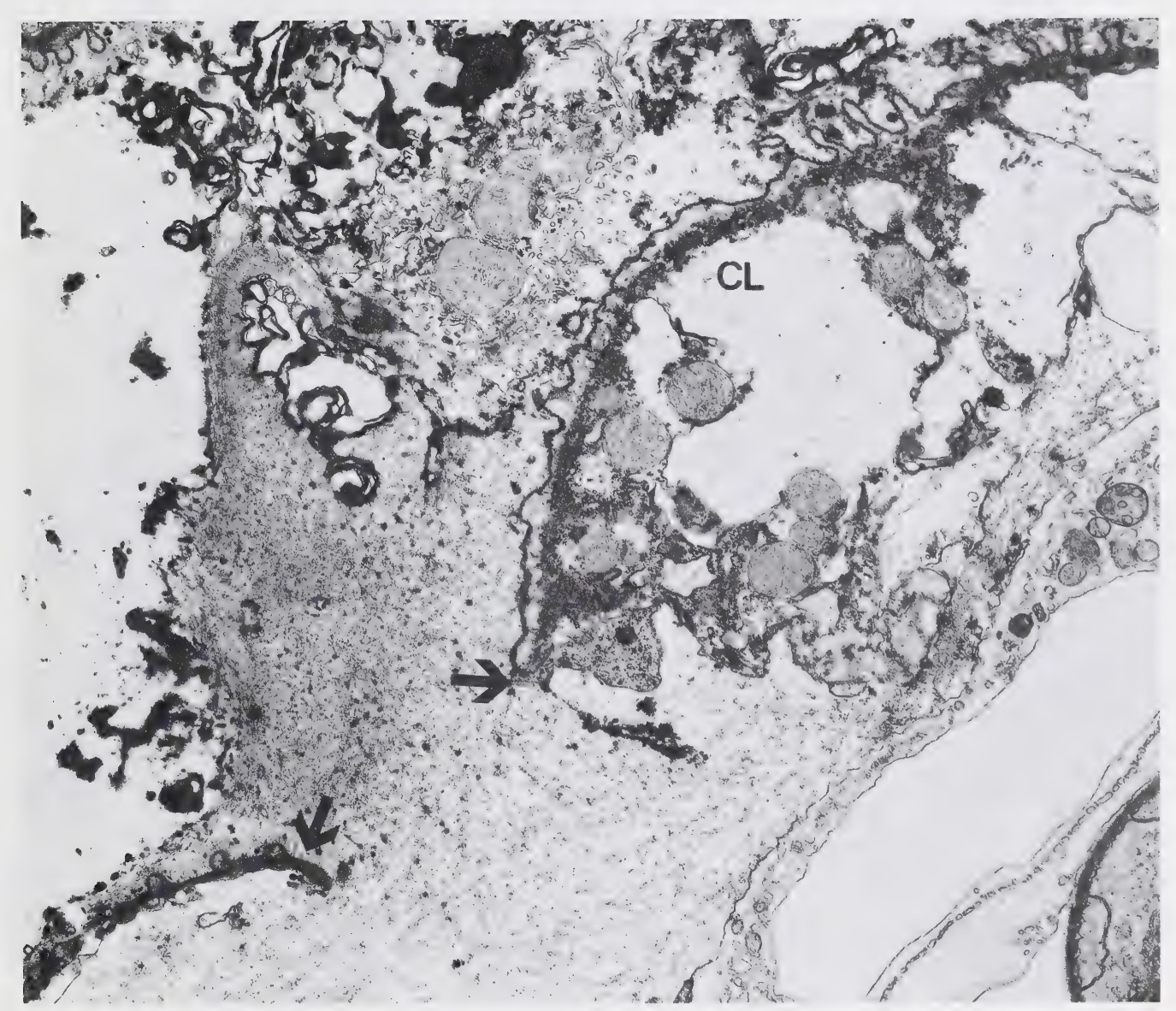

Figure 13. Electron micrograph of a gill secondary lamellae from a fish exposed to $10 \mathrm{ppm} \mathrm{H}-1137$. Note the rupture of the pavement epithelial cell layer (arrows) with escape of cytoplasmic organelle from a chloride cell (CL) to the outside. Uranyl acetate and lead citrate, $x$ 12,000. 


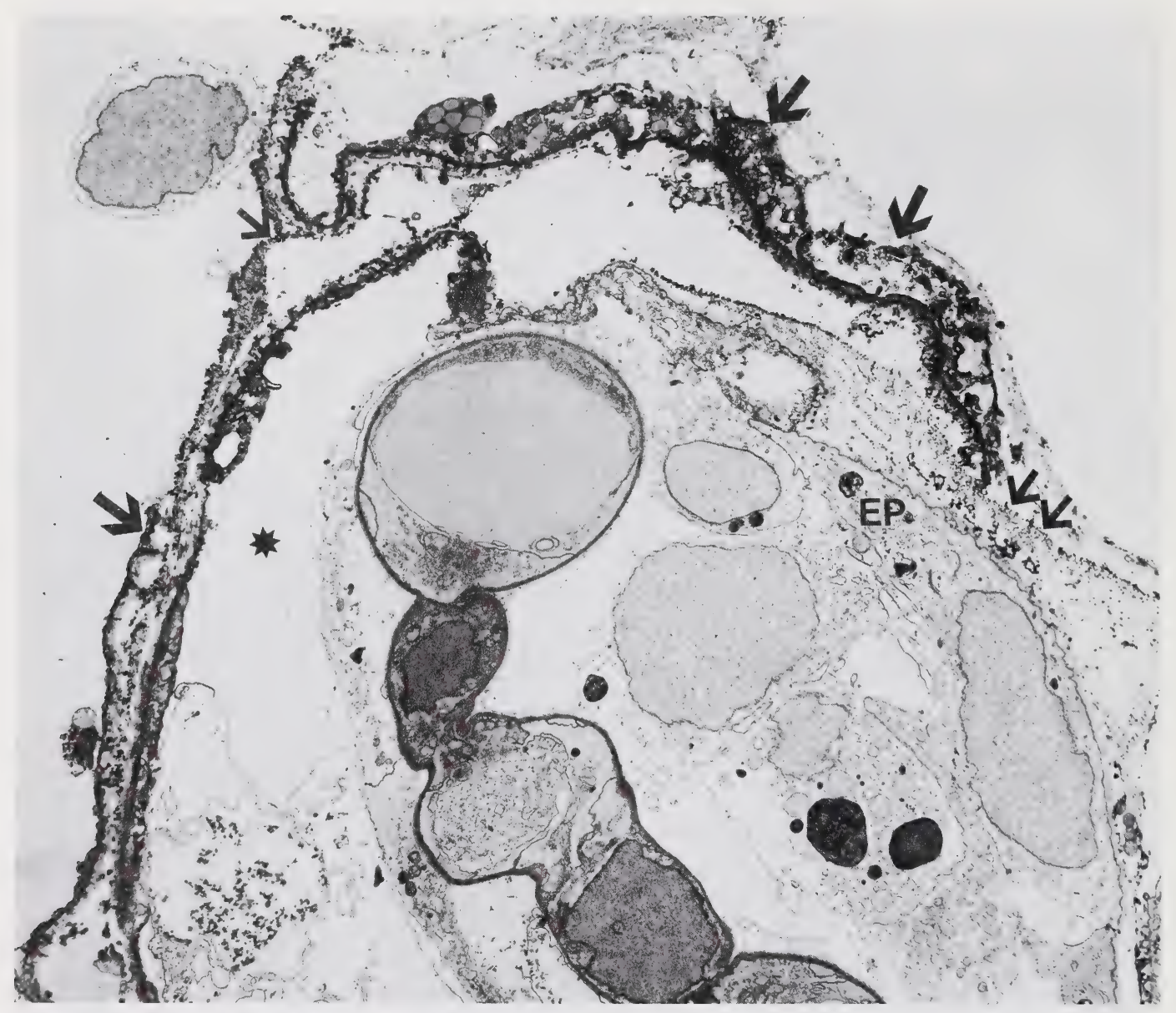

Figure 14. Electron micrograph of a secondary lamellae from a fish exposed to $10 \mathrm{ppm} \mathrm{H}-1137$. Note diffuse necrosis of the pavement epithelial cells (large arrows), rupture of the surface epithelium (small arrows), marked interstitial edema $\left({ }^{*}\right)$ and marked swelling of the undifferentiated epithelial cells (EP). Uranyl acetate and lead citrate, $\times 4000$. 


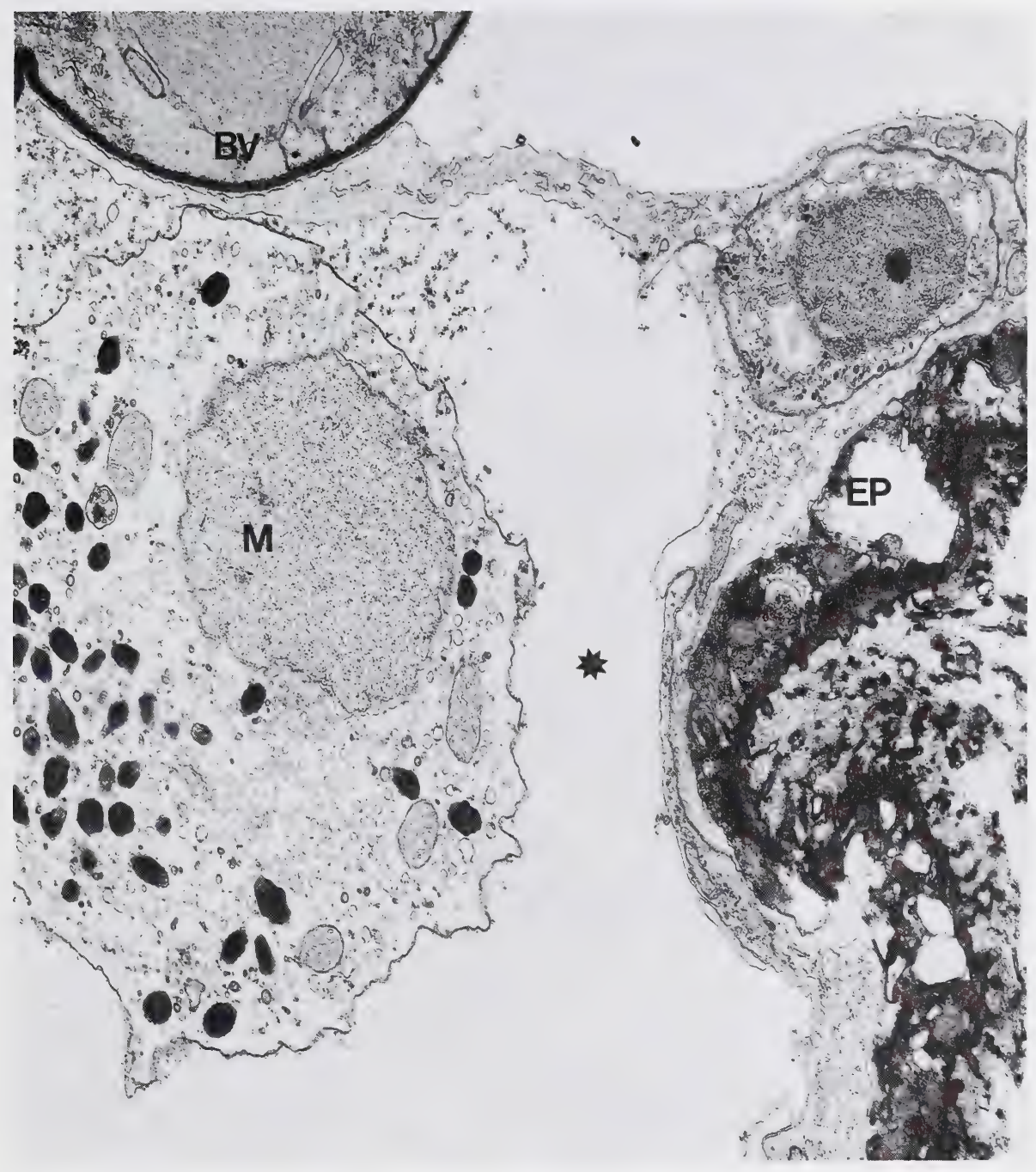

Figure 15. Electron micrograph of a secondary lamellae from a fish exposed to $10 \mathrm{ppm} \mathrm{H}-1137$. Note the marked edema of the interstitium $\left(^{*}\right)$ and swelling of a macrophage (M), (EP) necrotic pavement epithelial cell, (BV) blood vessel. Uranyl acetate and lead citrate, $x$ 10,000. 


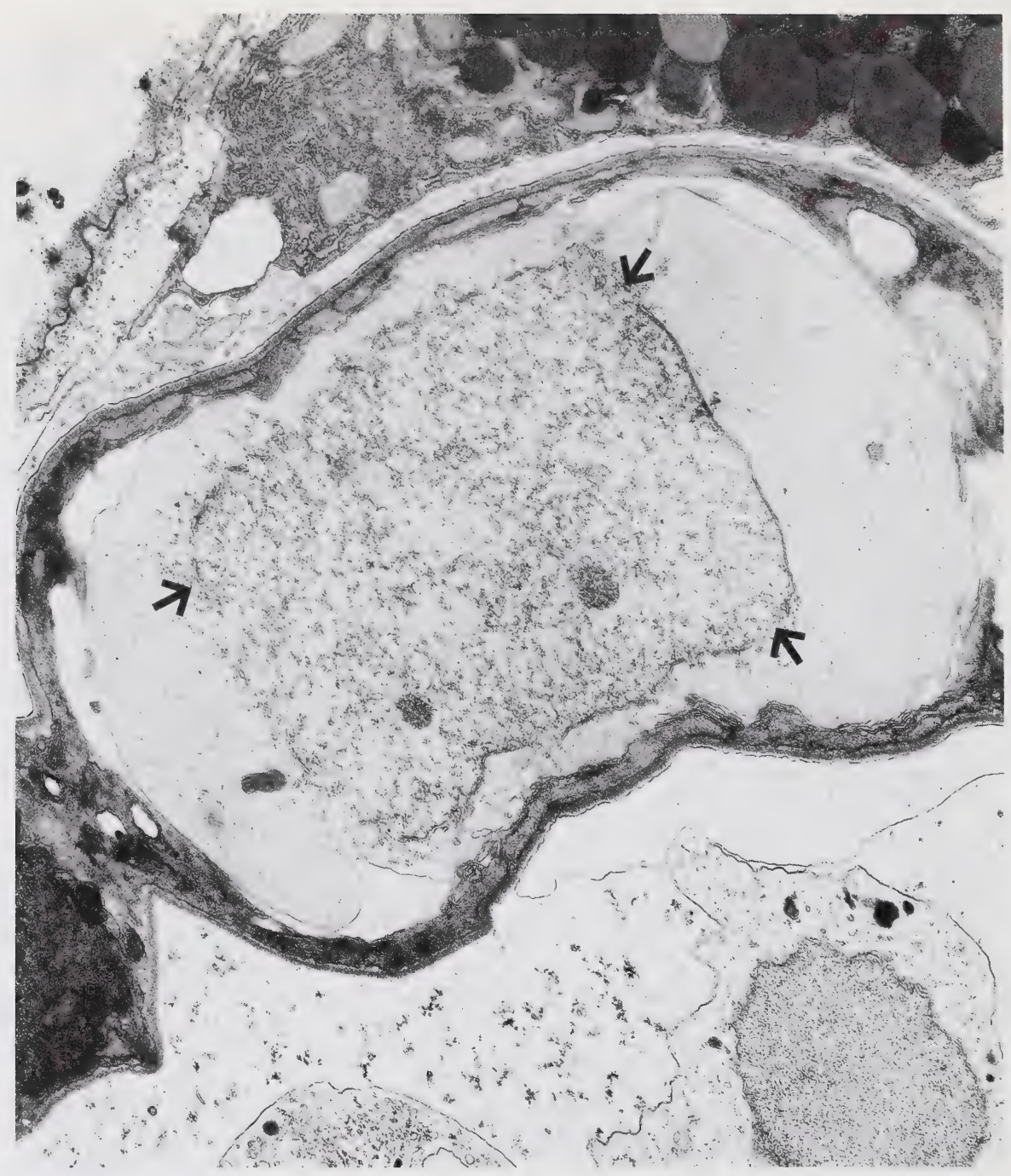

Figure 16. Electron micrograph of a secondary lamellae blood vessel from a fish exposed to $10 \mathrm{ppm} \mathrm{H-1137.} \mathrm{Note} \mathrm{the}$ disrupted nuclear envelope (arrows) of the red blood cell. Uranyl acetate and lead citrate, $x$ 10,000. 


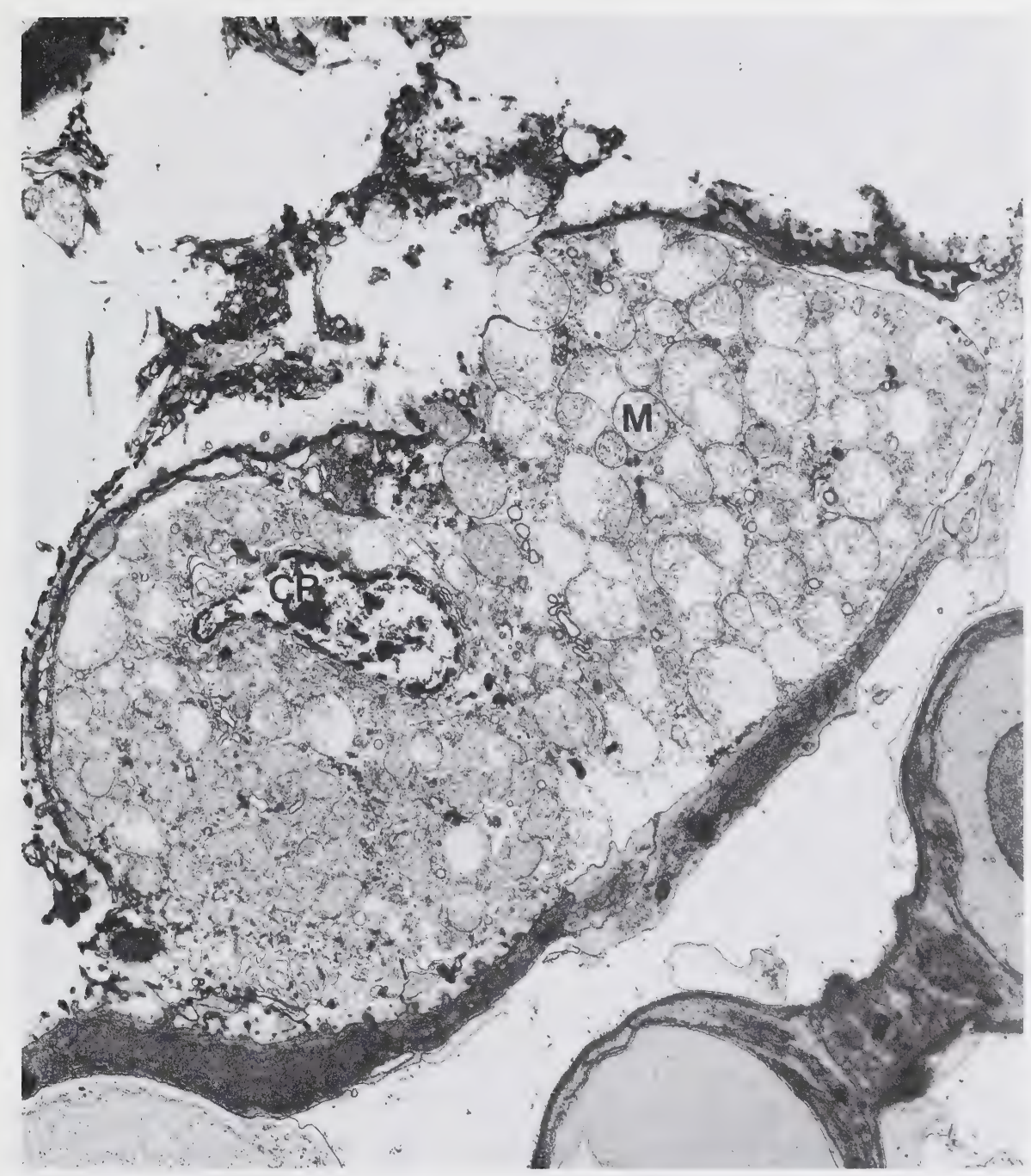

Figure 17. Electron micrograph of a chloride cell from a fish exposed to $10 \mathrm{ppm} \mathrm{H}-1137$. Note marked swelling of the mitochondria (M) with separation of their cristae, condensation and margination of the nuclear chromatin (CR) and disruption of the surface plasma membrane. Uranyl acetate and lead citrate, $x 6000$. 


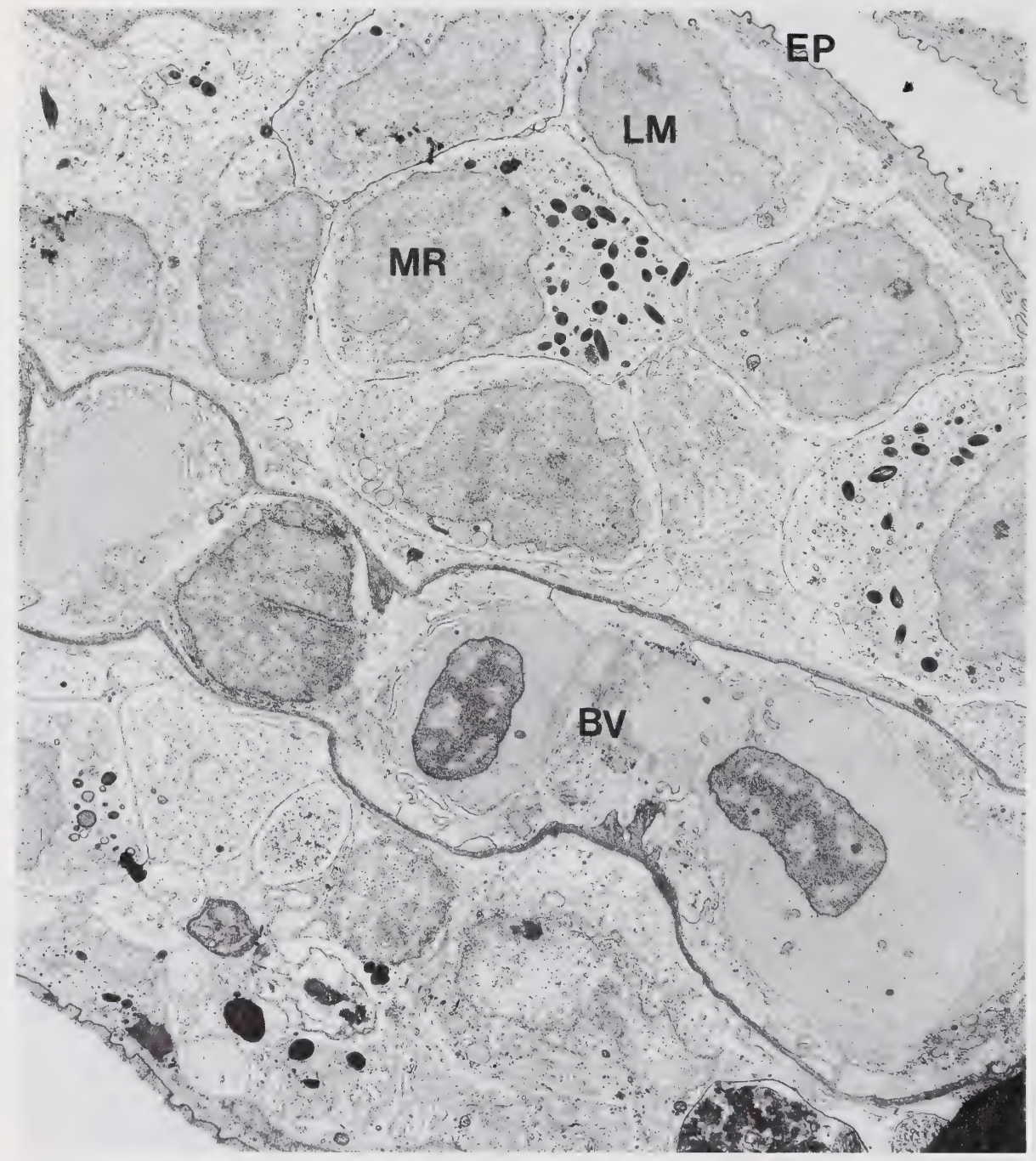

Figure 18. Electron micrograph of a secondary lamellae from a fish exposed to $0.5 \mathrm{ppm} \mathrm{H}-1137$ for 96 hours. Note many macrophages (MR) and lymphocytes (LM) infiltrated between the pavement epithelial cells (EP) and the underlying blood vessels (BV). Uranyl acetate and lead citrate, x 5000 . 


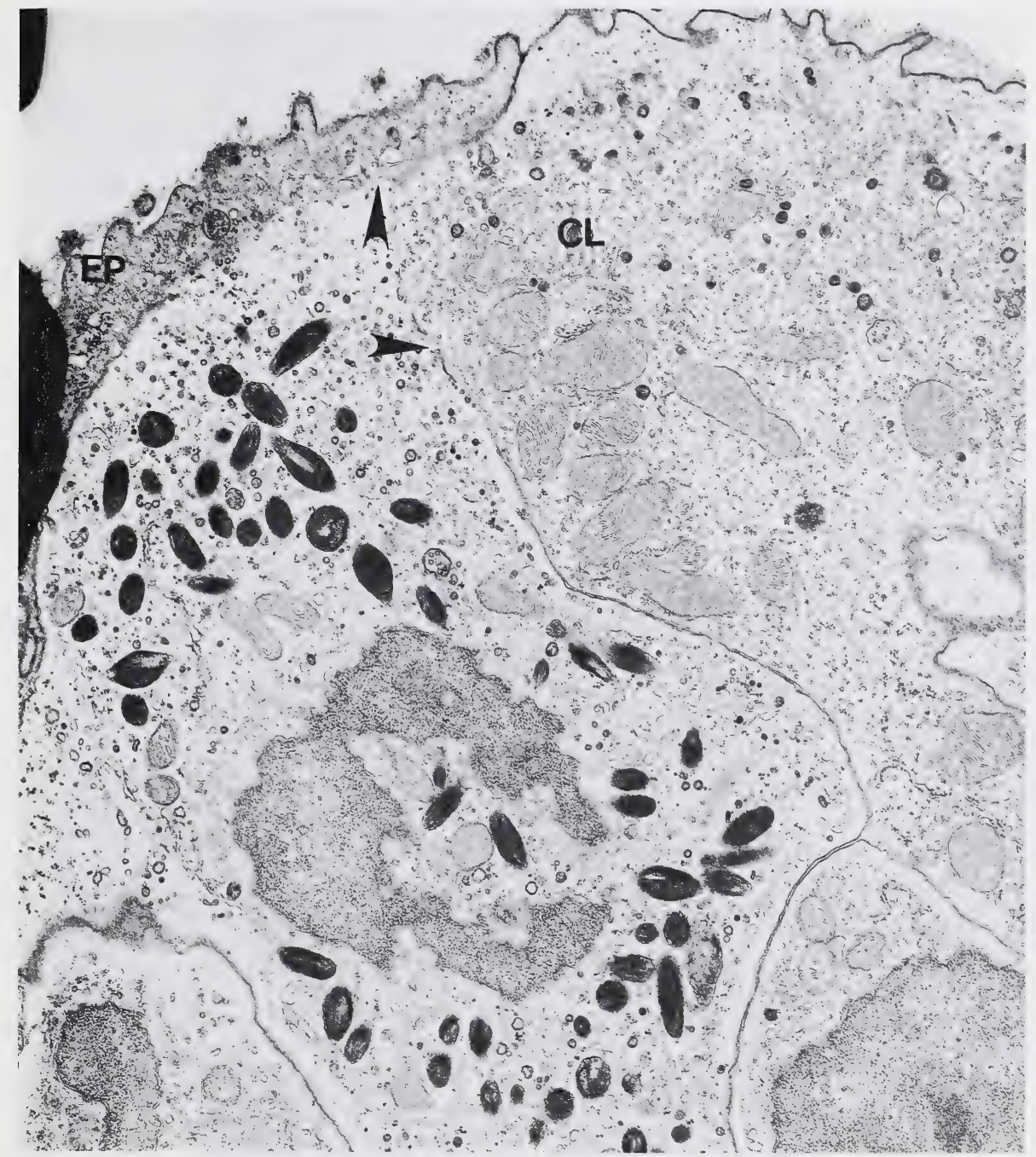

Figure 19. Electron micrograph of a secondary lamellae from a fish exposed to $0.5 \mathrm{ppm} \mathrm{H}-1137$ for 96 hours. Note the fenestration in the macrophage plasma membrane (arrow heads) adjacent to a chloride cell (CL) and a pavement epithelial cell (EP). Uranyl acetate and lead citrate, $\times 12,000$. 


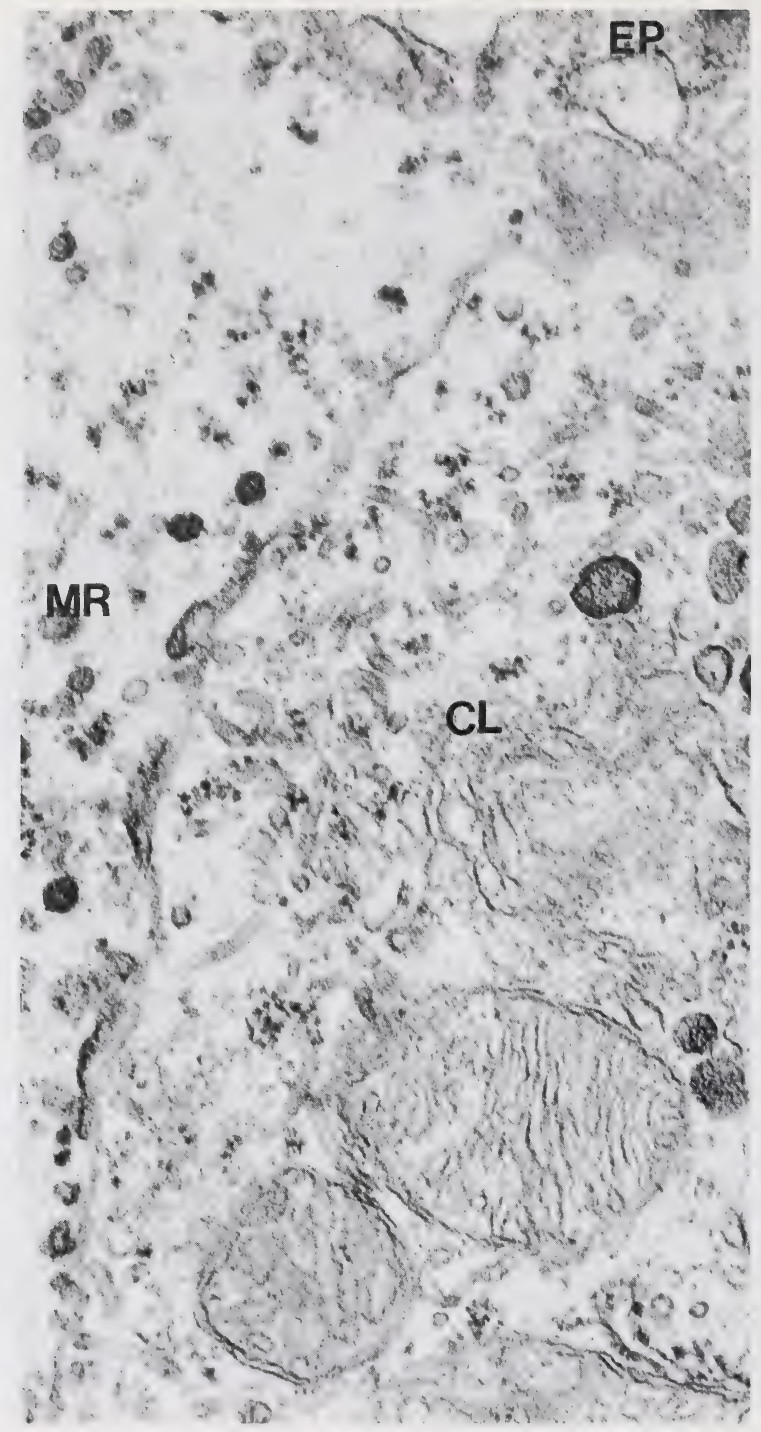

Figure 20. Higher magnification of Figure 19. Note the plasma membranes fenestration between macrophage (MR), chloride cell (CL) and pavement epithelial cell (EP). Uranyl acetate and lead citrate, x 50,000. 


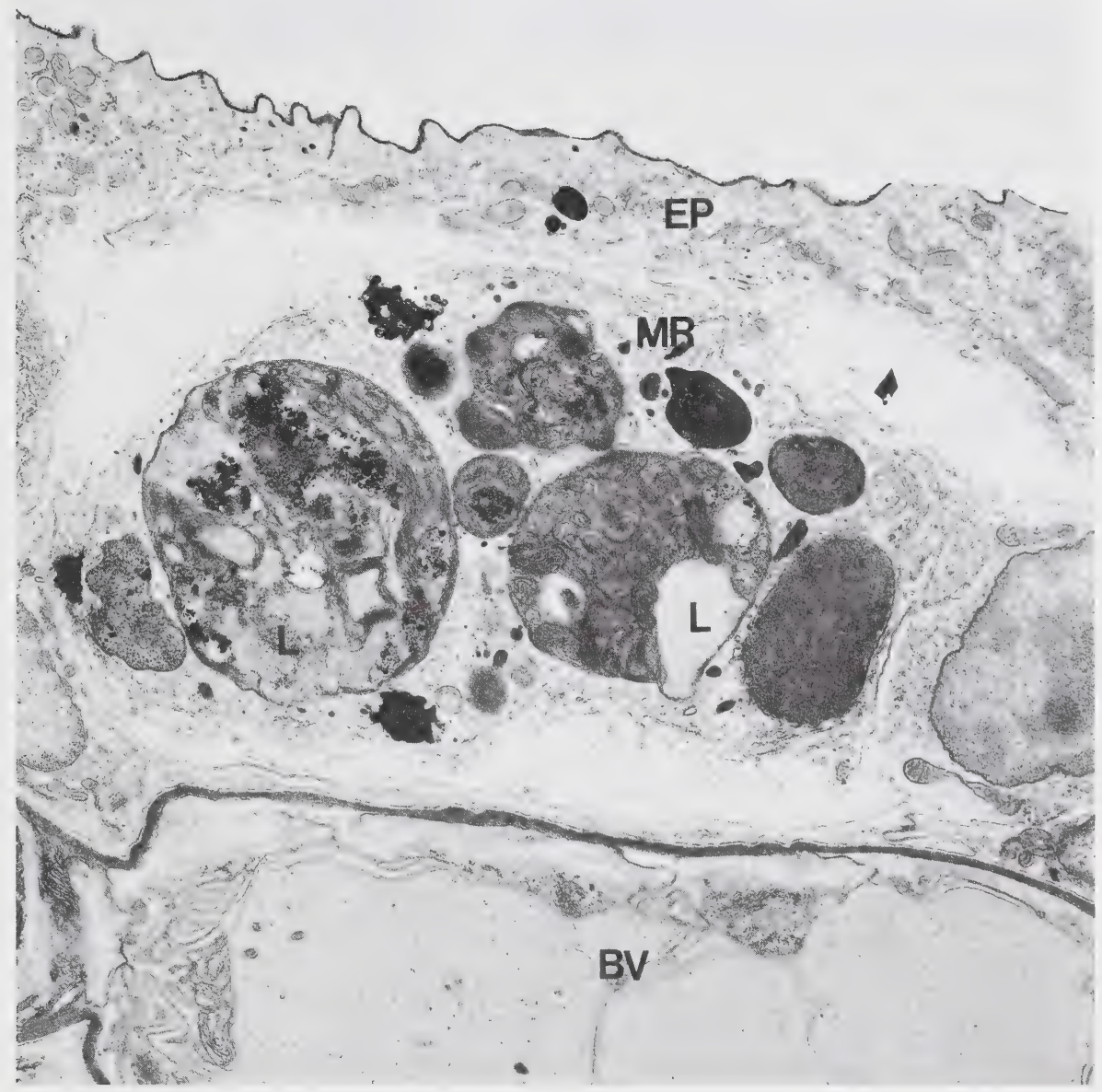

Figure 21. Electron micrograph of a secondary lamellae from a fish 192 hours after exposure to $0.5 \mathrm{ppm} \mathrm{H}-1137$. Note a cytoplasm of a macrophage (MR) filled with large phagolysosomes (L), (BV) blood vessel, (EP) pavement epithelial cell. Uranyl acetate and lead citrate, $x$ 8,000 . 
Appendix II. Histopathological findings in small fish (Acute Study) H-1137 + Untreated Effluent Pathology \#551-84

Aquatic \#17-84

\begin{tabular}{|c|c|c|c|c|c|c|c|c|c|c|}
\hline & \multicolumn{4}{|c|}{ Gill Lesions } & \multicolumn{5}{|c|}{ Skin Lesions } & \multirow[b]{2}{*}{ Comments } \\
\hline Concentration & $\bar{N}$ & MI & MO & MR SR & $\bar{N}$ & MI & $\mathrm{MO}$ & MR & SR & \\
\hline Control & 1 & 1 & & 3 & 5 & & & & & \\
\hline $1 \mathrm{mg} / \mathrm{L}$ & & 1 & 2 & 2 & 3 & 1 & 1 & & & \\
\hline $10 \mathrm{mg} / \mathrm{L}$ & 1 & 1 & 3 & & 5 & & & & & \\
\hline $50 \mathrm{mg} / \mathrm{L}$ & & 1 & 2 & 1 & 5 & & & & & \\
\hline $100 \mathrm{mg} / \mathrm{L}$ & & 1 & 2 & & 3 & & & & & \\
\hline $150 \mathrm{mg} / \mathrm{L}$ & & 3 & & & 3 & & & & & \\
\hline
\end{tabular}

$$
\begin{aligned}
& N=\text { Normal } \\
& M I=\text { Mild } \\
& M O=\text { Moderate } \\
& M R=\text { Marked } \\
& S R=\text { Severe }
\end{aligned}
$$


Appendix II. Continued.

H-1142 + Untreated Effluent

Pathology \#552-84

Aquatic \#18-84

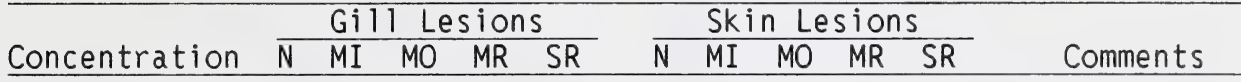

\section{Control}

Effluent only 23

5

$\begin{array}{lllllll}1 \mathrm{mg} / \mathrm{L} & 2 & 1 & 2 & 3 & 1 & 1\end{array}$

$\begin{array}{lllll}10 \mathrm{mg} / \mathrm{L} & 2 & 5 & & \text { Hepatic vacuola- } \\ & \text { tion Mild } 1, \\ & \text { Normal } 4\end{array}$

$50 \mathrm{mg} / \mathrm{L} \quad 1 \quad 3 \quad 1 \quad 5$

$100 \mathrm{mg} / \mathrm{L} \quad 2 \quad 1 \quad 2 \quad 5$

$150 \mathrm{mg} / \mathrm{L} \quad 4 \quad 1$

Hepatic vacuolation, Moderate

1, Normal 4

$$
\begin{aligned}
& N=\text { Normal } \\
& M I=\text { Mild } \\
& M O=\text { Moderate } \\
& M R=\text { Marked } \\
& S R=\text { Severe }
\end{aligned}
$$


Appendix II. Continued

H-1121 + Untreated Effluent

Pathology \#438-84

Aquatic \#10-84

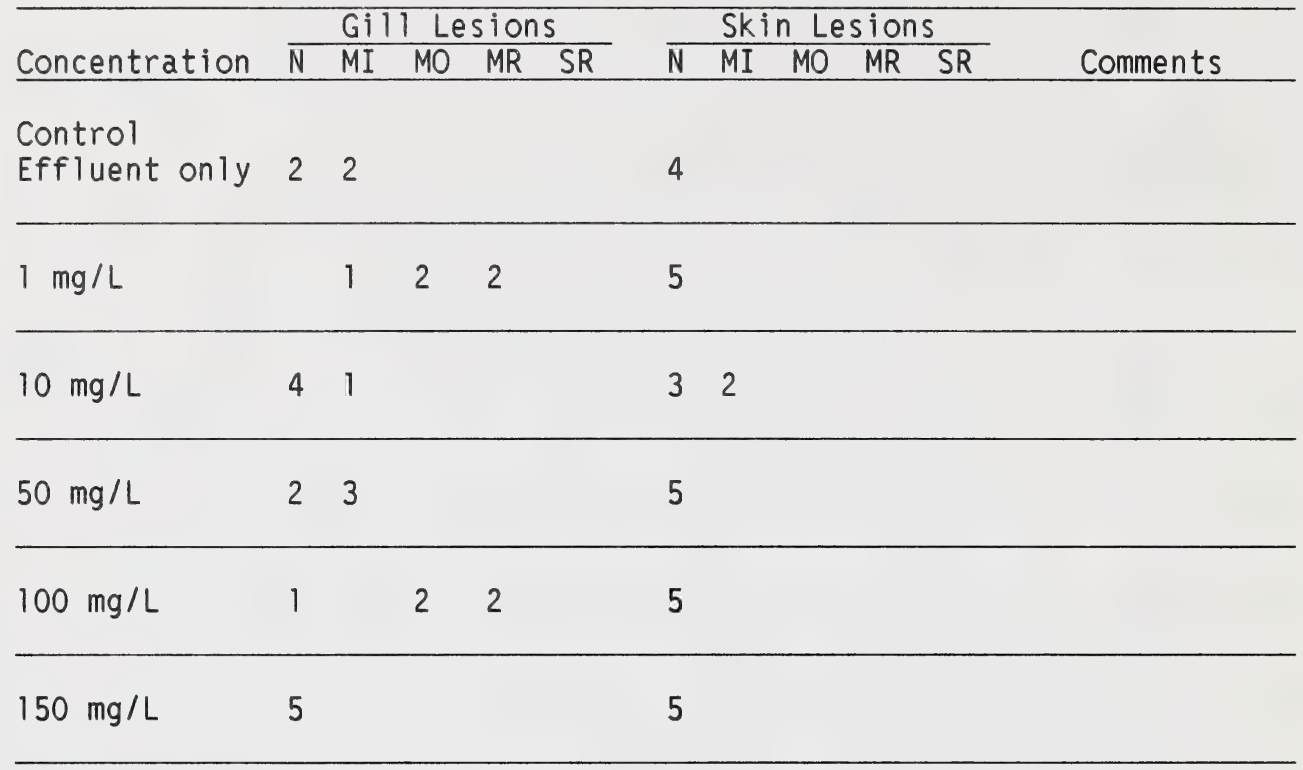

$\mathrm{N}=$ Normal

$M I=M i l d$

$\mathrm{MO}=$ Moderate

$M R=$ Marked

$S R=$ Severe 
Appendix II. Continued

$\mathrm{H}-1110$ + Untreated Effluent

Pathology \#437-84

Aquatic \#9-84

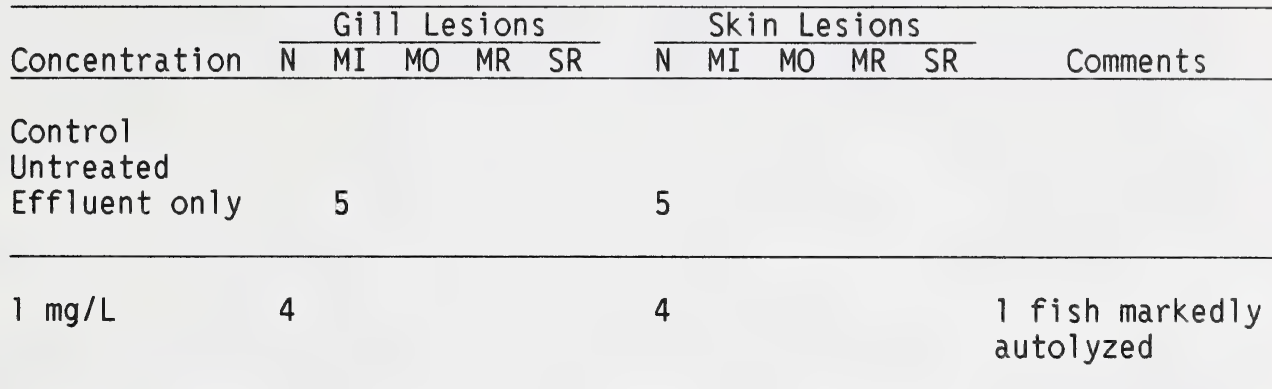

$10 \mathrm{mg} / \mathrm{L} \quad 3 \quad 3 \quad 3 \quad 2$

$50 \mathrm{mg} / \mathrm{L} \quad 4 \quad 1 \quad 1 \quad 2 \quad 1 \quad 3$

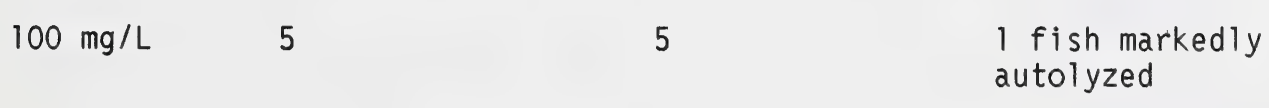

$150 \mathrm{mg} / \mathrm{L} \quad 2 \quad 2 \quad 2 \quad 4 \quad 2$

$N=$ Normal

$M I=M i l d$

$\mathrm{MO}=$ Moderate

$M R=$ Marked

$S R=$ Severe 


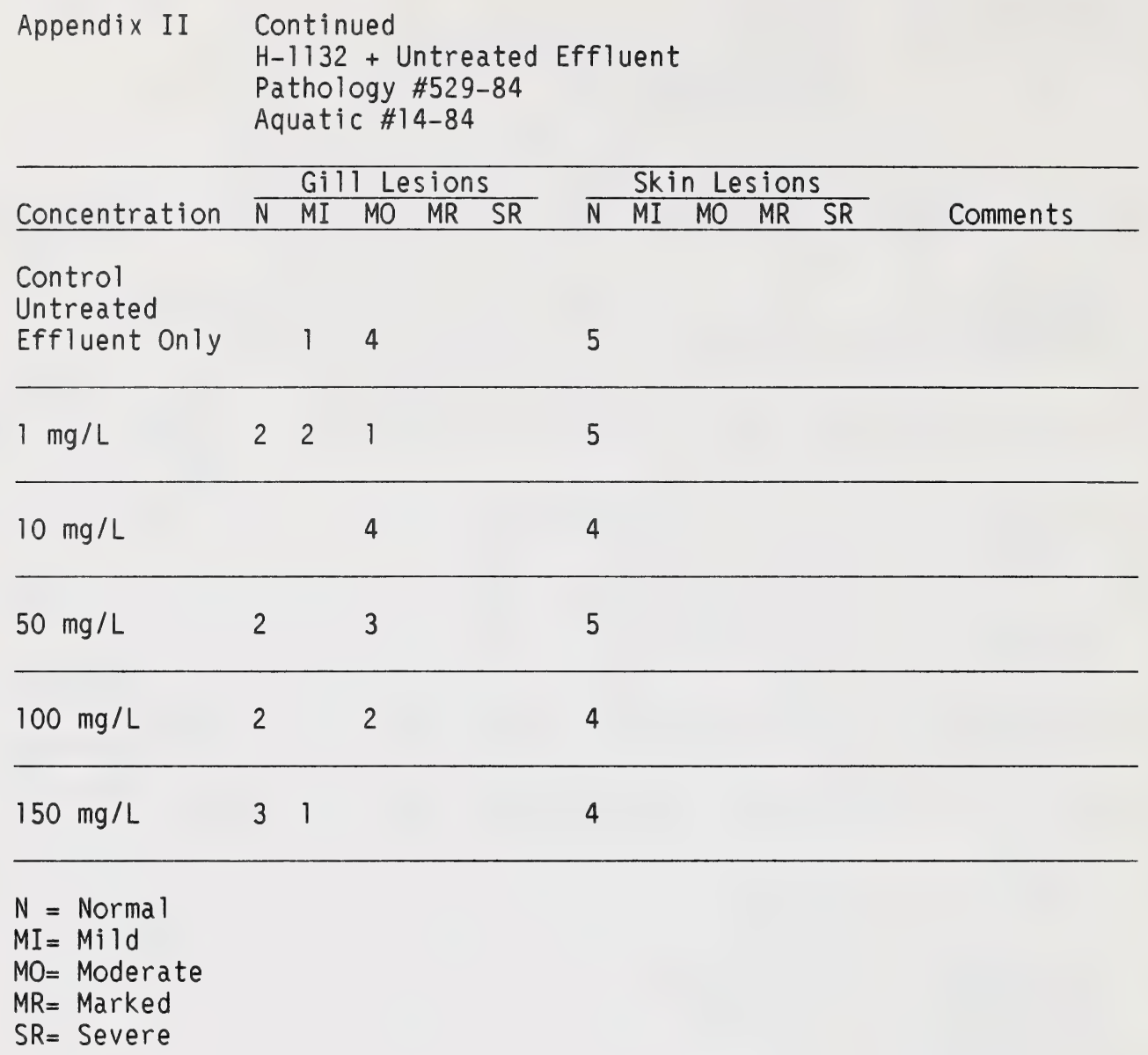


Appendix II Continued

$\mathrm{H}-1123+$ Untreated Effluent

Pathology \#528-84

Aquatic \#13-84

Gill Lesions Skin Lesions

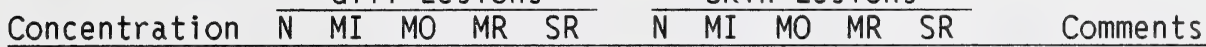

Control

Untreated

Effluent Only 130115

$\begin{array}{lllll}1 \mathrm{mg} / \mathrm{L} & 2 & 1 & 1 & 4\end{array}$

$10 \mathrm{mg} / \mathrm{L} \quad 3 \quad 2 \quad 5$

Hepatic vacuolation, mild 1 , moderate 2, normal 2

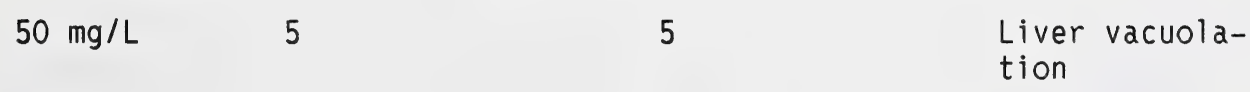

$100 \mathrm{mg} / \mathrm{L}$

32

5

$150 \mathrm{mg} / \mathrm{L}$

41

5

$\mathrm{N}=$ Normal

$M I=M i l d$

$M O=$ Moderate

$M R=$ Marked

$S R=$ Severe 


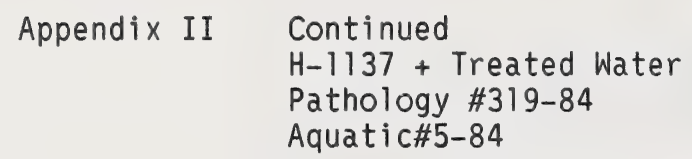

\begin{tabular}{|c|c|c|c|c|c|c|c|c|c|}
\hline Concentration & $\bar{N}$ & $\frac{G i}{M I}$ & $\frac{1 L}{M O}$ & $\frac{\text { sions }}{M R}$ & $\frac{S}{S R}$ & $\bar{N}$ & $\frac{S k}{M I}$ & $\begin{array}{l}n \text { Lesions } \\
\text { MO MR SR }\end{array}$ & Comments \\
\hline Control & 1 & 2 & 2 & & & 1 & 2 & 1 & \\
\hline $1 \mathrm{mg} / \mathrm{L}$ & 3 & 2 & & & & 1 & 2 & 1 & \\
\hline $10 \mathrm{mg} / \mathrm{L}$ & 1 & 1 & 1 & & 2 & 3 & 2 & & \\
\hline $50 \mathrm{mg} / \mathrm{L}$ & & & & 5 & & 3 & 2 & & \\
\hline $100 \mathrm{mg} / \mathrm{L}$ & & & & & 5 & 2 & 1 & 2 & \\
\hline $150 \mathrm{mg} / \mathrm{L}$ & & & & & 5 & 1 & 2 & 2 & $\begin{array}{l}\text { Oral lesions, } \\
\text { moderate } 2 \text {, mild } \\
1 \text {, normal i }\end{array}$ \\
\hline
\end{tabular}

$\mathrm{N}=$ Normal

$M I=M i l d$

$M O=$ Moderate

$M R=$ Marked

$S R=$ Severe 
Appendix II Continued

$\mathrm{H}-1142$ + Treated Water

Pathology \#320-84

Aquatic \#6-84

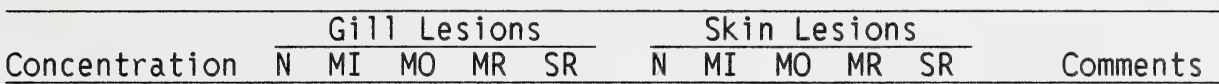

Control

23

41

$1 \mathrm{mg} / \mathrm{L}$

14

221

$10 \mathrm{mg} / \mathrm{L}$

32

32

$50 \mathrm{mg} / \mathrm{L}$

221

32

$100 \mathrm{mg} / \mathrm{L}$

$\begin{array}{lll}1 & 3 & 1\end{array}$

32

$150 \mathrm{mg} / \mathrm{L}$

122

32

Oral lesions, moderate 2 ,

mild 1 , normal 1

$\mathrm{N}=$ Normal

$M I=M i l d$

$\mathrm{MO}=$ Moderate

$M R=$ Marked

$S R=$ Severe 
Appendix II. Continued

$\mathrm{H}-1121$ + Treated Water

Pathology \#51-84

Aquatic \#2-84

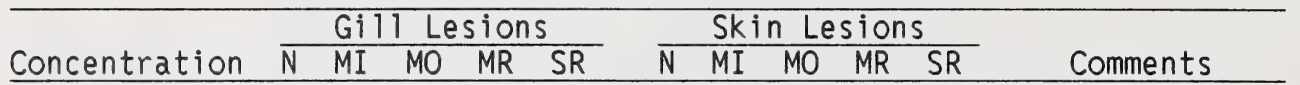

Control

\begin{tabular}{|c|c|c|c|}
\hline $1 \mathrm{mg} / \mathrm{L}$ & 23 & 32 & $\begin{array}{l}\text { Oral lesions, } 3 \\
\text { mild, } 2 \text { normal }\end{array}$ \\
\hline
\end{tabular}

$10 \mathrm{mg} / \mathrm{L} \quad 5 \quad 23$

$50 \mathrm{mg} / \mathrm{L} \quad 5 \quad 1 \quad 4$

$100 \mathrm{mg} / \mathrm{L} \quad 4 \quad 1 \quad 3 \quad 3$

$150 \mathrm{mg} / \mathrm{L} \quad 5$

$N=$ Normal
$M I=$ Mild
$M O=$ Moderate
$M R=$ Marked
$S R=$ Severe 
Appendix II. Continued

$\mathrm{H}-1110$ + Treated Water

Pathology \#50-84

Aquatic \#1-84

\begin{tabular}{llllllll}
\hline & \multicolumn{4}{c}{ Gill Lesions } & & \multicolumn{3}{c}{ Skin Lesions } & \\
\cline { 3 - 4 } Concentration & MI & MO & MR & SR & & MI MO MR SR & Comments \\
\hline
\end{tabular}

Control

Treated Water

Only

5

5

$1 \mathrm{mg} / \mathrm{L}$

5

32

$10 \mathrm{mg} / \mathrm{L}$

5

23

$50 \mathrm{mg} / \mathrm{L}$

5

14

$100 \mathrm{mg} / \mathrm{L}$

5

122

$150 \mathrm{mg} / \mathrm{L}$

5

23

$N=$ Normal

$M I=M i l d$

$M O=$ Moderate

$M R=$ Marked

$S R=$ Severe 
Appendix II Continued

$\mathrm{H}-1132$ + Treated Water

Pathology \#209-84

Aquatic \#4-84

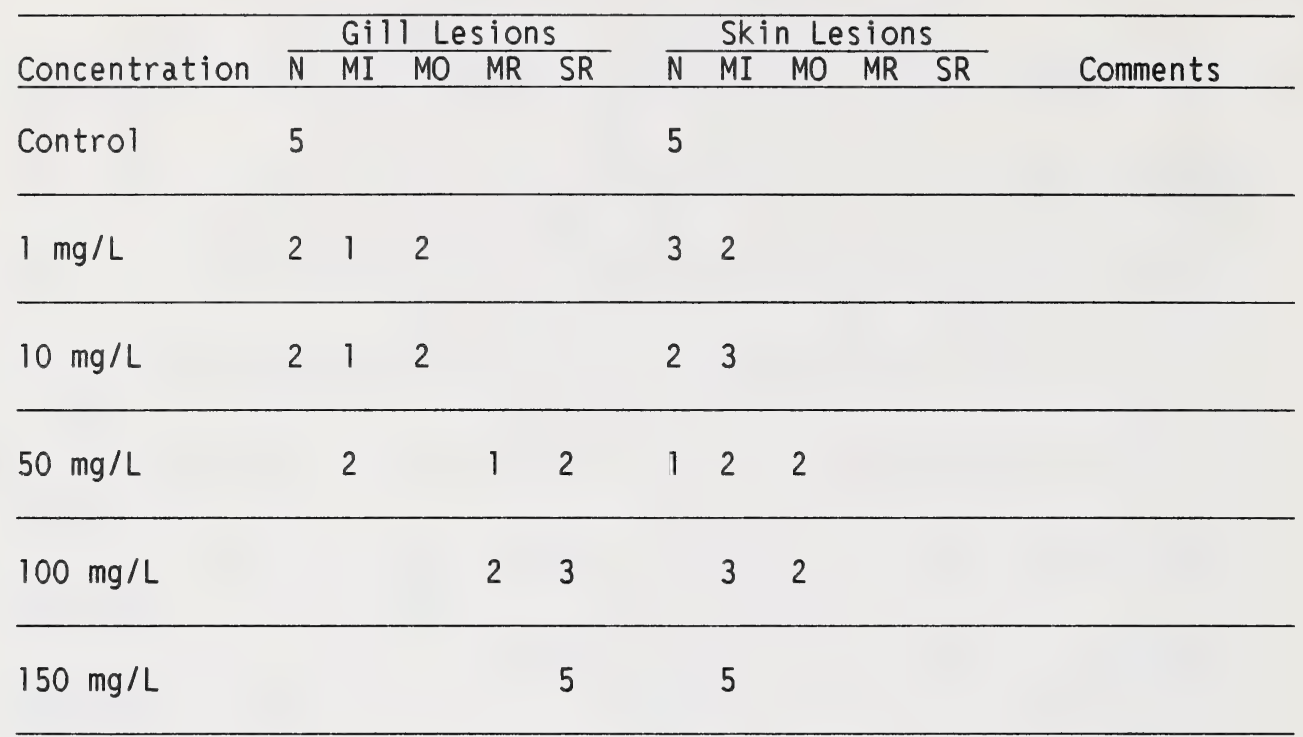

$N=$ Normal

$M I=M i l d$

$\mathrm{MO}=$ Moderate

$M R=$ Marked

$S R=$ Severe 
Appendix II. Continued

$\mathrm{H}-1123$ + Treated Water

Pathology \#208-84

Aquatic \#3-84

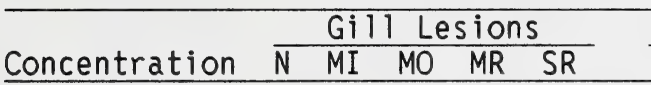

Skin Lesions

Control 5

$1 \mathrm{mg} / \mathrm{L}$

5

41

$10 \mathrm{mg} / \mathrm{L}$

5

23

$50 \mathrm{mg} / \mathrm{L}$

5

5

$100 \mathrm{mg} / \mathrm{L}$

5

41

$150 \mathrm{mg} / \mathrm{L}$

5

5

$N=$ Normal
$M I=$ Mild
$M O=$ Moderate
$M R=$ Marked
$S R=$ Severe 


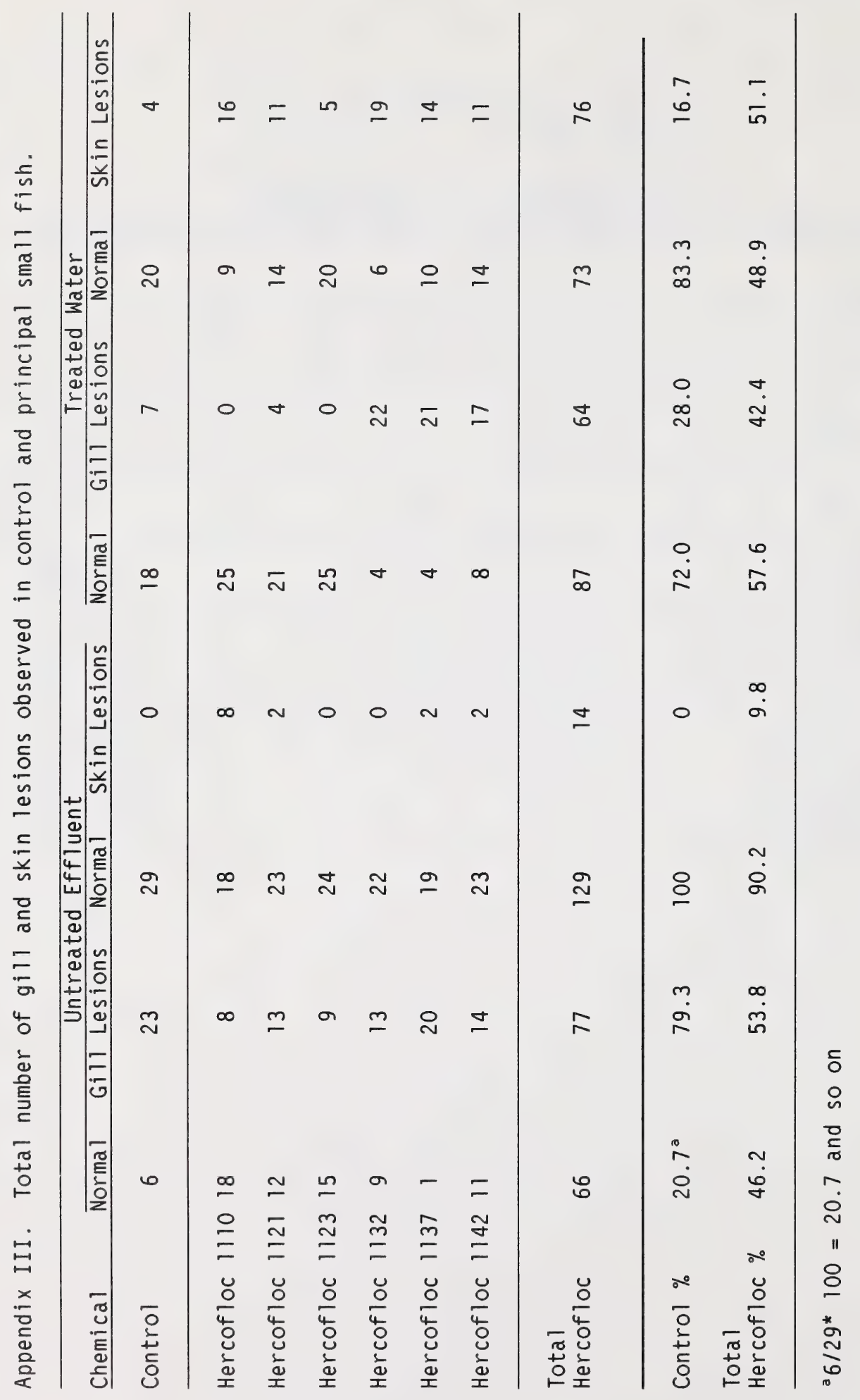




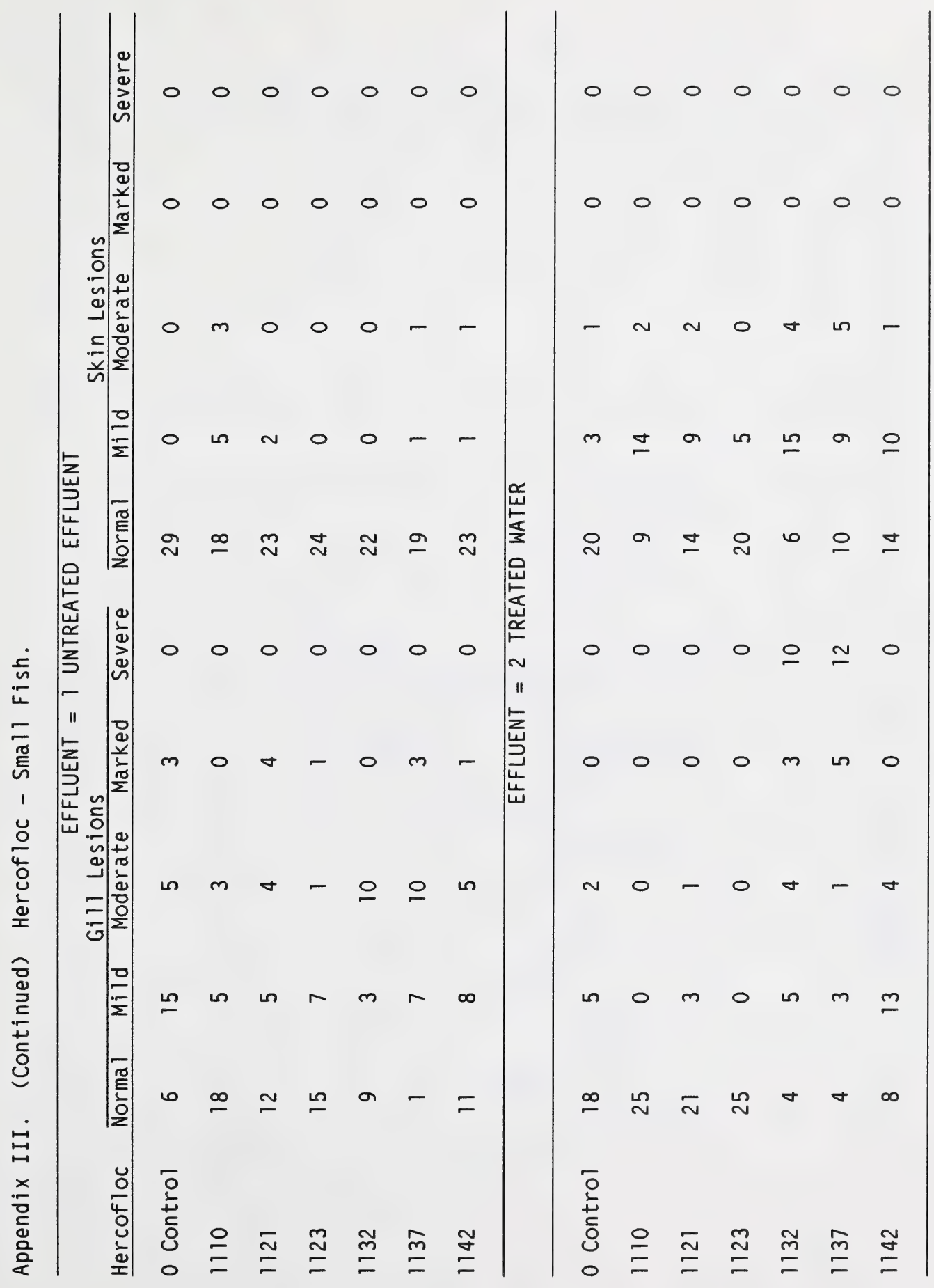




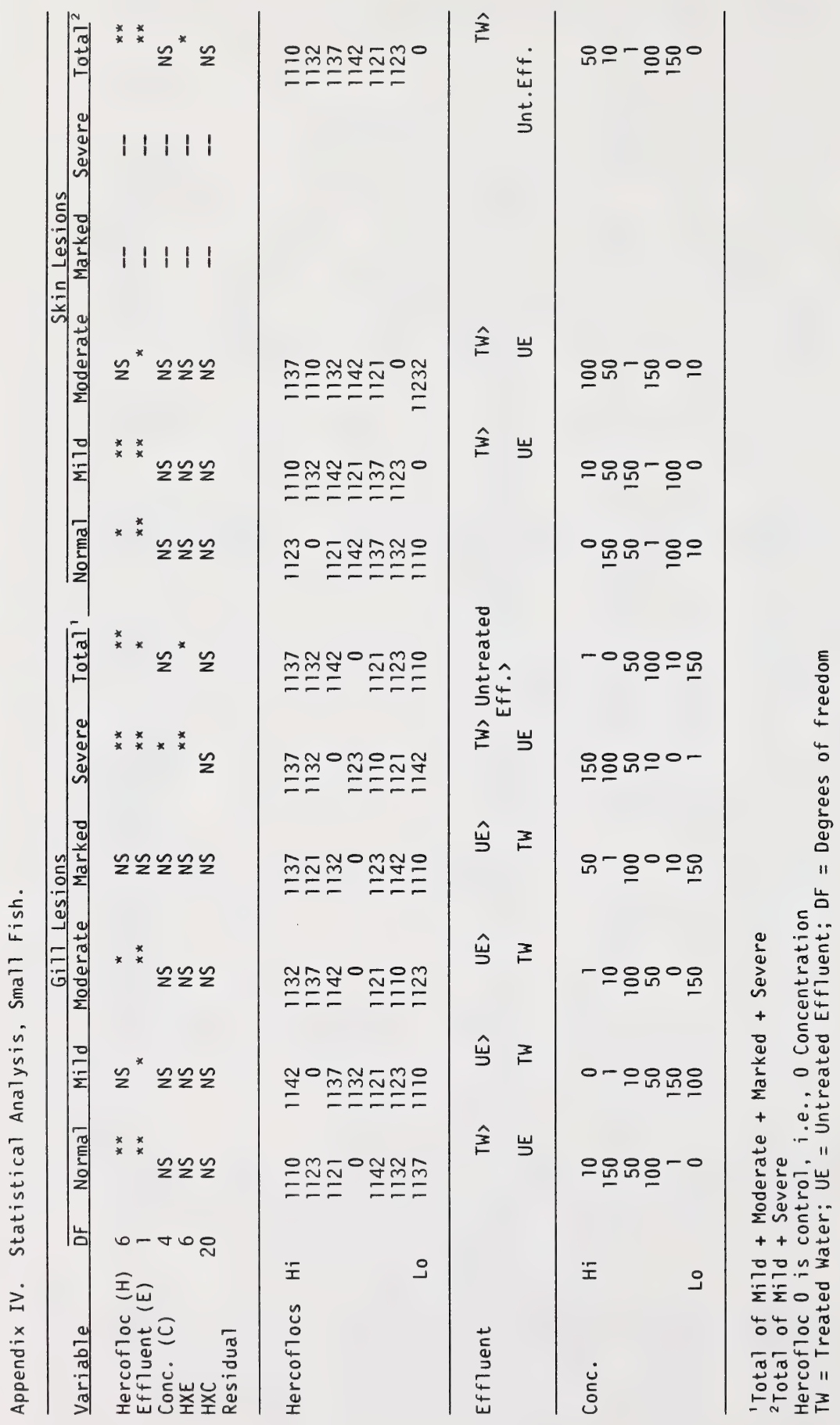




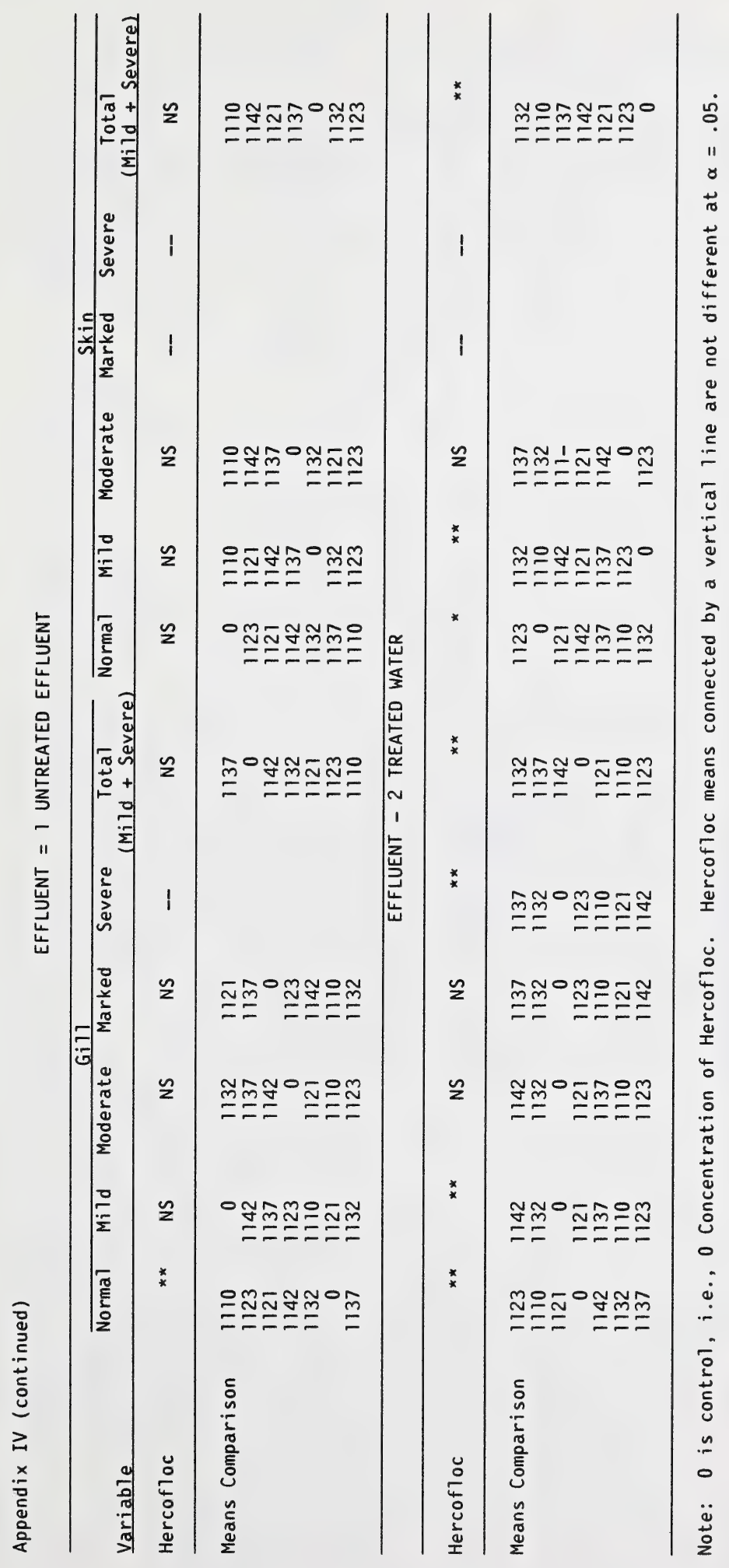




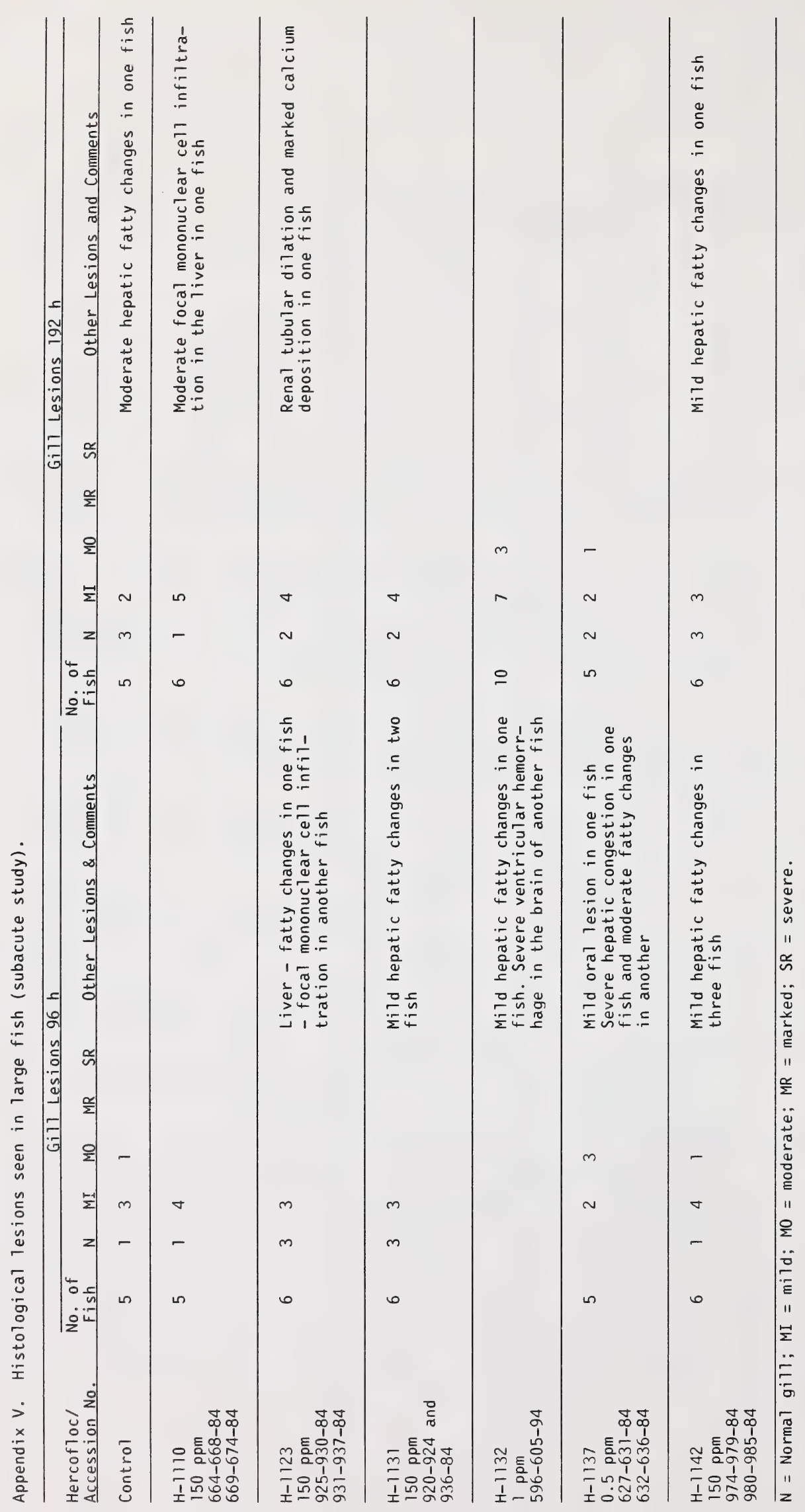


Appendix V (continued). Skin lesions in large fish (subacute study).

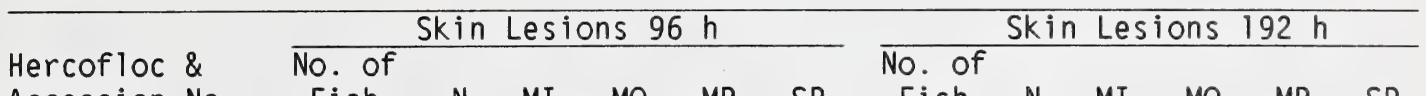

Accession No. Fish $N$ MI MO MR SR Fish N MI MO MR SR

Control

$654-658-84$
$659-663-84$

$5 \quad 3 \quad 2$

$5 \quad 1 \quad 4$

$\mathrm{H}-1110$

$150 \mathrm{ppm}$

664-668-84

$669-674-84$

5

$4 \quad 1$

$\begin{array}{lll}6 & 1 & 5\end{array}$

H-1123

$150 \mathrm{ppm}$

925-930-84

931-937-84

$\begin{array}{lll}6 & 2 & 4\end{array}$

$\begin{array}{lll}6 & 3 & 3\end{array}$

$\mathrm{H}-1131$

$150 \mathrm{ppm}$

914-919-84

920-924 and

936-84

$\begin{array}{lll}6 & 2 & 4\end{array}$

$6 \quad 1 \cdot 5$

H-1132

$1 \mathrm{ppm}$

596-605-84

$10 \quad 7 \quad 2 \quad 1$

H-1137

$0.5 \mathrm{ppm}$

627-631-84

621-636-84

$\begin{array}{llll}5 & 2 & 2 & 1\end{array}$

$\begin{array}{lll}5 & 2 & 3\end{array}$

H-1142

$150 \mathrm{ppm}$

974-979-84

980-985-84

$\begin{array}{lll}6 & 3 & 3\end{array}$

$\begin{array}{lll}6 & 4 & 2\end{array}$

$\mathrm{N}=$ Normal skin

$M I=M i l d$

$M O=$ Moderate

$M R=$ Marked

$S R=$ Severe 


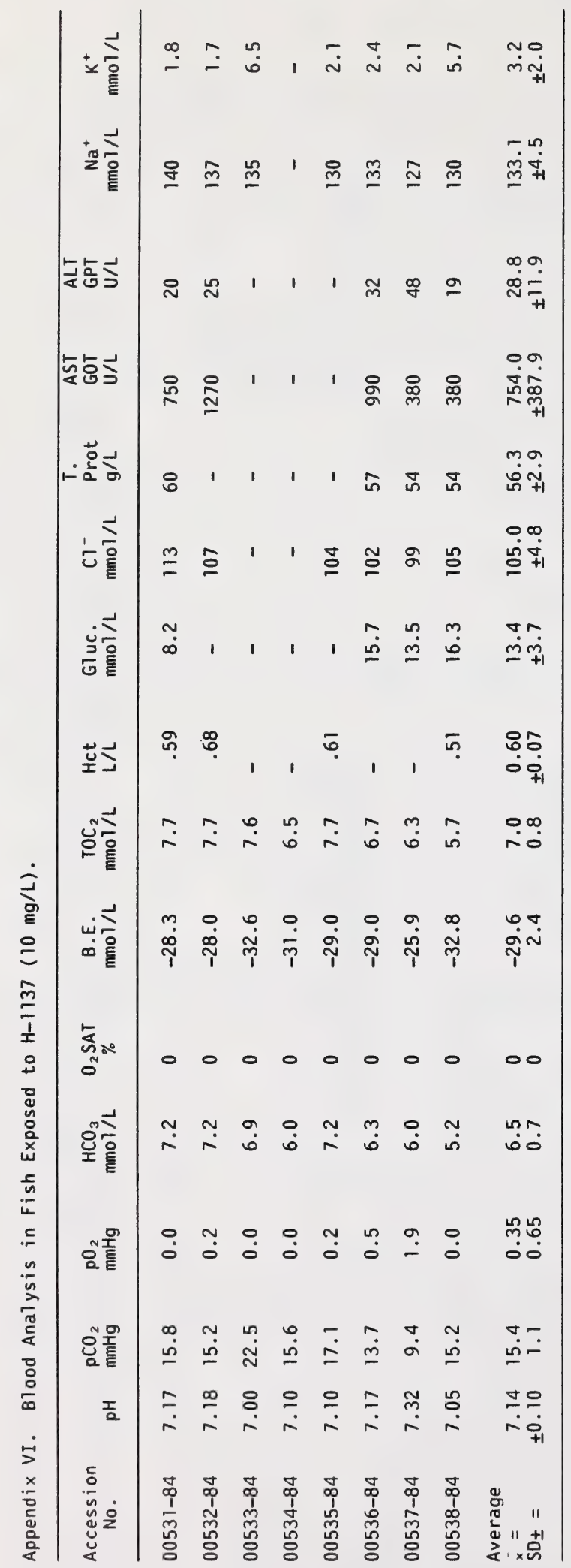




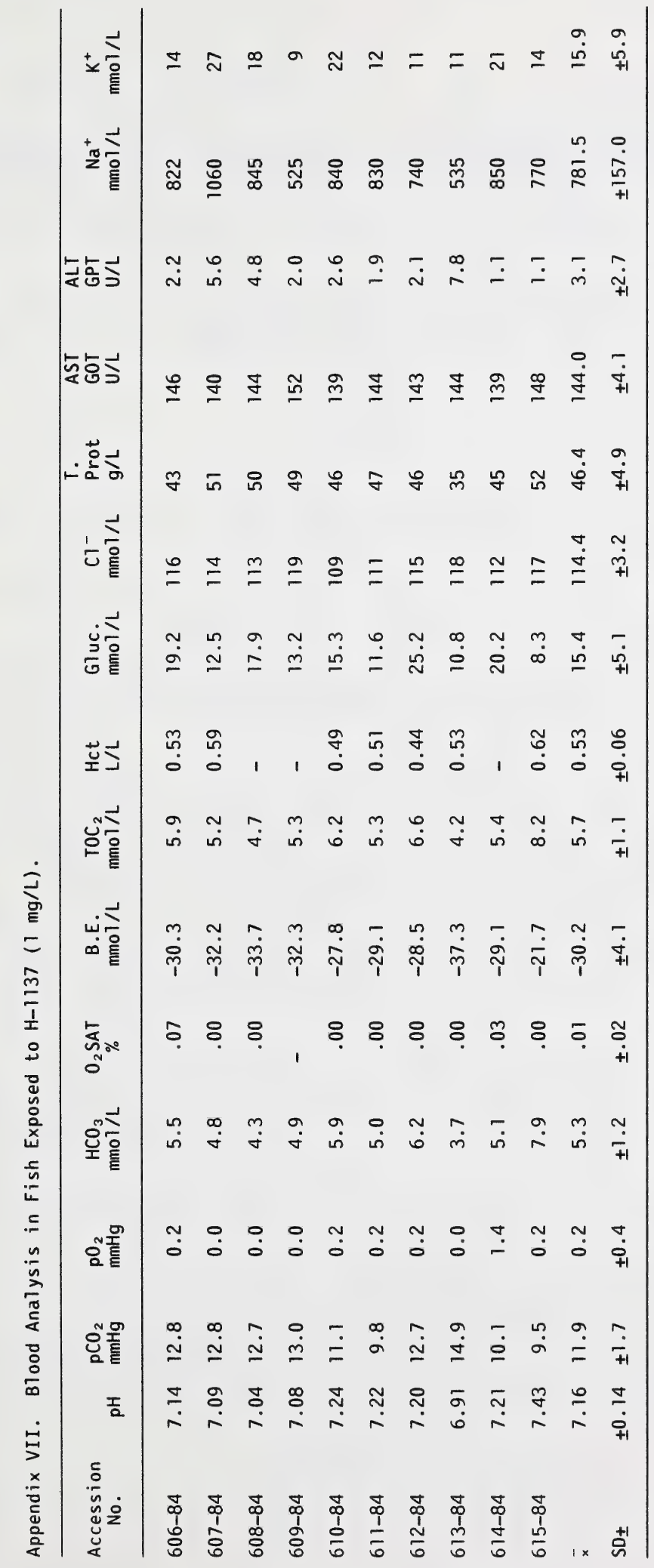


Appendix VIII. Statistical Analyses, Large Fish

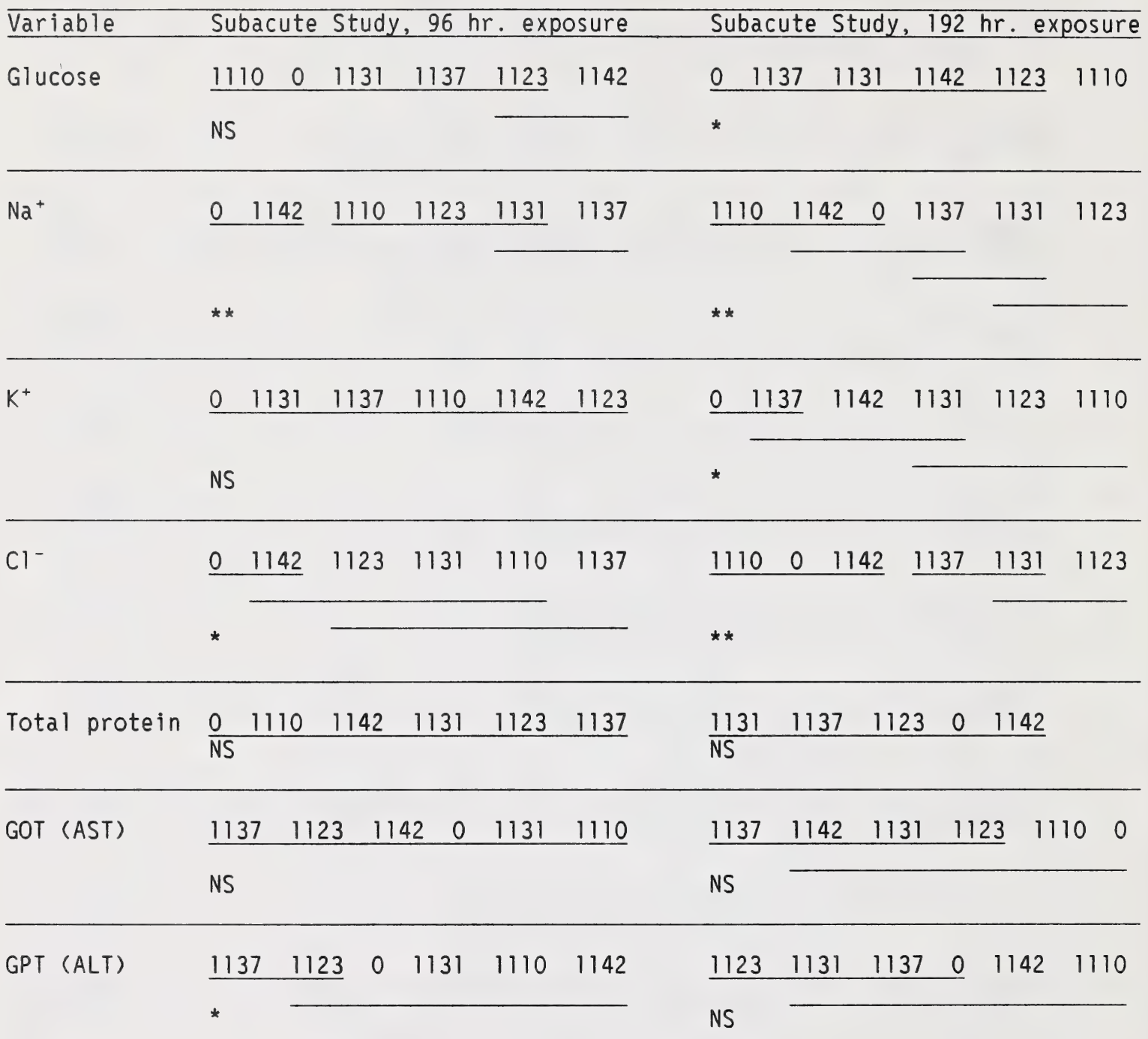

Hercofloc 0 is control.

**: Effect of Hercofloc significant at $p \leqq .01$

* : Effect of Hercofloc significant at $p \stackrel{\vdots}{=} 05$

NS: Effect of Hercofloc not significant at $p \leqq .05$

Means joined by an underline are not different at $p \leqq .05$

Means are in ascending order, i.e. Lo $\rightarrow \mathrm{Hi}$

$\mathrm{Na}^{+}=$sodium; $\mathrm{K}^{+}=$potassium; $\mathrm{Cl}^{-}=$chloride; GOT = glutamic oxaloacetate transaminase; GPT = glutamic pyruvate transaminase. 
Appendix VIII. (Continued)

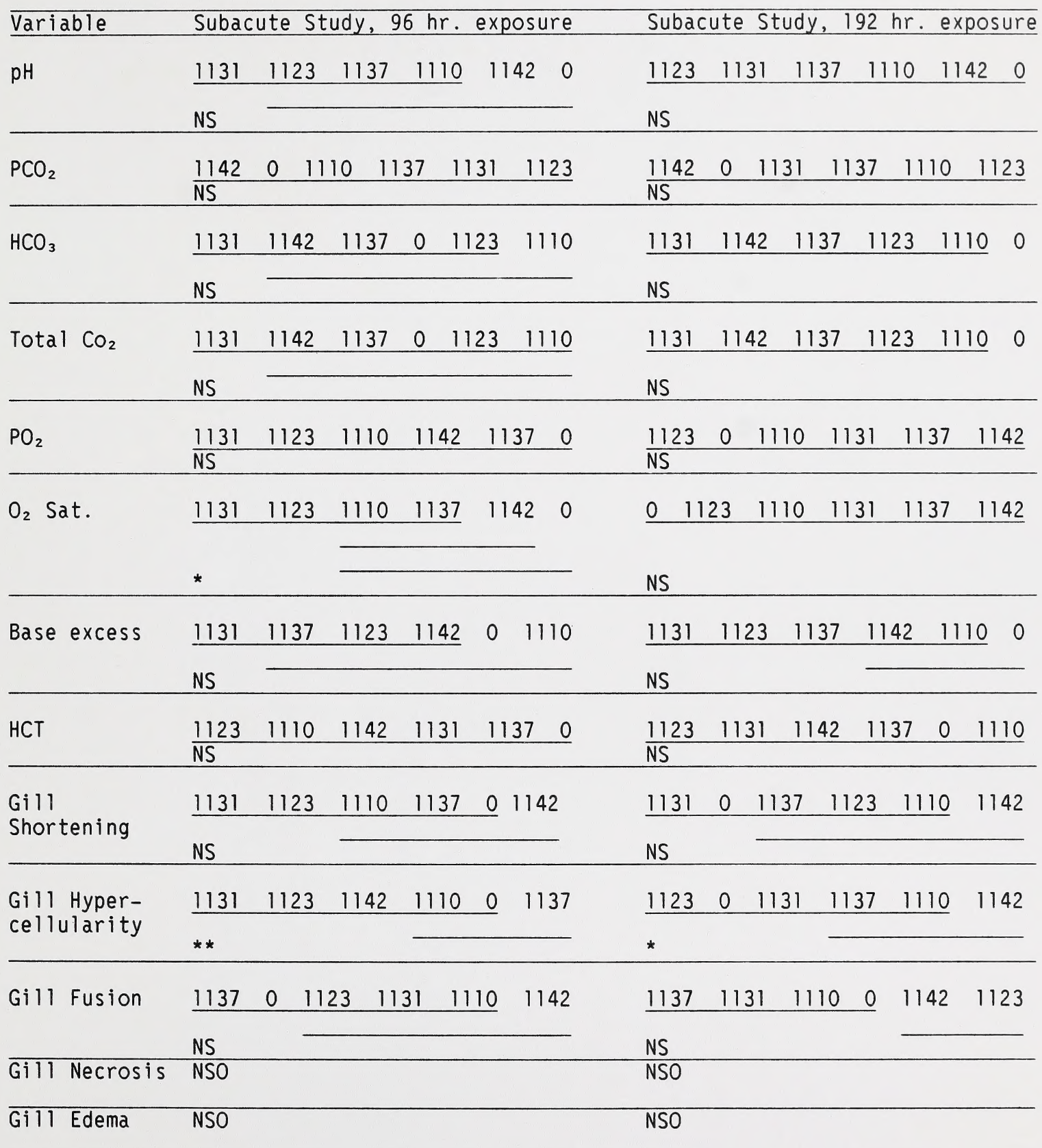



N.L.C. - B.N.C.

33286074999463 